\title{
Genotypic and phenotypic factors contributing to the development and progression of pneumoconiosis
}

Citation for published version (APA):

Zhai, R. (2005). Genotypic and phenotypic factors contributing to the development and progression of pneumoconiosis. [Doctoral Thesis, Maastricht University]. https://doi.org/10.26481/dis.20050623rz

Document status and date:

Published: 01/01/2005

DOI:

10.26481/dis.20050623rz

Document Version:

Publisher's PDF, also known as Version of record

\section{Please check the document version of this publication:}

- A submitted manuscript is the version of the article upon submission and before peer-review. There can be important differences between the submitted version and the official published version of record.

People interested in the research are advised to contact the author for the final version of the publication, or visit the DOI to the publisher's website.

- The final author version and the galley proof are versions of the publication after peer review.

- The final published version features the final layout of the paper including the volume, issue and page numbers.

Link to publication

\footnotetext{
General rights rights.

- You may freely distribute the URL identifying the publication in the public portal. please follow below link for the End User Agreement:

www.umlib.nl/taverne-license

Take down policy

If you believe that this document breaches copyright please contact us at:

repository@maastrichtuniversity.nl

providing details and we will investigate your claim.
}

Copyright and moral rights for the publications made accessible in the public portal are retained by the authors and/or other copyright owners and it is a condition of accessing publications that users recognise and abide by the legal requirements associated with these

- Users may download and print one copy of any publication from the public portal for the purpose of private study or research.

- You may not further distribute the material or use it for any profit-making activity or commercial gain

If the publication is distributed under the terms of Article $25 \mathrm{fa}$ of the Dutch Copyright Act, indicated by the "Taverne" license above, 


\section{Genotypic and phenotypic factors}

contributing to the development and progression of pneumoconiosis 
ISBN90 $5278470 \mathbb{1}$ 


\section{Genotypic and phenotypic factors contributing to the development and progression of pneumoconiosis}

\section{Proefschrift}

ter verkrijging van de graad van doctor aan de Universiteit Maastricht, op gezag van de Rector Magnificus, Prof.mr. G.P.M.F. Mols

volgens het besluit van het College van Decanen, in het openbaar te verdedigen op donderdag 23 juni 2005 om 14.00 uur

door

\section{Rihong Zhai}

geboren te Tianlin, Guangxi Province, PR China, op 19 maart 1959 


\section{Promotor:}

Prof.dr. J.C.S. Kleinjans

\section{Beoordelingscommissie:}

Prof.dr.ir. A. Schols (voorzitter)

Dr. B. Hoebee (RIVM)

Prof.dr. H. van Loveren

Prof.dr. R. Vlietinck

Dr. G-J. Wesseling

The studies presented in this thesis are financially supported by Guangxi Scientific Foundation, China (Grant No. 9817134); Scientific Foundation of Personnel Ministry of China; NIH Fogarty grant (TW00828), and NIH grant (ES00002 and CA74386), USA. 


\section{Contents}

Chapter 1 General introduction 1

Chapter 2 Polymorphisms in the promoter of the tumor necrosis 19

factor- $\alpha$ g gene in coal miners

Chapter 3 The $\mathrm{G}$ to $\mathrm{C}$ polymorphism at -174 of the interleukin-6

gene is rare in a Southern Chinese population

Chapter 4 Genetic Polymorphisms of MnSOD, GSTMI, GSTTI

and $O G G l$ in Coal Workers' Pneumoconiosis

Chapter 5 Serum levels of tumor necrosis factor-alpha (TNF- $\alpha$ ),

interleukin 6 (IL-6) and their soluble receptors in

coal workers' pneumoconiosis

Chapter 6 Differences in cellular and inflammatory cytokine

Profiles in the bronchoalveolar lavage fluid in

bagassosis and silicosis

Chapter 7

Metal content, hydroxyl radical generation, DNA damage

And cytokine release by different coal dusts: possible

correlation with prevalence of coal workers' pneumoconiosis

Chapter 8

Summary and general discussion

References

Acknowledgements

List of publication 



\section{Chapter 1 \\ General Introduction}

\subsection{Introduction}

Pneumoconiosis refers to a group of fibrotic lung diseases caused by the inhalation of inorganic (mineral) dusts (Parkes WR, 1994). The most commonly occurring types of pneumoconiosis are coal workers" pneumoconiosis (CWP) and silicosis, caused by exposure to coal mine dust and/or crystalline silica particles (Cullen MR, et al. 1990). CWP and silicosis have long been recognized as significant occupational lung disease. Although substantial knowledge about the means of their prevention, CWP and silicosis are still prevalent in industrialized countries (Redlich CA, 1996; Wagner GR, 1997; Pon MRL, 2003), and are an even greater problem in developing nations (Banks DE, 1998). Both diseases, which may have relatively long latency periods, are problematic in that treatment with corticosteroids and immunosuppressant, the usual approaches to therapy for fibrotic lung disease, is ineffective (Schwartz MI, et al. 1993).

Coalmine dust and silica are complex, naturally occurring minerals that are chemically and physically distinct. Moreover, the pathology of CWP and silicosis is dissimilar. However, the pathogenesis of these lesions and the major changes in pulmonary architecture, namely, the laying down of collagen in an interstitial location, appear to be similar. Both CWP and silicosis are characterized by a persistent inflammatory response and generation of pro-inflammatory and pro-fibrotic mediators (Mossman BT, et al. 1998; Roel RPF and Borm PJA, 1999).

\subsection{Coal mine dust exposure}

Coal is a fossil fuel mined in 50 countries throughout the world. It is the single largest fuel source for the generation of electricity worldwide. Top 5 major producers include China (1171Mt/year), USA (899Mt/year), India (310Mt/year), Australia (259Mt/year), and South Africa (225Mt/year) (WCI, 2003). There are two basic types of coal mining operation, surface mining and underground mining, producing distinctively different exposure variables and disease entities. Underground coall miners are at greatest risk of developing CWP than strip or surface miners because of the higher dust levels in the underground environment. In strip or surface mining, generated coal dust is diluted by outdoor air. However, rock-drilling operations associated with a greater risk of developing silicosis. 
It is estimated that about 7 million people work in coal mining industry in China. According to a data on the prevalence of pneumoconiosis from 1949 to 1986, obtained from a national epidemiological survey, and to national-wide annual data on newly reported cases of occupational diseases and deaths for the period 1987 to 1996, the cumulative number of CWP cases recorded in China between 1949 and the end of 1996 totaled 209, 239 (Zhou CQ, et al. 1997). The prevalence of pneumoconiosis was estimated to be about $6 \%$ among all coal miners (Wang and Christiani, 2003). In addition, it is estimated that about $20 \%$ of pneumoconiosis cases are not reported. The largest portion of unreported cases may come from small-scale enterprises, which there are poorly regulated working conditions and an incomplete reporting system (Zhou and Chen 1998). In the United States, approximately 200,000 workers are employed in coal mining industry. It is estimated that close to $9 \%$ of underground coal miners who work for 40 years in a $2 \mathrm{mg} / \mathrm{m}^{3}$ environment would develop pneumoconiosis. PMF would develop in 0.7\% (Attfield MD, 1992) In Western Europe, incidence of CWP has decreased since $1960 \mathrm{~s}$, due to a reduction in number of exposed subjects, improvements in occupational surveillance and to reduced exposure levels and duration (Parkes 1982; Cullen et al. 1990). However, from epidemiological studies, as well as from morbidity and mortality data in the general population, a rising trend in incidence and prevalence of CWP was observed in retired workers (Francois et al. 1988). Epidemiological studies in the UK demonstrated a higher prevalence of CWP in retired miners versus active workers (Soutar CA, 1987). At the end of 1986 in France, a total of 40,177 men were on the compensation register, while only $3 \%$ of them were still active (Gautrin et al. 1994).

\subsection{Physical and chemical properties of coal}

The predominant component of coal is carbon, formed by decomposition and compression of forest trees and related vegetation during the Carboniferous period, some 250 million years ago. Apart from carbon, coal dust may contain hydrogen, oxygen, nitrogen, trace metals, inorganic minerals, and crystalline silica. Trace metals can include boron, cadmium, copper, nickel, iron, antimony, lead, and zinc. Some of these trace elements can be cytotoxic and carcinogenic in experimental models. Common mineral and elemental contaminants are kaolin, mica, pyrite, titanium, calcite, sulfur, sodium, magnesium, and silica. The rank of coal. increases from peat to lignite, sub-bituminous to bituminous, and anthracite. As rank increases, the ratio of carbon to other chemicals and mineral contaminants increases. In general, anthracite coal mining has been associated with higher rates of pneumoconiosis than that found in bituminous mines (Ortmeyer CE, et al. 1973; Bennett JG, et al. 1979). 
Anthracite coalmine dust contains more surface free radicals than bituminous coal, which may explain its higher cytotoxicity and pathogenicity (Dalal NS, et al. 1995). In addition, anthracite has higher crystalline silica content than bituminous coal (Wallace WE, et al. 1994). However, experimental evidence suggests that silica particles from bituminous mines may be coated with clay, rendering them less active (Wallace WE, et al. 1994). Respirable coalmine dust has a relatively larger surface area due to its small aerodynamic size and porous nature. Organic aromatic compounds present in the coal atmosphere, such as benzene, methylene, phenol, and phenanthrene, can be absorbed onto the surface of coal mine dust and may affect its biological activity.

\subsection{Coal Workers' Pneumoconiosis (CWP)}

Inhalation of coal mine dust can lead to the development of several diseases including CWP, bronchitis, emphysema, Caplan syndrome, and silicosis (Kleinerman J, 1978). Coal miners typically develop one of two forms of disease patterns-simple CWP or complicated CWP. With chronic exposure, the milder form of CWP may become complicated CWP, with enlargement and profusion of lesions in the lung. Black lung is a legal term used to include CWP, bronchitis, emphysema, and silicosis when they are found in association with employment history in coal mines (Wagner GR, 1996).

The first case report on CWP was by Gregory (Gregory JC, 1831) in 1831 in a British coal miner. Initially coal dust was considered innocuous, and CWP was thought to be a variant of silicosis due to similarities in chest radiographs. This hypothesis was disproved by Collins and Gilchrist (Collins EL, Gilchrist JC, 1928). They studied the pathologic changes in the lungs of coal trimmers exposed to coal that was free of silica and showed that workers developed pneumoconiosis despite low silica exposure. Gough and Heppleston confirmed these findings and showed that the histological pulmonary lesions in coal trimmers were identical to those found in underground coal miners (Gough J, 1940; Heppleston AG, 1954). CWP was now clinically and pathologically distinguished from silicosis.

CWP is usually divided into two stages: simple pneumoconiosis (SP), in which fibrotic lesions remain limited, with radiological opacities smaller than $1 \mathrm{~cm}$, and progressive massive fibrosis (PMF), characterized by the development of a perifocal extensive fibrotic response of the lung and severe alterations in pulmonary function, with the size of radiological opacities exceed a diameter of $10 \mathrm{~mm}$. Simple CWP is characterized by the formation of black coal-dust macules centered around the respiratory bronchioles, mostly in the upper lobes of the lung. The macules range in size from 1 to $6 \mathrm{~mm}$ in diameter and irregular in size. Microscopically, 
macules contain coal dust-laden macrophages with a fine network of reticulin and some collagen fibers. Focal emphysema is a characteristic feature associated with these macules (Green FHY and Vallyathan V, 1998). These small coal dust- or carbonaceous material-laden pulmonary lesions have not been associated with pulmonary symptoms.

Progressive massive fibrosis (PMF) is a generic term common in many pneumoconiosis, including silicosis and CWP. In complicated CWP or PMF, lung function is compromised due to extensive fibrosis and emphysema. Progression of simple CWP to the more aggressive form of PMF is thoughtit to be associated with severe cumulative dust exposure, concentration of inorganic minerals and silica, impaired clearance, infections, and immunologic factors (Shennan DH et al. 1981; Douglas AN et al. 1986). There is a tendency for PMF to progress with or without further exposure (Shennan DH et al. 1981). Progression from simple CWP to PMF has been related to radiographic severity of disease, to coal mine dust exposure levels, and to total dust burden.

Microscopically, PMF lesions appear as coal dust-laden irregular or round, well-demarcated fibrotic masses of collagen bundles and haphazardly laid hyalinization or clusters of nodules. Necrosis is often associated with central cavitations, and cholesterol crystals are usually present. Vascular degenerative changes associated with bronchial and pulmonary arteries and lymphatic vessels are common in the lesions (Cotes JE, et al 1987).

\subsection{Silica Exposure}

High risk occupations of silica exposure include mining, sandblasting, surface drilling, stone cutting, construction, pottery making, sillica flour mill operation, and other occupations in which silica dust exposure occur (ATS Statement, 1997). In addition, environmental exposure to crystalline silica is common because of its abundance in soil. Silica can become airborne in arid, windy conditions or during agricultural, urban, and construction activities. In deed, lung fibrosis and pulmonary silica and mixed dust exposure have been observed in the lungs of farm animals and humans (Sherwin RP, et al. 1979).

\subsection{Pliysical and chemical properties of silica}

Silica is a group of naturally occurring minerals, existing in noncrystalline (amorphous) and crystalline forms (Ross, et al. 1993). Amorphous silica is much less toxic than crystalline silica although it is not biologically inert. The seven recognized crystalline silica, comprising silicon and oxygen ( $\mathrm{SiO} 2$ ) with trace amounts of $\mathrm{Al}, \mathrm{Fe}, \mathrm{Mn}, \mathrm{Ca}$, and $\mathrm{Na}$ in their structures, include quartz, cristobalite, moganite, tridymite, melanphlogite, coesite, and stishovite. These forms are also called "free 
silica" to distinguish them from the silicates, minerals containing silica bound to one or more metallic cations. Rocks such as granite, shale, and sandstones contain as much as $67 \%$ quartz, the most common crystalline silica; thus, mining, blasting, and construction activities result in significant exposure. Cristobalite is encountered in ceramic, refractory, and diatomaceous earth industries where processing of the crude materials involves heating to high temperatures (Weill $\mathrm{H}$ et al. 1994).

\subsection{Silicosis}

Silicosis is the pneumoconiosis resulting from the fibrotic reaction of lung tissue to the deposition of inhaled crystalline silica dust. There are several different clinical and pathologic varieties of silicosis, including simple (nodular) silicosis, acute silicosis (silicoproteinosis), complicated pneumoconiosis (PMF), and true diffuse interstitial fibrosis (Sillicosis and silicate Disease Committee, 1988). This review will concern itself only with simple silicosis since this is the condition that has generally been studied in experimental models.

Gross pathologic examination of lungs with simple silicosis shows discrete nodules that are extremely hard and vary in color from grey to blue to green if the exposure is to relatively pure silica, but they may be black (when silicosis develops in a coal miners) or red (when silicosis develops in a hematite miner). Microscopically early lesions are characterized by nodular to stellate aggregates of dust-laden macrophages arranged around a collagenous central region. With time, the central collagen becomes distinctly whorled and the relative number of inflammatory cells around the periphery decreases. Disease tends to be upper zonal, but the lower zones may be involved in severe cases. By definition the nodules of simple silicosis are no greater than $1 \mathrm{~mm}$ in maximum diameter; larger nodules are classified as complicated pneumoconiosis (PMF) (Weill HR, 1994).

Sillicosis is a major disabling occupational lung disease worldwide. During the period 1991 to 1995 , China recorded more than 500000 cases of sillicosis, with around 6000 new cases and more than 24000 deaths occurring each year mostly among older workers ( $\mathrm{Li} \mathrm{DH}, 1999)$. In the USA, it is estimated that approximately one million workers are occupationally exposed to free crystalline silica dusts, of whom some 59000 will eventually develop silicosis (Roznowski E, 1997). In Brazil, in the state of Minas Gerais alone more than 4500 workers have been diagnosed with silicosis (WHO, 2000). Among more than 17000 black South African gold miners who died of unnatural causes while actively employed in mines between 1975 and 1991, the prevalence of autopsy silicosis was $9.7 \%$. During the period of study, this prevalence rose of $12.8 \%$ in 1991, and it is expected to rise further (Murray J, 1996). 


\subsection{Mechanisms of pathogenesis of pneumoconiosis}

The pathology of human and rodent lung tissues after inhalation of mineral dusts has afforded knowledge of the cell types affected in the lung after deposition of minerals in the bronchiolar-alveolar dust region as well as the chronology of events leading to the development of fibrosis. In addition, experimental animal models and in vitro approaches have allowed elucidation of many of the molecular and functional changes in lung cells that may participate in the pathogenesis of pneumoconiosis. Although differing clinically and histologically, CWP and silicosis have a number of features in common in their pathophysiologies. All are characterized, in varying degrees, by lower respiratory tract inflammation, increased number of fibroblasts and fibroblast-like cells and excessive or abnormal, or both, connective tissue accumulation. (Castranova V, 1998; Schins RPF, 1999; Mossman BT 1998).

\subsubsection{Inflammatory process}

Pneumoconiosis is characterized by a continuous provocation of inflammatory response as indicated by the generation of proinflammatory and profibrotic mediators. After reaching the alveoli, mineral dusts are phagocytosed by alveolar macrophages (AM). Macrophages are damaged or activated and released cytotoxic oxidant or protease and inflammatory cytokines such as tumor necrosis factor (TNF- $\alpha_{\text {) }}$ ), interlukini-1(IL-1) interlukin-6 (IL-6). which provoke recruitment of inflammatory cells into the alveolar epithelial surface (initiation of alveolitis) (Schins RPF, 1999; Mossman BT 1998).

\subsubsection{Reactive oxygen generation}

It is becoming increasingly apparent that inflammatory tissue injury in the pathogenesis of pneumoconiosis is mediated by reactive oxygen species (ROS) (Brigham KL, 1980; Wallaert B, 1990; Balckford JAJ, 1997; Vallyathan $V, 1997$ ). These reactive radicals and oxidants may injure cells and tissue directly or via the formation of lipid peroxidation products such as 4-hydroxy-2-nonenal to enhance the inflammation through the activation of stress kinases (JNK, MAOK, p38) and redox sensitive transcription factors such as NF-capital KJE, MacedonianB and AP-1. oxidative stress and pro-inflammatory mediators can alter nuclear histone acetylation/decetylation allowing access for transcription factor DNA binding leading to enhanced pro-inflammatory genes expression in various lung cells ( Rahman I, 2001). This may occur by the activation of certain transcription factors, such as transcription factor kB (NF-kB), a ubiquitous transcription factor and pleiotropic regulator of numerous genes involved in the immune and inflammatory response (Baeuerle PA, 1994; Sun Y, 1996; Rahman I, 1998; Vallyathan V, 1998). 


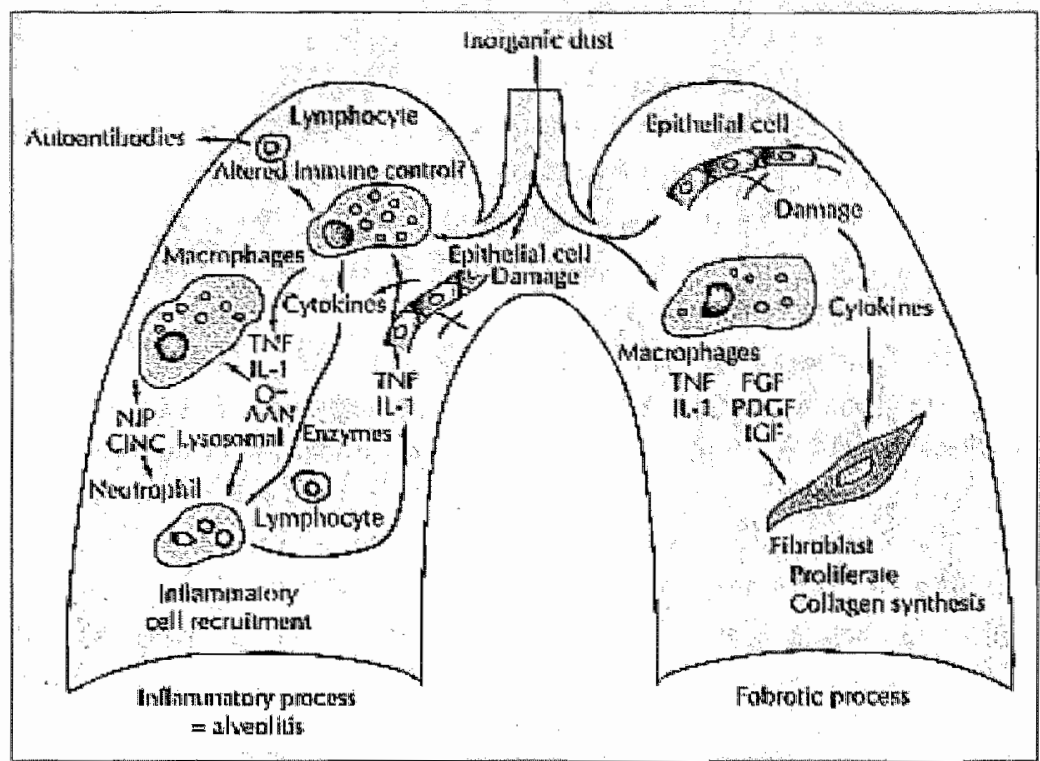

Figure 1. The chronic inflammation of the lung (alveolitis) and resulting fibrosis are main mechanisms of pneumoconiosis. 1. Inflammation process: inhaled dust particles are phagocytosed by alveolar macrophages (AM). AM are damaged and activated to release cytotoxic $O$ or lysosomal enzymes and inflammatory cytokines such as TNF$\alpha, I L-1$, MIP, which recruit inflammatory cells into the alveoli (initiation of alveolitis). Epithelial cells are also damaged, and they release inflammatory cytokines. Immune regulatory activity of $A M$ is altered and may induce autoimmune lung injury. AM, lymphocytes, and neutrophils are the main cells forming alveolitis. "These activated inflammatory cells damaged the pulmonary architecture and from the basis of fibrotic scar. 2. Fibrotic process: Following the inflammatory process, the reparative and fibrotic phase emerges. Growth factors (TNF, IL-1, FGF, PDGF, and IGF) stimulate the recruitment and proliof type II pneumocytes, and fibroblasts and induce overproduction of fibronectin and collagen, resulting in the development of fibrosis (Fujimura N, 2000).

Two mechanisms by which mineral dust exposure causes formation of ROS in vitro have been proposed, i.e. (1) the formation of ROS by intrinsic properties of the particles, i.e. non-cellular mechanisms, and (2) the excessive formation of ROS by the oxidative burst of macrophages. and neutrophils activated during particle phagocytosis and persistent inflammation. 
It has been proved that mineral dusts can spontaneously catalyze the formation of free radicals mediated by surface iron as a primary source of toxicity (Fubini and Mollo, 1995). The crushing of crystalline silica and coal can generate the free radicals $\mathrm{Si}$ and $\mathrm{SiO}^{\circ}$ at cleavage zones, that may react with water to yield $\mathrm{OH}$ (Vallyathan $\mathrm{V}, 1988$; Shi X, 1988; Dalal NS, 1995). Fenton-reaction type formation of hydroxyl radicals was found to be positively correlated to iron content of coal dust (Dalal NS, 1995). Transition metal ions present on the surface of silica or within biological milieus promote this reaction.

Another pathway of free radical generation by mineral dusts occurs via an oxidative burst when fibers are phagocytized by alveolar macrophages (AMs) or other cell types, including alveolar epithelial cells and fibroblasts (Churg A, 1996). During the process of phagocytosis of inhaled particulate, $\mathrm{O}_{2}{ }^{-}$is generated and its dismutation results in the production of $\mathrm{H}_{2} \mathrm{O}_{2}$. In the presence of transition metal irons, such as ferrous iron or cuprous irons, $\mathrm{H}_{2} \mathrm{O}_{2}$ is converted to the potent oxidizing radical, $\mathrm{OH}$, through the Fenton reaction. There is overwhelming evidence that inhalation of toxic occupational and environmental pollutants leads to excessive in vitro and in vivo generation of .OH radicals during phagocytosis (Vallyathan V, 1992; Kaddiska MB, 1997; Castranova V, 1996). Such an overwhelming burst of ROS generation subsequently triggers a severe inflammatory cellular reaction resulting in additional generation of ROS. Alveolar macrophages of dust-exposed subjects produced increased amount of oxygen radicals compared to nonexposed subjects (Voisin C, 1985; Rom WN, 1987)

\subsubsection{Stimulation of Inflammatory Cytokine Release}

Cytokines are polypeptide mediators produced by a variety of cell types that exert their biological functions through specific cell surface receptors that transmit intracellular signals (Rochester CL, 1993). Cytokines play a major role in immune responses, inflammatory and fibrotic processes. With respect to inflammation, proinflammatory cytokines are classified into those involved in Thl responses, such as interleukin (IL) $-1,-6,-12$ and TNF $\alpha$, and those involved in Th2 responses including IL-4, IL-5, IL10, IL-13 and TGF- $\beta$. Several of these cytokines are also involved in down-regulation of inflammatory pathway such as IL-6, IL-10 and the IL-1 receptor antagonist (RA).

Inflammatory reactions are an essential component of the body defense mechanisms that under normal circumstances are tightly regulated and of limited duration. However, when the stimulus is persistent or non- limiting, excessive or chronic production of 
Table 1. Silica or coalmine dust-induced activation of oxidant release from alveolar macrophages

\begin{tabular}{|c|c|c|c|}
\hline Response & silica & coal dust & references \\
\hline \multicolumn{4}{|l|}{ In vitro studies } \\
\hline Superoxide anion & +1 & NR & Castronowa V, 1994 \\
\hline Hydrogen peroxide & ++ & $N R$ & Castronova $\mathrm{V}, 1994$ \\
\hline $\begin{array}{l}\text { Chemiluminescence } \\
\text { In vivo animal studies }\end{array}$ & $+4+$ & NR & Castronova $\mathrm{V}, 1994$ \\
\hline Hydrogen peroxide & +4 & NR & Castronowa V, 1994 \\
\hline Chemiluminescence & + & + & $\begin{array}{l}\text { Castronowa V, 1985; } \\
\text { Castronova V, } 1996\end{array}$ \\
\hline Nitric oxide & +4 & + & $\begin{array}{l}\text { Black ford JA, } 1997 \\
\text { Castronova V, } 1996\end{array}$ \\
\hline \multicolumn{4}{|c|}{ Human studies-patients with CWP or silicosis } \\
\hline Superoxide anion & $+t$ & + & $\begin{array}{l}\text { Wallaert B, } 1990 \\
\text { Roni WM, } 1987\end{array}$ \\
\hline Hydrogen peroxide & +4 & NR & Rom WM, 1987 \\
\hline Chemilluminescence & ++ & + & $\begin{array}{l}\text { Castronova } \mathrm{V}, 1998 ; \\
\text { Goodman } \mathrm{GB}, 1992\end{array}$ \\
\hline Nitric oxide & + & + & Castronova V, 1998 \\
\hline
\end{tabular}

Abbreviations and symbols: + , significant response; ++ , greater response than $+; \mathrm{NR}$, response has not been reported.

inflammatory mediators, including cytokines, occurs resulting in disease. This chronic inflammation is characterized temporally by a slower onset and more protracted course than acute inflammation, and morphologically by abundant lymphocyte and monocyte infiltration.

Subsequently, fibroblast proliferation, fibrosis and frequent microvascular proliferation may ensue. Chronic inflammation may initiate disease or exacerbate pre-existing ones. Specific examples of occupational or environmental diseases where chronic inflammation has been shown to contribute to pathogenesis include chronic obstructive pulmonary disease (COPD) (Sakao S, 2001), hypersensitivity pneumonitis (Schaaf BM, 2001), silicosis (Yucesoy B, 2001), sarcoidosis (Seitzer U, 1997), chronic beryllium disease (CBD) (Maier LA, 2001), occupational asthma (Noguchi E, 2001), alcohol- and chemical-induced hepatitis (Takamatsu $M, 2000$ ), allergic and irritant contact dermatitis (Allen MH, 2000) (Table 1).

cytokines such as TNF- $\alpha$, IL-1, which provoke recruitment of inflammatory cells into the alveolar wall and alveolar epithelial surface (initiation of alveolitis). AMs are the main cells forming alveolitis, although lymphocytes and neutrophils are also involved. These activated inflammatory cells damage the pulmonary architecture and form the basis of fibrotic scars (Schins RPF, 1999; Mossman BT 1998). A list of inflammatory cytokines and chemokines produced in response to silica or 
coal dust exposure is given in Table 2 .

Table 2. Silica or coal mine dust-induced stimulation of cytokine and chemokine secretion from lung cells

\begin{tabular}{|c|c|c|c|}
\hline Response : & silica & coal mine dust & References \\
\hline \multicolumn{4}{|l|}{ In vitro studies } \\
\hline Plateletactivating factor & + & + & Kang JH, 1991 \\
\hline Leukotriene $\mathrm{B}_{4}$ & +1 & + & Driscoll KE, 1990 \\
\hline Prostaglandin $\mathrm{E}_{2}$ & $\mathrm{NR}$ & + & Kuhn DC: 1992 \\
\hline Thromboxane $A_{2}$ & $\mathbb{N R}$ & + & Kuhn DC, 1992 \\
\hline TNF $-\alpha$ & $+t$ & + & $\begin{array}{l}\text { Driscall KE, } 1990 \text { (1); } \\
\text { Gosset P, } 1991\end{array}$ \\
\hline $1 \mathrm{~L}-1$ & $+t$ & + & Kang $\mathrm{JH}_{3} 1992$ \\
\hline $\mathrm{HL}-6$ & NR & + & Gosset $\mathbb{P}, 1991$ \\
\hline \multicolumn{4}{|l|}{ In vivo animal studies } \\
\hline Leukotriene $\mathrm{B}_{4}$ & + & + & $\begin{array}{l}\text { Henderson RF, } \\
1991 \text {; Kuhn DC, } 1990\end{array}$ \\
\hline Prostaglandin $\mathrm{E}_{2}$ & + & NR & Henderson RF, 1991 \\
\hline Thromboxane $\mathrm{A}_{2}$ & NR & + & Kuhn DC, 1990 \\
\hline $\mathrm{TNF}=\alpha$ & ++ & NR & Driscoll KE, 1990 (2) \\
\hline $\mathrm{IL}-1$ & + & $N \mathbb{R}$ & Driscoll KE, $1990(2)$ \\
\hline \multicolumn{4}{|c|}{ Macrophage inflammatory protein } \\
\hline & +4 & NR & Driscoll KE, 1993 \\
\hline \multicolumn{4}{|c|}{ Human studies-patients with CWP or sillicosis } \\
\hline TNF $\sim \alpha$ & NR & + & Lassalle P, 1990 \\
\hline$\| \mathrm{L}-1$ & NR & + & Lassalle P, 1990 \\
\hline \multicolumn{4}{|c|}{ Monocyte chemoatractant peptide-1 } \\
\hline & NR & + & Boitelle A, 1995 \\
\hline IL-6 & NR & * & Vanhee D, 1993 \\
\hline
\end{tabular}

Abbreviations and symbols: + , significant response; +4 , greater response than + ; $N R$, response has not been reported.

\subsubsection{Fibrotic process}

The inflammatory process is followed by a reparative phase in which growth factors stimulate the recruitment and proliferation of type II pneumocytes, fibroblasts, fibronectin, and collagen, resulting in the development of fibrosis (Schins RPF, 1999; Mossman BT 1998).

A number of cytokines produced by alveolar macrophages have regulatory effects on fibroblast growth and/or collagen synthesis. When the balance between fibrotic and antifibrotic mediators shifts, pulmonary fibrosis can develop. IL-1 (Prostlethwaite AE, 1984), TNF- $\alpha$ (Vilcek J, 1986), platelet-derived growth factor (PDGF) (Reist RH, 1991), fibronectin, alveolar macrophage-derived growth factor (Bitterman PB, 1986), and type 1 insulinlike growth factor (Vanhee $D, 1994$ ) have been 
reported to increase fibroblast proliferation. PDGF and fibronectin are competence factors, whereas alveolar macrophage-derived growth factor is a progression factor for proliferation of fibroblasts. $\| \mathrm{L}-1$ has also been described as a direct stimulant of collagen production (Goldring MB, 1986). TNF- $\alpha$ is not only a direct proliferative agent for fibroblasts but also stimulates the secretion of PDGF in vitro (Haijar KA, 1987). A critical role of TNF- $\alpha$ in pulmonary fibrosis is demonstrated by the fact that anti-TNF- $\alpha$ significantly decreased sillica-induced pulmonary fibrosis in a mouse model (Piguet PF, 1990).

In contrast, IL-6 exhibits anti-fibrotic activity (Kelley J, 1990). Prostaglandin $E_{2}$ and transforming growth factor beta (TGF- $\beta$ ) exhibit a depressive effect on cell growth (Reist RH, 1991; Vanhee D, 1994). However, under certain conditions, TGF- $\beta$ can stimulate collagen synthesis in vitro (Dean DC, 1988).

The effects of silica or coal dust exposure on alveolar macrophage production of cytokines that regulate fibrogenesis are listed in Table 2.

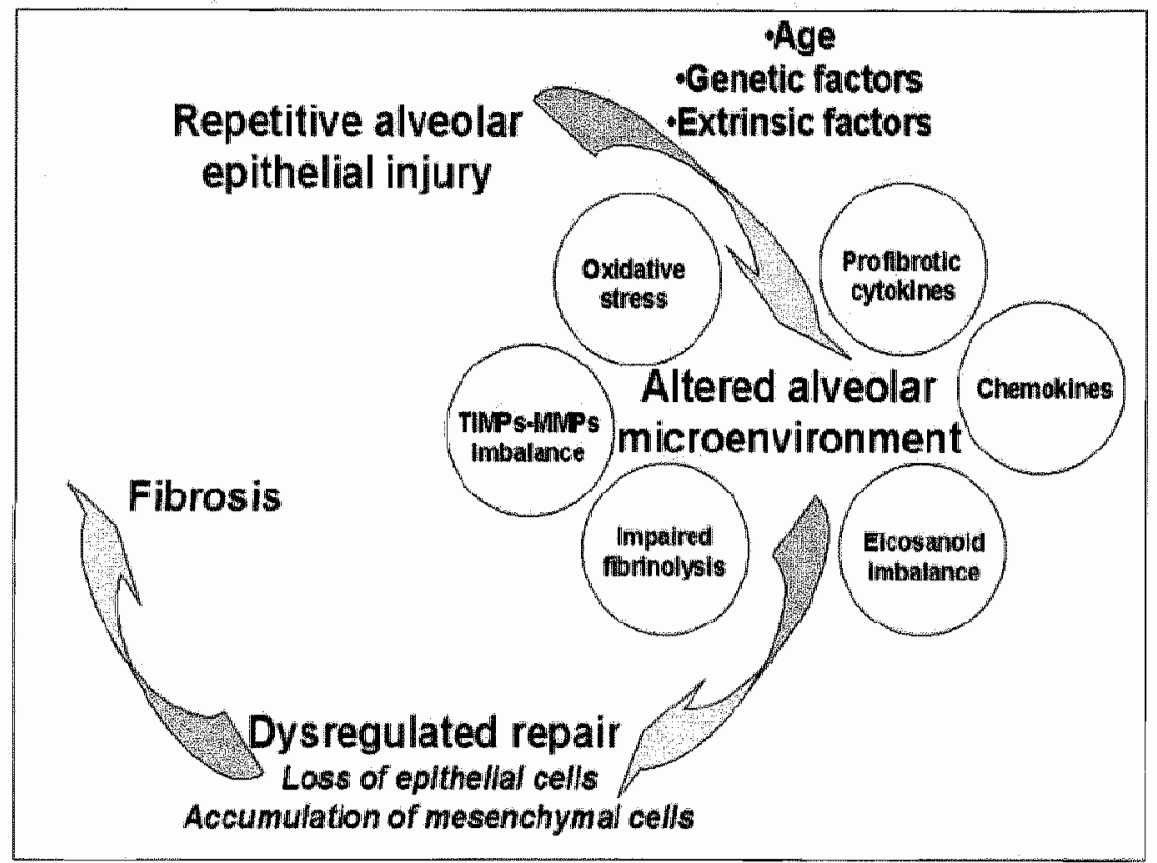

Figure 2. Progressive pulmonary fibrosis results from dynamic alterations in the alveolar microenvironment that eventually promote loss of alveolar epithelial cells and accumulation of activated fibroblasts/myofibroblasts. Such alterations include the presence or activation of profibrotic cytokines, growth factors, and chemokines; a state of elevated oxidative stress; overproduction of TIMPS relative to MMPs; impaired fibronolysis; and eicosanoid imbalance with increased production of profibrotic leukotrienes (Thannickal VJ, et al. 2004). 
Although exposure has been reported to stimulate both fibrogenic and antifibrogenic factors, it appears the balance shifts toward fibrotic stimuli. For example, TNF- $\alpha$, type 1 insulinlike growth factor, and PDGF all increase as simple CWP progresses to PMF.

\subsection{Genetic Risk Factors for Pneumoconiosis}

Despite the clear association of dust exposure and pneumoconiosis, there remains marked inter-individual variation in the response to dust exposure even when the level of exposure is similar. It has been known that pneumoconiosis occurs in only a small proportion of miners equally exposed to mineral dusts, suggesting that genetic factors are likely to be important in determining which miners are at risk developing pneumoconiosis. Furthermore, some patients develop pneumoconiosis at an early age, again indicating that genetic factors may determine the progression of pneumoconiosis. Bleomycin is a chemotherapeutic agent used in the treatment of germ-line tumours and Hodkins lymphoma. An estimated $3-5 \%$ of patients develop pulmonary fibrosis (White DA, 1987), implying some subjects appear more prone to the development of fibrosis. The importance of genetic factors in the development of lung fibrosis is also confirmed by animal models in which a strain-dependent variability in the response to bleomycin-induced pulmonary fibrosis has been observed. For example, the C57BL/6J mice exhibit high sensitivity to bleomycin-induced lung fibrosis whereas the BALB/cBY strain demonstrated a resistant phenotype (Schrier DJ, 1983). The level of TGF $\beta$ 1. and interleukin- $1 \beta$ expression is higher in the sensitive strain. Interestingly, the sensitive (C57BL/6J) strain also exhibit an enhanced fibrotic response to silica injection associated with increase in TNF$\alpha$ expression in bronchoalveolar lavage fluid (Ohtsuka Y, 1995).

\subsubsection{Identification of Susceptibility Genes}

Complex genetic diseases, such as CWP, are caused by the interaction of environmental factors and genetic susceptibility. Positional cloning has been used to identify the genes for many Mendelian disorders, and has also proved successful in localizing multiple regions of interest in complex diseases, such as hypertension (Soubrier F, 1995) and diabetes mellitus (Davies JL, 1994). The positional cloning approach uses multiple-affected families, and compares the inheritance of the disease to the inheritance of genetic markers known chromosomal location. If a genetic marker is consistently co-inherited with the disease, then it is inferred that the disease gene lies close to that marker on the same chromosome. Additional markers from the region are used to progressively refine the localization, until the gene can be identified. 
The power of positional cloning studies is reduced by polygenic inheritance, genetic heterogeneity and interactions with environmental factors. Mineral dust is such an important risk factor for pneumoconiosis that it is impossible to match families for the amount and duration of dust exposure. In addition, most patients with pneumoconiosis are not diagnosed until late in life so that extensive family studies are not possible.

For these reasons, positional cloning is difficult to apply to genes involved in the pathogenesis of pneumoconiosis. A more promising approach has been to select genes that are likely to be involved in the pathogenesis of pneumoconiosis and then to study polymorphisms in these candidate genes and relate these to the occurrence, severity, and progression of the disease (Stanford AJ, 1997).

For candidate gene to be a viable candidate in one disease a number of criteria must be fulfilled. Firstly, the gene product must be a protein likely to be relevant to disease pathophysiology. Secondly, the gene must contain either within its coding or regulatory sequence variations which produce functional differences in the amount or structure of the protein. Thirdly, these structural variants must be related to the disease in association studies. Finally, ideally one would want to see linkage of the chromosomal region containing the candidate gene to markers of the pneumoconiosis phenotype in genome screening (Hall IP, 1999).

Candidate SNPs may be assessed for association with specific disease states by utilizing a number of epidemiologic study designs including cohort, case-control, case-only and family based designs. Both cohort and case-control studies can be utilized to investigate association between SNPs and disease, between exposure and disease, and the joint interaction between exposure, genotype and disease. However, cohort studies generally require a larger sample size to detect interactions that do casecontrol studies. Case-control studies, when carefully designed and the disease incidence is low, can provide essentially all the information that is obtained with respect to cohort designs with fewer subjects (Clayton and McKeigue, 2001).

\subsubsection{Genetic Polymorphisms and Disease}

Polymorphisms are stable, inter-individual allelic variants that, relative to mutations, are present in high frequencies in the population, i.e., $>1 \%$ ). These common variants usually involve a substitution of a single nucleotide base pair (single nucleotide polymorphisms, SNPs) in the coding region of a gene, which results in coding for a different amino acid so that protein structure and function may be altered. Polymorphisms 


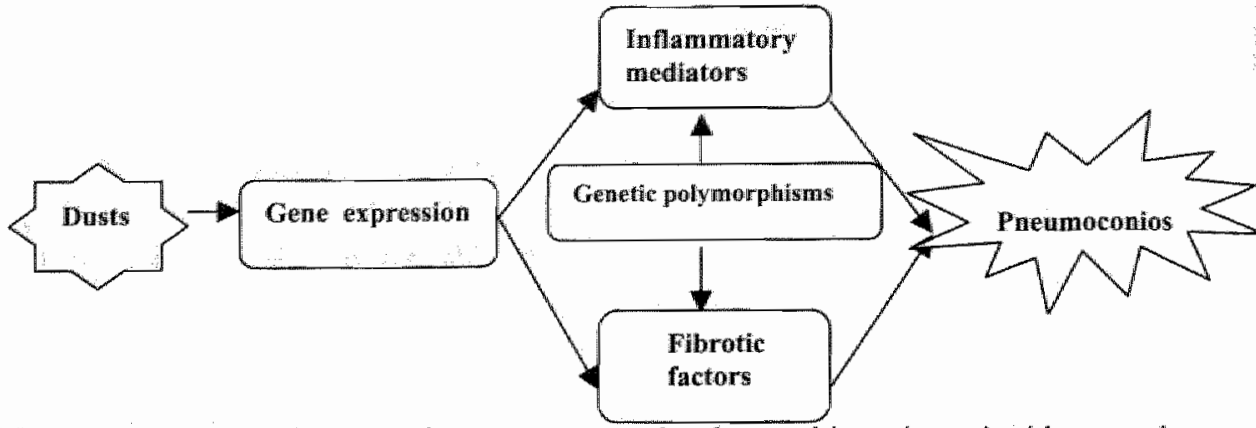

Figure 3. Interactions between dust exposure and polymorphisms in antioxidants and inflammatory cytokines genes may contribute to the pathogenesis of pneumoconiosis.

may also occur in the $5^{\prime}$-promoter regions of genes and, if this occurs at the site of binding of a transcription factor, this may result in increased or decreased expression of the gene, or the substitution may allow binding of new transcription factors resulting in altered control of gene expression. Repeat sequences of nucleotide bases may also occur and some people have increased numbers of these repeats so that this can affect transcriptional control of the gene. Finally, there may be mutations in the 3 - -untranslated region of the gene and this may affect the stability of mRNA and thus the amount of protein translated. These polymorphisms may be associated with altered susceptibility to disease, to disease severity, and to the response to treatment. It is likely that the coincidence of multiple polymorphisms will be an important mechanism for determining differences in the phenotypic expression of polygenic diseases (Figure 3).

\subsubsection{Genetic Polymorphisms of cytokines}

Polymorphisms in cytokine genes have been reported to contribute to the recognized stable inter-individual variation in the level of cytokine production rates (Pociot F, 1997; Perrey C, 1998). Inter-individual differences in spontaneous as well as stimulated production of IL-6 and TNF- $\alpha$ (Schins RPF and Borm PJA, 1995; Fishman D, 1998) support the possibility that pneumoconiosis severity are related to the genetic to the host to produce these proteins. Examples of cytokine polymorphisms which have been implicated to modify chronic inflammatory diseases, often associated with environmental and occupational exposures are presented in Table 3, 4 .

\subsubsection{Human Leukocyte antigen locus}

Human genetic studies in pulmonary fibrosis to date have been centered on known genetic loci with a high degree of polymorphism, and those involved in the inflammatory response. The Human Leukocyte Antigen 
Table 3. Example of associations between cytokine polymorphisms and occupational diseases.

\begin{tabular}{|c|c|c|}
\hline Disease & Cytokine polymorphism & References \\
\hline $\begin{array}{l}\text { Alcohol and } \\
\text { chemical-induced } \\
\text { hepatitis }\end{array}$ & $\begin{array}{l}\text { TNFa }(-308), \quad(-238) ; \quad \text { IL-1 } \\
(+3953), \quad(-511)\end{array}$ & $\begin{array}{l}\text { Yee LJ, 2000; Takamatsu } \\
\mathrm{M}, 2000\end{array}$ \\
\hline $\begin{array}{lr}\text { Allergic } & \text { and } \\
\text { irritant } & \text { contact } \\
\text { dermatitis } & \end{array}$ & TNF $\alpha(-308)$ & Allen MH, 2000 \\
\hline Asthma & $\begin{array}{l}\text { IL-4 intron } 2, \text { IL-4RA, IL-13 (- } \\
1111) \text {, TGF- } \beta \text { (-509) TNF } \alpha \text { - } \\
308)\end{array}$ & $\begin{array}{l}\text { Noguchi E, 2001; Howard } \\
\text { TD, 2002; Moffatt MF, } \\
\text { 1997; Pulleyn LJ, } 2001\end{array}$ \\
\hline $\begin{array}{l}\text { Chemical-induced } \\
\text { neurotoxicity }\end{array}$ & IL- $1 \alpha(-899)$, TNF $\alpha(-308)$ & $\begin{array}{l}\text { Rebeck GW, 2000; Boin F, } \\
2001\end{array}$ \\
\hline $\begin{array}{l}\text { Chronic beryllium } \\
\text { disease (CBD) }\end{array}$ & TNFa $(-308)$ & Maier LA, 2001 \\
\hline $\begin{array}{l}\text { Chronic } \\
\text { obstructive } \\
\text { pulmonary disease } \\
\text { (COPD) }\end{array}$ & TNFa $(-308)$ & Sakao S, 2001 \\
\hline $\begin{array}{l}\text { Farmer's } \\
\text { disease }\end{array}$ & TNFa $(-308)$ & Schaaf BM, 2001 \\
\hline Sarcoidosis & TNFa $(-308)$ & Seilzer U, 1997 \\
\hline
\end{tabular}

(HLA) residing on chromosome 6, is the most studied in this respect. Various authors have attempted to established linkage with an HLA type but the results are not conclusive and are often conflicting. Some studies found that HLA genes are associated with pneumoconiosis development (Table 5), while others found no association of HLA genotypes with Pneumoconiosis (Heise ER, 1979; Kreiss K, 1989)

\subsubsection{Genetic variation of antioxidants}

The increased oxidative stress observed in patients with pneumoconiosis is due to exogenous oxidants from dusts, but also from reactive oxygen species generated endogenously (Vallyathan V, 1998). Several enzymes are involved in the generation of reactive oxygen species, and several antioxidants counteract their effects in the airways. Genetic polymorphisms of these enzymes and proteins may therefore affect the degree of oxidative stress that occurs in response to activating stimuli. An overview of the antioxidant enzymes, their properties, their known polymorphisms, and where known, the corresponding phenotype, as well as results from epidemiological association studies are summarized in Table 6. 
Table 4. Example of cytokine SNPs found to affect expression levels and modify disease.

\begin{tabular}{|c|c|c|}
\hline Cytokine & Polymorphic locus & References \\
\hline $1 \mathrm{~L}-\mathrm{Ia}$ & $-899,+4845$ & $\begin{array}{lrr}\text { Shirodaria } & \mathrm{S}, & 2000 \\
\text { McDowell } & \mathrm{TL}, & 1995 ; \\
\text { Jouxenne } \mathrm{P}, 1999\end{array}$ \\
\hline$\pi \mathrm{L}-1 \beta$ & $-511,+3953$ & $\begin{array}{l}\text { Kornman KS, 1997; Pociot } \\
\text { F, 1992; Bioque G, } 1995\end{array}$ \\
\hline IL-IRA & VNTR。 +2018 & $\begin{array}{l}\text { Yocesoy B, 2001; Whyte } \\
\text { M, 2000, } \\
\text { Santtila S, 1998; Tarlow } \\
\text { JK, } 1993\end{array}$ \\
\hline IL-4 & $-590,+33$ & $\begin{array}{lcc}\text { Noquchi } & \mathrm{E}, & 2001 ; \\
\text { Chouchane } & \mathrm{L}_{3} & 1999 ; \\
\text { Cantagrel A, } 1999 & \\
\end{array}$ \\
\hline IL-6 & $-174,-572$ & $\begin{array}{l}\text { Fishman } \begin{array}{c}\mathrm{D} \\
\text { Humphries }\end{array} \mathrm{SE}, 2001 \\
\text { Heg; }\end{array}$ \\
\hline IL -10 & $-627,-1082,-819,-592$ & $\begin{array}{l}\text { Mitchell SA, 2001; Borish } \\
\text { L, 1996; } \\
\text { Hobbs K, 1988; Lim S, } \\
1998\end{array}$ \\
\hline IL-13 & $-1055,-1111$ & $\begin{array}{l}\text { Howard TD, 2002; } \\
\text { Chouchane L, } 1999 \\
\end{array}$ \\
\hline TNF $\alpha$ & $-308,-238$ & $\begin{array}{c}\text { Yocesoy B, 2001; Seitzer } \\
\text { U, 1997; } \\
\text { Moffatt MF, 1997; Maier } \\
\text { LA, 2001; } \\
\text { Huang SL, } 1997 \\
\end{array}$ \\
\hline TGFß1 & $509,10,25$ & Pulleyn LJ, 200I \\
\hline
\end{tabular}

\subsubsection{Coal ranks and pneumoconiosis}

Coal rank is defined as the extent to which the organic materials have matured during geological time. The four major coal types ranked in order of increasing heat value are: lignite $<$ sub bituminous $<$ bituminous $<$ anthracite. Coal rank can be roughly estimated by the carbon content in the coal, molar ratio of carbon/hydrogen $(\mathrm{C} / \mathrm{H})$, heat value, volatile materials, or moisture (Meyers RA. 1982). Despite comparable exposures to coal dust, there remains marked regional variation in the prevalences of CWP even though. For example, the first round of the US National Study of CWP, which was completed in 1971, has examined a total of 9076 miners from 29 bituminous and 2 anthracite mines (Morgan WKC, 1973). The average exposure concentration in the US mines during that period was $3 \mathrm{mg} / \mathrm{m}^{3}$. It was found that $41 \%$ of the eastern Pennsylvania 
anthracite miners had SP and a further $14 \%$ had PMF, but the conparable figures for bituminous miners in Colorado and Utah were $4 \%$ and $0.4 \%$ (Morgan WKC, 1973; Attfield MD, 1992c). Follow-up studies at the same mines (in 1972-1975, 1977-1981, and 1985-1988) had shown that this regional difference persisted with greater risk of CWP in eastern coal mimers (Pennsylvania and West Virginia) than in western coal miners (Utah and Colorado) (Attfield MD, 1995). In France, coal miners of Provene never had CWP $(0 \%)$, while the prevalence of CWP in coal miners of Nord Pas De Calais was 24\% (Amoudru C. 1987). In United Kingdom, a detailed study of

Table 5. Human leukocyte antigen (HLA) association with
pneumoconiosis

\begin{tabular}{llcl} 
Disease & HLA allele association with susceptibility & References \\
\hline CWP & Bw21, Bw45, B5, DRw53 & Walmer MM, 1979; Darke C,
\end{tabular}

Silicosis A29, Aw19, B44, DR8, Bw54, DR4 Kreiss K, 1989; Honda K, 1988; Honda K, 1993

Table 6. Genes related to oxidative stress and their polymorphisms

\begin{tabular}{llc}
\hline Gene & Nucleotide change & \multicolumn{1}{c}{ Ref. } \\
\hline MnSOD & Ala $^{9} /$ Val & Ambrosone CB, 1999 \\
CAT & G $>$ A-int4; T Tel 358 & Wen JK, 1990; Hirono A, 1995 \\
GPX1 & T $>$ C2; C $>$ T593 & Moscow JA, 1992 \\
GSTM1 & Gene deletion & Seidegard J, 1988 \\
GSTP & A $>$ G 313; C $>$ T 341 & Ahmad H, 1990 \\
GSTT & Gene deletion & Lo HW, 1997 \\
NQO1 & C $>$ T 609 & Traver RD, 1997 \\
OGG1 & Ser/Cys & Hardie LJ, 2000 \\
\hline
\end{tabular}

eight mines has shown that one mine with an exposure concentration of 9.1 $\mathrm{mg} / \mathrm{m}^{3}$ (pre-1970 dust concentrations) reported $2.4 \%$ of $\mathrm{CWP}$ and another mine with only $3.6 \mathrm{mg} / \mathrm{m}^{3}$ reported $16.6 \%$ of CWP (Crawford NP, 1982). Coal rank was found to play a rolle: risk increases with the coal ranks (Miller $\mathrm{BG}, 1985$ ). Coal dusts with different ranks showed varying cytotoxic capacities (Schulz HM, 1997). It has been suggested that the physicochemical characteristics of the coal mined may be responsible for regional differences in the prevalence of CWP. 


\subsection{Aim and outline of this thesis}

As discussed above, physicochemical properties of the dusts, dustinduced release of $\mathbb{R O S}$ and cytokines are clearly involved in the pathogenesis of pneumoconiosis. It is also clear that genetic factors modify the response to environmental stimuli in humans. However, the genetic factors contributing to the development of pneumoconiosis have been largely unexplored. Little progression was made in attempting to define the interaction between genotypes and phenotypes in the pathogenesis of pneumoconiosis. Therefore, the aim of this thesis is to characterize genetic and phenotypic factors contributing to the development or progression of mineral dust-induced pneumoconiosis.

\section{The outline of the thesis is as follows:}

Chapter 2: The relationship between polymorphisms of TNF- $\alpha$ promoter and CWP development was studied in a group of ex-coal miners.

Chapter 3: The possibility that polymorphisms at position -174 of the promoter of the IL-6 gene are involved in the pathogenesis of CWP was explored in 259 retired coal miners.

Chapter 4: The association between genetic polymorphisms of antioxidant genes and susceptibility to CWP was analyzed in a group of coal miners with documented coal mine dust exposure histories.

Chapter 5: The levels of systemic TNF- $\alpha_{2}$ IL-6, and their soluble receptors as biomarkers CWP were evaluated in 182 coal miners who had similar dust exposure histories.

Chapter 6: A comparison of cellular and cytokine features in the BAL fluids between patients with silicosis and bagassosis was made to better understand the pathogenesis of bagassosis and silicosis.

Chapter 7: This chapter investigates metal composition, ROS generation, cytokine release capacity and oxidative DNA-damage by coal samples with different ranks, in order to identify coal dust characteristics that may contribute to the prevalence of CWP.

Chapter 8: discusses the overall results of the preceding chapters, summarizes the findings, and makes recommendations for future research. 


\section{Chapter 2}

\section{Polymorphisms in the Promoter of the Tumor}

\section{Necrosis Factor- $\alpha$ Gene in Coal Miners}

Rihong Zhai, "Manon Jetten, 'Roell P.F.Schins, "Henk Franssen, " and Paul J. A.

$$
\text { Borm, }
$$

1. Department of Health Risk Analysis and Toxicology, Maastricht Universily, The Netherlands; 2. Department of Molecular Biology, Agricultural University, Wageningen, The Netherlands

Published in: American Journal of Industrial Medicine, 1998; 34: 318-324. 


\section{Abstract}

Tumor necrosis factor- $\alpha\left(\mathrm{TNF}_{-}-\alpha\right)$ is recognized as a central mediator of mineral dust-induced lung fibrosis, and genetic polymorphisms of the TNF promoter have been reported to influence levels of TNF production. To assess whether polymorphisms within the TNF promoter gene are associated with susceptibility to coal workers' pneumoconiosis (CWP), the DAN of 78 coal miners was typed for G-to-A transitions at positions -238 and -308 . Our results show that frequency of A-308 genotype (T2) is significantly overpresented in coal miners with CWP $(50 \%)$, as compared with miners without CWP (25\%) and controls (29\%). After correction for cumulative dust exposure and smoking, the A-308 transition genotype is still associated with the presence of CWP $(\mathrm{OR}=3.0,95 \% \mathrm{CI}=1.0-9.0)$. Both $\mathrm{A}-238$ and A308 transition genotypes were related to TNF release from endotoxinstimulated blood monocytes; only the A-238 transition and not the A-308 transition was associated to coal dust-induced TNF release. In summary, this study shows that the A-308 transition is related to CWP, but this relation is not paralleled by a different TNF release in this genotype. A larger number of patients coupled to frequent TNF release are required to evaluate genotype screening to estimate individual health risks for effects of coal mine dust exposure. 


\section{Introduction}

It is unknown why coall workers" pneumoconiosis (CWP) occurs in only a small proportion of individuals equally exposed to coal mine dust. Cytokines and in particular tumor necrosis factor- $\alpha$ (TNF) [Piguet et al, 1990; Gauldie et all., 1993; Vanhee et al., 1995], are of primary importance in this response. Previously, we reported that spontaneous and coal dust-stimulated TNF release from peripheral blood monocytes was increased in coal miners with early CWP [Borm et al., 1998]. In a 5-year follow-up study of the same group of subjects, we confirmed the above findings and found that miners who showed abnormally high release of TNF stimulated by coal dust had an increased risk of progression in CWP [Schins and Borm, 1995]. In line with these observations in monocytes, spontaneous TNF release from alveolar macrophages has been shown to be higher in subjects with progressive massive fibrosis than in individuals with simple CWP and nonexposed controls [Lasalle et al., 1990]. Increased release of TNF was also found in alveolar and peritoneal macrophages of rats exposed to silica [Driscoll et al.1990; Mohr et al., 1991]. In addition. elevated $\mathrm{mRNA}$ levels of TNF have been observed in lungs of pneumoconiosis patients [Vanhee et al., 1995] and in mouse models of pneumoconiosis, administration of anti-TNF could prevent lung fibrosis [Piguet et al., 1990]

Since inter-individual differences in spontaneous as well as stimulatory production of TNF seem stable in time [Jacob et al., 1990; Pociot et al., 1993; Schins and Borm, 1995], this supports testing of the possibility that CWP is related to the genetic propensity of the host to produce TNF protein. The gene encoding for TNF is located within the class III region of the major histocompatibility complex [Carrol et al., 1987]. Two single-base polymorphisms have been identified at positions -308 and -238 of the human TNF gene promoter [Wilson et al., 1993; D'Alfonso and Momigliano, 1994], with the mutant allele containing A instead of $\mathrm{G}$ at each site. Recent studies indicated that individual differences in TNF production can partly be linked to polymorphic markers in this region [Wilson et al., 1994; Westendorp et al., 1997]. Moreover, silica has been shown to up-regulate the TNF promoter region, resulting in the release of TNF protein from the cells [Savici et al., 1.994]. Considering the role of TNF in the pathogenesis of CWP and the association of TNF production to genetic variants in TNF-promoter gene, we hypothesized that polymorphisms in the TNF promoter region may be implicated in the pathogenesis of coal dust-induced pneumoconiosis. Therefore, in the present study, we investigated G-to-A transition polymorphisms at -238 and -308 of the TNF promoter gene in the same cohort of coal miners in a recent, 10-year follow-up. In addition, this 
enabled us to investigate the link between these genotypes and previously described differences [Schins and Borm, 1995] in coal mine dust-induced TNF release.

\section{Materials and methods}

Subjects

Ex-coal miners $(\mathrm{n}=78$ ) from the Belgian coal mining industry "Kempense Steenkoolmijnen" involved in previous studies in 1987 and 1992 [Schins and Borm, 1995] participated in the present study [1997] as a 10-year follow-up. All participants were asked to complete a validated questionnaire covering smoking history (in pack-years) and respiratory symptoms. Chest radiographs were taken according the ECSC (European Community for Steel and Coal) criteria $(46 \times 46 \mathrm{~cm}$, posterior to anterior, maximal inspiration at $1.5 \mathrm{-m}$ distance and $70 \mathrm{kV}$ ) and subjects provided a blood sample $(10 \mathrm{ml})$ for genotyping. Healthy controls for genotype frequencies $(n=56)$ were randomly selected from the general population in the same area, enrolled in a smoking-cessation program. Scoring of the chest radiographs was achieved by consensus classification of chest radiographs by three radiologists according to ILO criteria. Miners with ILO classification of $0 / 0$ were classified as "healthy coal workers," while miners with 0/1 were considered "CWP subjects" for two reasons: (1) previous studies in this cohort showed that TNF release was significantly increased in miners in early stages of CWP (starting from ILO score 0/1) upon stimulation with coal dust and a gradual return to control TNF release along with increasing stage of CWP [Borm et al., 1988; Schins and Borm, 1995], and (2) radiographic category $=0 / 1$ has been shown to have good agreement with pathologic lesions in CWP as well as in silicosis [Hnizdo et al., 1993; Vallyathan et al., 1996]. Individual dust exposure histories were expressed as: (1) time worked underground, (2) time since first occupational exposure, and (3) cumulative dust exposure calculated as described previously [Schins and Borm, 1995].

\section{TNF-Promorer Gene polymorphisms}

Venous blood samples were collected in anticoagulated tubes with EDTA; red blood cells were lysed with 3 vol of lyses buffer $\left(155 \mathrm{mM} \mathrm{NH}_{4} \mathrm{Cl}\right.$, $10 \mathrm{mM} \mathrm{KHCO} 3.10 \mathrm{mM}$ EDTA, pH7.4; Merck, Darmstadt, Germany). The cell pellets after centrifugation (white blood cells) were stored at $-80^{\circ} \mathrm{C}$ until analysis. Genomic DNA was extracted from peripheral blood leukocytes of all subjects using DNA isolation kit (Gentra Systems, Minneapolis, $\mathrm{MN}$ ) according to the manufacturer's instructions. The analysis of the TNF-promoter polymorphisms was performed by polymerase chain reaction (PCR) amplification (using 5'AGGCAATAGGTTTTGAGGGCCAT3' and 5 
ACACTCCCCATCCTCCCGGCT 3 ' as the primers) (GLBCO-BRL, Glasgow, UK) [Wilson et al., 1992]. A 117-base pair (bp) fragment of the TNF promoter spanning the TNF-238 to -308 sites was generated in a 50 $\mathrm{ml}$ reaction mixture. This reaction mixture contained $100 \mathrm{mM}$ of each dNTP, $50 \mathrm{ng}$ of each primer, $100 \mathrm{ng}$ genomic DNA, $1 \times 10$ reaction buffer, and 1.5 U Taq polymerase (GLBCO-BRL). Amplifications were carried out for 35 cycles at $95^{\circ} \mathrm{C}, 60^{\circ} \mathrm{C}$, and $72^{\circ} \mathrm{C}$ for $15 \mathrm{sec}, 30 \mathrm{sec}$, and $30 \mathrm{sec}$, respectively. Detection of the fragment (117 bp) amplified by PCR was made by electrophoresis on a $2 \%$ agarose gel. Restriction enzyme digestion with NcoI (ICN, OH) of the PCR product (117 bp) and subsequent electrophoresis on a $10 \%$ polyacrylamide gell discriminated between two alleles: Tl (G-308) showed two fragments of 97 and $20 \mathrm{bp}$, while its homologue (T2) was undigested and resulted in a single band of $117 \mathrm{bp}$. Heterozygous individuals (T2) were detected by the presence of all three fragments $(97,20$, and $117 \mathrm{bp})$. The biallelic polymorphism at position -238 was detected by NLaIV (Amersham, Japan) restriction enzyme digestion of the amplified $117 \mathrm{bp}$ and subsequent size separation by electrophoresis on a $10 \%$ polyacrylamide gel. Allele TNF-G $\left(\mathrm{G}^{-238}\right)$ yielded three fragments of 50,47 , and $20 \mathrm{bp}$, while the allele TNF-A ( $\mathrm{A}^{\text {- }}$ ${ }^{238}$ ) showed two bands of $70 \mathrm{bp}$ and $47 \mathrm{bp}$. An example of the gel electrophoresis of these different genotypes is shown in Figure 1.

\section{TNF Phenotype}

TNF release from blood monocytes had been measured in 1992 at the 5year follow-up in 105 coal miners, of which 66 were also involved in the current follow-up. Since TNF release was shown to be stable over time [Schins and Borm, 1995], repeated measurements were considered superfluous. In short, TNF release was measured by enzyme-linked immunosorbent assay (ELISA) in supernatants of adherent monocytes $\left(5 \times 10^{6}\right)$ incubated with coal mine dust $(5 \mathrm{mg} / \mathrm{ml})$, silica $(0.5 \mathrm{mg} / \mathrm{ml})$, Escherichia coli 0111B4 lipopolysaccharide (LPS) endotoxin (3 and $1,000 \mathrm{ng} / \mathrm{ml}$ ) or without stimulant for $18 \mathrm{hr}$ at $37^{\circ} \mathrm{C}$ and $5 \% \mathrm{CO}_{2}[\mathrm{Borm}$ et al., 1988].

\section{Statistical Methods}

Data are presented as number and/or percentage of the genotypes and allele frequencies for each transition polymorphism. Data were analyzed using the $\chi^{2}$ test to compare the proportions of TNF genotypes among coal miners with CWP, coal workers without CWP and controls. Logistic regression was used to estimate the relation between radiographic evidence of CWP and genotype, adjusting for the potential effects of other variables, such as smoking status, age, and cumulative dust exposure. All p-values given are two-tailed. Student's t-test was used to 
calculate differences of TNF production, measured in 1992 [Schins and Borm, 1995], between G-to-A transition polymorphism groups. Correlations between release of TNF and dust exposure, age, smoking, TNF genotype were evaluated by multiple linear regression. All statistical evaluations were made using SPSS for Windows 7.0 (SPSS Inc., Chicago, IL).

\section{Results}

Study Population

A total of 78 ex-coal miners involved in previous TNF studies [Borm et al., 1988. Schins and Borm, 1995] attended our follow-up examinations (Table I). No selection bias was found for age, smoking, or dust exposure histories, as compared with cohorts in the previous studies in 1987 $(n=154)$ or $1992(n=104)$. The average exposure duration for all subjects studied is more than 20 years. All miners had left active mining since 1991 and had not been subjected to dust exposure for at least 6 years and maximal 10 years. Within this group, $18(23 \%)$ miners had radiographic evidence of CWP $(1 / 0: 4 ; 1 / 1: 3 ; 1 / 2: 4 ; 2 / 1: 3 ; 2 / 2: 2 ; 2 / 3: 1$ and $3 / 2: 1)$. The remaining 60 members of the cohort $(77 \%)$ had no discernible radiographic abnormalities $(0 / 0)$.

Table 1. Age, smoking, and exposure of the coal miners with different genotypes in the TNF promoter region*

\begin{tabular}{lccccc}
\hline Parameter & $\begin{array}{c}\mathrm{G}-308 \\
(\mathrm{n}=54)\end{array}$ & $\begin{array}{c}\mathrm{A}-308 \\
(\mathrm{n}=24)\end{array}$ & $\begin{array}{c}\mathrm{G}-238 \\
(\mathrm{n}=11)\end{array}$ & $\begin{array}{c}\mathrm{A}-238 \\
(\mathrm{n}=67)\end{array}$ & $\begin{array}{c}\text { Total group } \\
(\mathrm{n}=78)\end{array}$ \\
\hline Age (yr) & $51.2(4.9)$ & $52.5(5.2)$ & $51.9(5.0)$ & $59.9(4.7)$ & $51.6(4.7)$ \\
Smoking (pack-years) & $108.4(119)$ & $139.6(126)$ & $112.6(1.5)$ & $148.5(155)$ & $117.7(121)$ \\
Years underground & $22.4(4.3)$ & $23.1(4.5)$ & $22.4(4.4)$ & $23.7(4.2)$ & $22.6(4.4)$ \\
Years since first exposure & $33.8(5.4)$ & $33.6(5.9)$ & $33.4(5.7)$ & $35.7(4.0)$ & $33.7(5.5)$ \\
Cum dust exposure (gh/ $\left.\mathrm{m}^{3}\right)$ & $94.2(5.4)$ & $84.8(6.6)$ & $92.2(6.0)$ & $86.2(4.1)$ & $91.4(5.8)$ \\
\hline Values are mean and standard deviation (in parentheses)
\end{tabular}

\section{TNF Genotypes and Radiographic Abnormalities}

The distribution of TNF genotypes in coal miners and controls is shown in Table II. In the control and the healthy miners population, the allele frequencies of the -238 and -308 polymorphisms were comparable to those reported by others [Wilson et al., 1992; D'Alfonso and Momigliano, 1994; Westendorp et al., 1997; Bouma et al., 1996]. Among the miners, 54 subjects were found to be $\mathrm{G}^{308}$ carriers, while 24 had the corresponding G-to-A polymorphism ( $\mathrm{A}^{3}{ }^{308}$ ). In individuals with the $\mathrm{T} 2$ allele, one subject was homozygous (AA-308), while all others $(n=23)$ were heterozygous (AG-308.). Among those with radiographic evidence Of CWP, 50\% were found to be the A-308 genotype and this was significantly higher than in miners without $\mathrm{CWP}\left(\chi^{2}=4.1 ; \mathrm{p}<0.05\right)$, and 
therefore overrepresented among individuals with radiographic abnormalities within this cohort. No significant differences in distribution of the -238 genotypes were detected among the groups under study.

Table 2. Distribution of the G-to-A transition polymorphs in the TNF promoter region at $-\mathbf{3 0 8}$ and -238 in coal miners with and without CWP and Controls

\begin{tabular}{llll}
\hline & $\begin{array}{l}\text { Miners with } \\
\text { CWP }(\mathrm{n}=18)\end{array}$ & $\begin{array}{l}\text { Miners without } \\
\text { CWP }(\mathrm{n}=60)\end{array}$ & $\begin{array}{l}\text { Controls } \\
(\mathrm{n}=56)\end{array}$ \\
\hline & & & \\
G-308(TNF1) & $9(50 \%)$ & $45(75 \%)$ & $44(79 \%)$ \\
A-308(TNF2) & $9(50 \%)^{*}$ & $15(25 \%)$ & $12(21 \%)$ \\
G-238(TNF-G) & $15(83 \%)$ & $52(87 \%)$ & $49(88 \%)$ \\
A-238(TNF-A) & $3(17 \%)$ & $8(13 \%)$ & $7(12 \%)$ \\
\hline
\end{tabular}

"Significantly different from miners without CWP $\left(\chi^{2}=4.1, p<0.05\right)$, and controls $\left(x^{2}=4.2, p<\right.$ $0.05)$

\section{Possible Confounders}

To ensure that the higher prevalence of coal dust-induced radiographic abnormalities in the miners with the $\mathrm{T} 2$ genotype was not confounded by systematic differences in the dust exposure, age or smoking, we examined these variables in each genotype. There were no significant differences in age, several surrogate measures of exposure and smoking habits between the different genotypes (Table I). Second, a multivariate logistic model was constructed in which ILO-defined CWP $(>0 / 0)$ was used as the dependent variable, and age, time since first exposure, years exposed, cumulative dust exposure, and smoking (pack-years) were entered as independent variables. This was conducted stepwise to determine which of the surrogate exposure variables might contribute significantly to the prevalence of radiographic abnormalities from coal dust exposure. In this analysis both cumulative dust exposure $(\beta=0.0151, P=0.012)$ and the presence of the $A-308$ transition genotype $(\beta=1.40, P=0.04)$ were significantly associated with radiographic abnormalities (total model $x^{2}=10.97, \quad P=0.004$ ), whereas for the -238 genotypes, there was no association between genotypes and radiographic abnormalities.

\section{Monocyte TNF Production and TNF Polymorphisms}

The relation between the TNF promoter polymorphisms and TNF phenotype was tested using in vitro TNF release measured at 5-year follow-up [Schins and Borm, 1995] from nonstimulated monocytes of the same subjects $(n=66)$ or monocytes stimulated with endotoxin, silica, or coal dust. Mean levels of TNF release of subjects with the G-to-A 
transition at -308 were significantly higher in the wild-type (G-308), as compared with the A-308 both for spontaneous and LPS $(1,000 \mathrm{ng} / \mathrm{mi})$ induced release (Table III). By contrast, the wild-type polymorph at -238 showed a lower LPS-induced TNF release $(4.6 \mathrm{ng} / \mathrm{ml})$, compared with the A-238 genotype $(8.73 \mathrm{ng} / \mathrm{ml})$. Coal dust-induced TNF release was not related to -308 genotypes but was significantly higher in miners with the Gi-238 phenotype $(2.0 \mathrm{ng} / \mathrm{ml})$, as compared with the A-238 genotype (1.0 $\mathrm{ng} / \mathrm{mll}$ ).

Table 3. In vitro release of TNF from monocytes induced by LPS and particulate in the various genotype groups among 66 ex-coal miners*

Monocyte TNF-release $(\mathbf{n g} / \mathbf{m l})$

\begin{tabular}{lccccc} 
& & Silica & CMD & LPS & LPS \\
\hline Genotypes & Unstimullated & $(\mathbf{0 . 5 g / m})$ & $(\mathbf{5 ~ m g} / \mathbf{m l})$ & $(1,000 \mathbf{~ n g} / \mathbf{m l l})$ & $(\mathbf{3} \mathbf{~ n g} / \mathbf{m l})$ \\
\hline G-308 & $0.22(0.29)$ & $0.85(0.78)$ & $1.98(1.35)$ & $5.50(5.50)$ & $202(2.23)$ \\
A-308 & $0.11(0.12)^{*}$ & $0.67(0.97)$ & $1.73(1.79)$ & $2.68(2.01)^{\mathrm{a}}$ & $1.64(1.77)$ \\
G-238 & $0.20(0.27)$ & $0.83(0.83)$ & $2.00(1.40)$ & $4.60(4.77)$ & $2.00(2.06)$ \\
A-238 & $0.21(0.32)$ & $0.59(0.75)$ & $1.02(0.40)^{\mathrm{a}}$ & $8.73(8.40)^{\mathrm{a}}$ & $3.61(2.75)$ \\
\hline
\end{tabular}

Values are mean and standard deviation (in parentheses).

* Significartly different from the wild-type (G) genotype, $p<0.05$ (Student t-test).

However, only high-dose $(1,000 \mathrm{ng} / \mathrm{ml})$ LPS-induced TNF release was still related to TNF promoter genotypes $(\mathrm{G} / \mathrm{A}-238$ : $\mathrm{P}=0.044 ; \mathrm{G} / \mathrm{A}$ 308: $\mathrm{P}=0.085)$ in a multiple linear regression relating TNF release to genotypes, age, smoking (pack-years), and cumulative dust exposure. Combination of different genotypes in haplotypes $\left(\mathrm{G}^{-308}+\mathrm{G}^{-238}, \mathrm{G}^{-308}+\mathrm{A}^{-}\right.$ $\left.{ }^{238}, \mathrm{~A}^{-308}+\mathrm{G}^{-238}, \mathrm{~A}^{-308}+\mathrm{A}^{-238}\right)$ did not show a significant relation between any TNF haplotype and TNF release (data not shown).

\section{DISCUSSION}

Previously we showed that the TNF phenotype is related to the presence and progression of CWP [Schins and Borm, 1995]. In this study, we investigated whether genetic variance in the TNF promoter gene was related to CWP and TNF Phenotype. Although the number of cases with CWP $(n=18)$ is small, we observed a significantly higher frequency of the A-308 genotype in coal miners with radiographic evidence of CWP as compared with control miners and references. This difference was not 
confounded by coal dust exposure, smoking status and age. No association between $-238 \mathrm{G}$-to-A transition genotypes and CWP was found. In all our groups, the allele frequencies of both polymorphisms are comparable to those reported by others for Caucasian populations [D' Alfonso and Momigliano, 1994; Westendorp et al., 1997]. Several studies have explored the role of polymorphisms in the TNF-promoter gene in rheumatoid arthritis [Brinkman et al., 1996]. Multiple sclerosis [Huizinga et al., 1997] and non-insulin-dependent diabetes [Hamann et al., 1995]. MS patients with TNF-G showed a more aggressive disease course compared with cases with TNF-A, explained by a higher production of TNF upon endotoxin but in non-insulin-dependent diabetes no increase prevalence of -238 polymorphisms was found [Hamann et al., 1995]. Recently, findings in fatal infectious diseases [Westendorp et al., 1997] showed that whole blood TNF production was a risk factor for fatal outcome of meningococcal disease. However, only $60 \%$ of the variation in TNF production was genetically determined and transition polymorphisms were not associated with the outcome of infection. The latter study illustrates the importance of concomitant phenotype analysis in studies of genetic susceptibility.

Since the polymorphisms under study are in a region that controls TNF transcription, we also investigated the relation between the G-to-A transitions and TNF release from blood monocytes in a subgroup $(n=66)$ of the same subjects. In our hands, only LPS (1,000ng.ml)-induced TNF release was found to be related to both the -238 genotype and the -308 transition genotype, although the relation with the -238 G-to-A transition was strongest. Spontaneous and coal dust-induced TNF release did not sustain more rigid statistical testing using multiple linear regression. The G-to-A mutation at -308 , when linked to a chloramphenicol acety]transferase receptor gene, is known to cause a six-to sevenfold increase in constitutive and PMA-induced transcription rate compared with wild-type TNF1 [Wilson et al., 1994]. In our cohort, wild-type $G^{.308}$ showed a higher TNF release compared with the G-to-A transition genotype. On the other hand, reports from functional analysis by Pociot et al. [1995] showed that monocyte TNF production induced by LPS was not related to TNF-238 alleles, while we showed a significantly higher LPS rellease in the $A^{-238}$ is within a $Y$ box that is believed to play a role in the baseline expression of MHC class II promoter rather than in their inducibility [Fong et al., 1994]. As a previous study has identified a TNF repressor site between base pairs -254 and -230 in the promoter [Sariban et al., 1988 ], the polymorphism at -238 could be associated with an increase in TNF transcription. Several possibilities can explain the discrepancies between our findings and the above data. First, transcriptional regulation of TNF is probably under complex homeostatic control, as for the TNF 
receptor [de Kossodo et al., 1994]. One allele may be less sensitive to homeostatic downregulation and thus may allow transcription to proceed for longer causing more persistent production of TNF. Further studies are required to examine the effects of the different promoter alleles on transcription [Brinkman et al., 1996]. Second, considerable control of TNF production is present at the posttranscriptional [de Kossodo ef al., 1994; Han et al., 1990] and translational levels [Schins et al., 1996; Westendorp et al., 1997]. Third, although TNF release was shown to be stable in time [Schins and Borm, 1995], and we used measurements on one occasion in 1992, probably multiple measurements of TNF over time would have given a more accurate estimation of mean TNF secretion in each subject. Finally, dust-induced monocyte TNF release is somewhat different from whole TNF release, which is used as phenotype in most studies. In our hands, the best correlation ( $\mathrm{r}=0.87$ ) between whole blood TNF release and monocyte TNF release was obtained using 6-hr incubation for whole blood and $18 \mathrm{hr}$ for monocytes [Schins et al., 1996]. The main reasons that could explain the different kinetics are the presence of soluble regulating mediators in plasma (i.e., LPS-binding protein, soluble TNF receptors), cytokine networks between different blood cells and differences in cell-particle interaction between both in vitro systems [Borm et al., 1996].

Apart from these explanations, the influence of several HLA alleles on TNF secretion cannot be excluded [Jacob et al., 1990; Pociot et al., 1993]. In humans, production of TNF has been found to correlate with HLA-DR alleles [Molvig et al., 1988]. The DR2 ${ }^{+}$genotype was associated with low TNF response, whereas DR $3^{+}$and $\mathrm{DR} 4^{+}$genotypes were related to high levels of TNF production [Jacob et al., 1990]. It has also been reported that TNF-A-positive individuals were either DR3 or DR7 positive, while TNF2 was also related to HLA-DR haplotypes [Bonma al, 1996]. HLA haplotypes that include DR3 are also known to be associated with a wide range of autoimmune diseases, including insulin-dependent diabetes mellitus, systemic lupus erythematosus, and celiac disease [Garcia-Merino et al., 1996]. Several studies have been reported in coal workers with CWP, but no studies in coal workers are available linking allelic polymorphs to TNF release. In German coal workers, the frequency of DR8 was elevated in miners with CWP, whereas the frequency of DRI and DR52 was reduced in miners without CWP [Rihs et al., 1994]. Studies among Japanese subjects with silicosis indicated that HLA-B54-DR4-DR53 are positive and HLA-B52-DR4DR2 negative linkage disequilibrium with silicosis respectively [Honda et al., 1993]. However, there is conflicting evidence that the TNF gene promoter region is linked to MHC HLA class's variation [Wilson et al., 1993; McGuire et al., 1994; Garcia- Moreno, 1996]. The association of A 
308 with CWP might be linked to a linkage disequilibrium to HLA alleles, but we have no data on other alleles and, for the TNF promoter, our data do not allow such evaluation, as only one subject with the $\mathrm{T} 2$ allele was homozygous (AA-308), while others were heterozygous (AG-308).

In summary, our study shows an increased presence of the $A^{-308}$ transition genotype in the TNF promoter in ex-coal miners with mild CWP. Because of the relatively small size of our study group, more patients need to be investigated to confirm this finding and study the value of genotype testing in individual risk of CWP. Currently, there is no evidence to use genotype screening for selecting individuals at risk of the pulmonary effects of coal mine dust and other inorganic dusts. 


\section{Chapter 3}

\section{The $G$ to $C$ Polymorphism at -174 of the}

\section{interleukin-6 gene is rare in a Southern Chinese}

\section{Population}

Rihong Zhai ${ }^{1}$, Geoffrey Liu', Chaomin Yang ${ }^{2}$, Chuonhong Huang, Chuanren $\mathrm{Wu}^{4}$ and David C. Christiani ${ }^{1}$

'Occupational Health Progam, Department of: Environmental Health, Harvard School of Public Health, Boston, Massachusetts, USA;

${ }^{2}$ Division of Pneumoconiosis, Guangxi Institute of Occupational Health, Namning, China:

${ }^{3}$ Division of Occupational Health, Guangxi Anti-epidenic and Health Center, Nanning, China.

${ }^{4}$ General Hospital of Heshan Coal Mine Co., Heshan, Guangxi, China.

Published in Parmacogenetics, 2001; 11: 699-701. 


\begin{abstract}
Interleukin-6 is thought to be involved in the pathogenesis of coal workers" pneumoconiosis. Recently, a functional $\mathrm{G}$ to $\mathrm{C}$ polymorphism at position -174 of the promoter of the IL-6 gene has been described. We examined the -174 polymorphisms in 259 retired Chinese men from Guangxi province (all retired coal miners). Only one GC heterozygous and no $\mathrm{CC}$ homozygous variants were found. Our results suggest that the frequency of the $\mathrm{C}$ allele in this Chinese population is lower than in Caucasian and east Indian populations.
\end{abstract}




\section{Introduction}

Interleukin-6 (IL-6) is a multifunctional cytokine that mediates inflammatory and stress-induced responses, and has been implicated in the pathogenesis of coal workers' pneumoconiosis (CWP). The release of IL-6 from human macrophages is increased in response to coal dust exposure (Gosset et al., 1991). IL-6 expression and secretion is greater in the lungs of coal miners with CWP than in control subjects (Vanhee et al., 1995), The increased expression of IL-6 by macrophages has been confirmed in other models of occupational disease, such as asbestosis (Perkins et al., 1993). IL-6 is implicated in fibro tic responses because it can induce collagen synthesis in vitro and inhibit collagen degradation (Bienkowski et al., 1995). Recently, it was reported that IL-6 levels were increased in the broncho-alveolar lavage fluid (BALF) of CWP patients (Vallyathan et al., 2000).

The gene encoding for IL-6 is located on chromosome 7. Recently, a polymorphism in the 5 'flanking (promoter) region of this IL-6 gene (at position -174) has been reported. Subjects with the $G$ allele had higher plasma IL-6 levels compared with C allele carriers (Fishman et al., 1998). To explore the possibility that this IL-6 polymorphism is involved in the pathogenesis of CWP, we originally investigated this promoter polymorphism in a group of Chinese coal miners with CWP and compared them with controls consisting of retired coal miners without CWP. A secondary objective was to describe the population frequency of this polymorphism in the Chinese population.

\section{Materials and methods}

For this study, eligible participants consisted of retired coal miners from the Heshan Coal Mine Company (located in Guangxi Province, Southern China). The miners from this company, all men of Southern Chinese descent (self-reported to be native to Guangxi, and of Han descent, the primary ethnic group in China), consisted of radiographically diagnosed CWP patients $(n=99)$ and control subjects (retired miners without CWP, $\mathrm{n}=160$ ). This study was approved by the Human Subjects Committee of Heshan General Hospital and written informed consent was obtained from each participant.

Genomic DNA was extracted from clotted blood using the puregene DNA isolation kit (Gentra Systems, Minneapolis, Minnesota, USA). A polymerase chain reaction (PCR)-based technique was used and negative control subjects without DNA template were included with each reaction. The hotstar taq (QlAGEN, Hilden, Germany) was used in all PCR $\begin{array}{lcc}\text { reactions. The primers } & \text { (forward } & \text { primer: } \\ \text { GGAGTCACACACTCCACCT-3; } & \text { reverse } & \text { primer: }\end{array} 5^{\circ}-$ 
CTGATTGGAAACCTTATTAAG-3) were designed to amplify a 525 bp fragment containing the -174 restriction site according to the sequence of the IL 6 promoter (Collado-Escobar et al., 2000). The cycling conditions were as follows: $95^{\circ} \mathrm{C}$ for $15 \mathrm{~min}$, followed by 35 cycles consisting of $95^{\circ} \mathrm{C}$ for $60 \mathrm{~s}, 60^{\circ} \mathrm{C}$ for $30 \mathrm{~s}$ and $72^{\circ} \mathrm{C}$ for $10 \mathrm{~s}$; the last cycle was followed by a $10 \mathrm{~min}$ incubation at $72^{\circ} \mathrm{C}$. A $15 \mathrm{Dl}$ aliquot of the PCR product was digested with the restriction enzyme NLa III (New England Biolabs, Beverly, Massachusetts, USA). In addition to the -174 site, two invariant restriction sites were also present in the amplified PCR product. The $C$ allele resulted in fragments of $327 \mathrm{bp}, 122 \mathrm{bp}, 47 \mathrm{bp}$ and $29 \mathrm{bp}$; the $\mathrm{G}$ allele yielded three bands of $327 \mathrm{bp}, 169 \mathrm{bp}$ and $29 \mathrm{bp}$.

\section{Results and discussion}

The frequencies of genotypes of IL-6 in our study population are shown in Table 1. Among the 259 coal miners studied, 258 carried the GG wild type. Only one control subject carried the GC genotype, and the $\mathrm{CC}$ genotype was not detected at all in this study population. Because of this distribution, the original case control analysis was not pursued.

Previously described evolutionary trees suggested that European and southwest Asian (Indian) populations diverged from the Chinese population, with an estimated genetic distance of at least 20000 years (Nei et al., 1986). Studies of IL-6 genotypes with different ethnic populations appear to support this hypothesis (Fishman et all., 1998; Collado-Escobar et al., 2000; Zheng et al., 2000). As shown in Table 1, the genotype distributions of IL-6 in several Caucasian groups were similar, although the allele frequency in European Caucasians increased with higher latitudes, with the highest found in a Finnish population. However, the variant $C$ allele was exceedingly rare in our population of Chinese miners and in two other populations: Japanese women (Nakajima et al., 1999) and an Afro- Caribbean population that immigrated to England. Individuals from the province of Gujarat (in western India) had an allele frequency that was intermediate to those of the Caucasian and Afro-Caribbean/east Asian populations. The polymorphism we detected is associated with the regulation of $\mathrm{IL}-6$ gene transcription (Fishman et al., 1998). Although highly speculative, the high frequency of GG genotype may reflect (unknown) selective pressures in east Asian populations to retain high IL-6 expression, while opposing selective pressures may be at play in Scandinavians.

Although we are drawing a conclusion about genotype distribution based on a selected population of male miners from a case-control study, our results are probably applicable to the general Chinese population. A number of other polymorphisms, including GSTM1, GSTT1, MnSOD, 
OGGI and TNF- $\alpha$ were assessed in the present population (Zhai et al., in preparation; and data not shown); the genotype distributions of these specific polymorphisms were very similar to those found in other studies of Chinese populations from Shanghai, Taiwan, Jiangsu province and Singapore (Seow et al., 1998; Sugimura et al., 2000; London et al, 2000). The genotype distributions of our control subjects, considered separately from the CWP patients, were also similar to published distributions. For each single-nucleotide polymorphism assessed, the genotype distributions were in Hardy-Weinberg equilibrium. In addition to our results, a small Japanese study found an absence of the $\mathrm{C}$ allele in 48 control subjects and 48 hypertensive women; this further corroborates our findings in this related ethnic group. Although extrapolating the present findings to other related ethnicities may be considered (for example, individuals of Korean descent), firm conclusions should be avoided.

\section{Table 1. Genotype frequencies of IL-6 in different ethnic control populations}

\begin{tabular}{|c|c|c|c|c|c|}
\hline Popullation & $\mathrm{n}$ & $\mathrm{GG}(\%)$ & $\mathrm{GC} \%$ & $\mathrm{CC}(\%)$ & $\begin{array}{l}\text { Calculated } \\
\text { Allele } \\
\text { frequency }\end{array}$ \\
\hline $\begin{array}{l}\text { Southern Chinese-Guangxi Province } \\
\text { (this study) * }\end{array}$ & 259 & 99.6 & 0.4 & 0 & $<0.01$ \\
\hline Japanese women (Nakajima et al., 1999) & 96 & 100 & 0 & 0 & $<0.01$ \\
\hline Afro-Caribbeans (Fishman et al., 1998) & 101 & 91.1 & 8.9 & 0 & 0.04 \\
\hline Gujarati Indians (Fishman et al., 1998) & 115 & 73.9 & 24.3 & $\llbracket .7$ & 0.14 \\
\hline $\begin{array}{l}\text { Spanish Caucasian (Collado-Escobar } \\
\text { et al., 2000) }\end{array}$ & 157 & 46.5 & 42.0 & 11.5 & 0.33 \\
\hline British Caucasian (Fishman et al., 1998) & 383 & 37.6 & 44.1 & 18.3 & 0.40 \\
\hline German Caucasian (Bagli et al., 2000) & 351 & 28.2 & 59.3 & 12,5 & 0.42 \\
\hline Swedish Caucasian (Zheng et al., 2000) & 128 & 25.8 & 53.9 & 20.3 & 0.47 \\
\hline $\begin{array}{l}\text { Fininish Caucasian (Hulkkonen et all, } \\
2000 \text { ) }\end{array}$ & 400 & 20.3 & 50.3 & 29.5 & 0.55 \\
\hline
\end{tabular}

In summary, we found that the IL-6 polymorphism at -174 is extremely rare in a population of Chinese coal miners. The $\| L-6$ polymorphism at -174 is unlikely to be contributing significantly to disease susceptibility in Han populations of Southern China. 


\section{Chapter 4}

\section{Genetic Polymorphisms of MnSOD, GSTM1,}

\section{GSTT1 and OGG1 in Coal Workers'}

\section{Pneumoconiosis}

Rihong Zhai ${ }^{1}$, Geoffrey Liu, Xianmin $\mathrm{Ge}^{2}$, Chaomin Yang ${ }^{2}$, Chuonhong Huang ${ }^{3}$. Chuanren $W^{4} \mathrm{u}^{4}$, David Christian! ${ }^{1}$

1. Occupational Health Program, Department of Environmental Health, Harvard School of Public Heath, Boston, Massachusetts, 02115, USA.;2. Division of Pneumovoniosis, Guangxi Institute of Occupational Health, Naming, P. R. China. 3. Division of Occupational Hedth, Guangxi Antiepidemic and Health Center, Nanning, P. R. China. 4. General Hospital of Heshan Coal Mine Co. Heshan, Guangxi, P. R. China.

Published in: Journal of Occupational and Envirommental Medicine 2002; 44:372377 


\begin{abstract}
Little is known about the genetic susceptibility to coal workers' pneumoconiosis (CWP). We investigated the association between genetic polymorphisms of MnSOD, GSTMI, GSTTI, or OGGI and susceptibility to CWP. The study population was composed of 259 Chinese retired coal miners who had similar dust exposure histories. Of these, there were 99 cases with International Labour Organization (LO) chest radio logic criteria for CWP, and 160 controls (with no radio logic criteria for CWP). Individual dust exposure variables were estimated from work histories, and smoking information was obtained from interviews. Polymerase chain reaction (PCR) based techniques evaluated the genotypes of all study subjects. There were no differences in genotype frequency of MnSOD, GSTMI, GSTTI, and OGGl between miners with CWP and miners without CWP, by logistic regression analysis. Cumulative dust exposures, but not genetic polymorphisms, were associated significantly with the presence of CWP. This study illustrates the complexity of factors that may contribute to the development of CWP.
\end{abstract}




\section{Introduction}

Occupational exposure to coal mine dust may lead to the development of coal workers' pneumoconiosis (CWP), characterized by progressive fibrotic reaction in the lungs. Although the precise mechanisms by which coal mine dust leads to pulmonary fibrosis are incompletely understood, considerable evidence has suggested that reactive oxygen species (ROS) and their products are involved in the pathogenesis of CWP (Vallyathan et al., 2000; Schins and Borm, 1999; Mossman and Churg, 1998). Such ROS may be produced by alveolar macrophages (Kamp et al., 1992), polymorphonuclear leucocytes (Driscoll et al., 1991), and epithelial cells (Churg A. 1996) in response to dust stimulation. ROS are also generated from the surface iron on coal mine dust by means of the Fenton-reaction (Dalal et al., 1995). When there is excessive production of ROS, or when there are insufficient in vivo defense mechanisms, oxidative stress may occur. This results in damage to DNA, as well as lipid peroxidation, protein modification, membrane disruption, and mitochondrial damage (Boiteux and Radicellla, 1999).

In response to coal dust-induced ROS, enzymes that function effectively as antioxidants are induced locally in the lung and systematically in the blood. (Janssen et al., 1994; Schins et al., 1997; Schins et al., 1995; Pilger et al., 2000). Some of the mechanisms that provide protection against oxidative damage in human cells involve enzymes such as manganese superoxide dismutase (MnSOD), glutathione S-transferase-mu (GST $\mu$ ), glutathione S-transferase-theta (GST $\theta$ ) (Schins and Borm, 1999; Mossman and Churg, 1998), and OGG 1 (Chevillard et al., 1998). MnSOD exists primarily in the cell's mitochondrial matrix. It converts oxygen radicals into $\mathrm{H}_{2} \mathrm{O}_{2}$ and oxygen. GST $\mu$ and GST $\theta$ are cytosolic enzymes that take part in the conversion of many reactive electrophilic compounds to less reactive and more easily excreted glutathione conjugates (GSH). OGGI is a gene that encodes a DNA gllycosylase that repair damage by catalyzing the removal of 8 hydroxyguanosine (8-OHdG), a major DNA oxidation product.

MnSOD, GSTMI, GSTTI, and OGGI have been found to be polymorphic genes (Ambrosone et al., 1999; Kelsey et al., 1997; Hardie et al., 2000). These polymorphisms may alter the function of the associated enzymes and thereby influence the amount of oxidative damage in the development or severity of a number of disease status. For example, $M n S O D$ genotypes appeared to modify dietary antioxidants in breast cancer susceptibility (Ambrosone et al., 1999), polymorphisms of GSTMI and GSTTI associated with asbestosis development (Kelsey et al., 1997), and $O G G l$ gene polymorphisms have been found to influence the prognosis of lung cancer (Hardie et al., 2000). To explore the possibility that polymorphisms of $M n S O D, G S T M I, G S T T 1$, and $O G G I$ participate 
in the pathogenesis of CWP, we examined the allelic frequencies of these genes in a group of ex-coal miners with documented coal mine dust exposure histories.

\section{Materials and methods}

\section{Study population}

For this case-control study, eligible participants consisted of retired coal miners from the Heshan Coal Mine Company (Guangxi Province, China). All subjects had spent their entire working career with this company. Therefore, their dust exposure histories were known and comparable quantitatively and qualitatively. The miners from this company, all male, had been followed by company physicians from the time of employment throughout their retirement, and had periodic screening chest radiographs. Cases were identified from physician lists. For each case, 1-2 controls (retired coal miners known not to have CWP), matched for age of first exposure, were chosen. This study was approved by the Human Subjects Committee of Heshan General Hospital.

\section{Data collection}

Cases and controls were recruited by their physicians and written informed consent was obtained from each participant. All subjects received a routine medical examination that additionally included a Chinese translation of the standardized American Thoracic Society respiratory questionnaire on respiratory symptoms, occupational histories, and smoking habits (Ferris B., 1978). A chest radiograph, and a blood sample were also obtained. Smoking was quantified in pack-years. Occupational dust exposure was defined by two variables: the duration of exposure measured by the number of years working underground and cumulative dust exposure (in $\mathrm{mg} \cdot$ years $/ \mathrm{m}^{3}$ ). Cumulative dust exposure was calculated by the formula: $\Sigma E_{i} t_{i}$, where $E_{l}$ is the intensity $\left(\mathrm{mg} / \mathrm{m}^{3}\right)$ and $t_{i}$ the duration (years) of the $i$ th interval of exposure (Greaves 1 , 2000 ). $E_{i}$ was defined by the air dust concentrations measured annually (prior to 1957) and monthly (since 1957) for the underground mining area that the individual was assigned to work. Chest radiographs were interpreted according to ILO criteria (1980) (ILO, 1980). All radiographs were scored by a reading panel of three experienced radiologists. Subjects were subdivided into two groups, based on radiograph scores. Subjects with ILO classification of $0 / 0$ were classified as controls in this study. Miners with ILO classification $0 / 1$ or higher were considered CWP cases, since the radiographic category of $0 / 1$ has been shown to highly correlate with pathologic fibrotic lesions in pneumoconiosis (Vallyathan, et al., 1996; Hnizdo et al., 1993). 


\section{Genotyping procedures}

Genomic DNA was extracted from clotted blood using the Puregene DNA isolation kit (Gentra Systems, Minneapolis, MN, USA). The DNA samples were then stored at $-80^{\circ} \mathrm{C}$ until used.

A polymerase chain reaction (PCR) based technique was used for all genetic polymorphisms; negative controls without DNA template were included with each reaction. The hotstar taq (QIAGEN, Germany) was used in all PCR reactions. Details for each polymorphism analysis are summarized in Table 1.

Table 1. Primers for PCR, restriction enzymes and length of expected bands

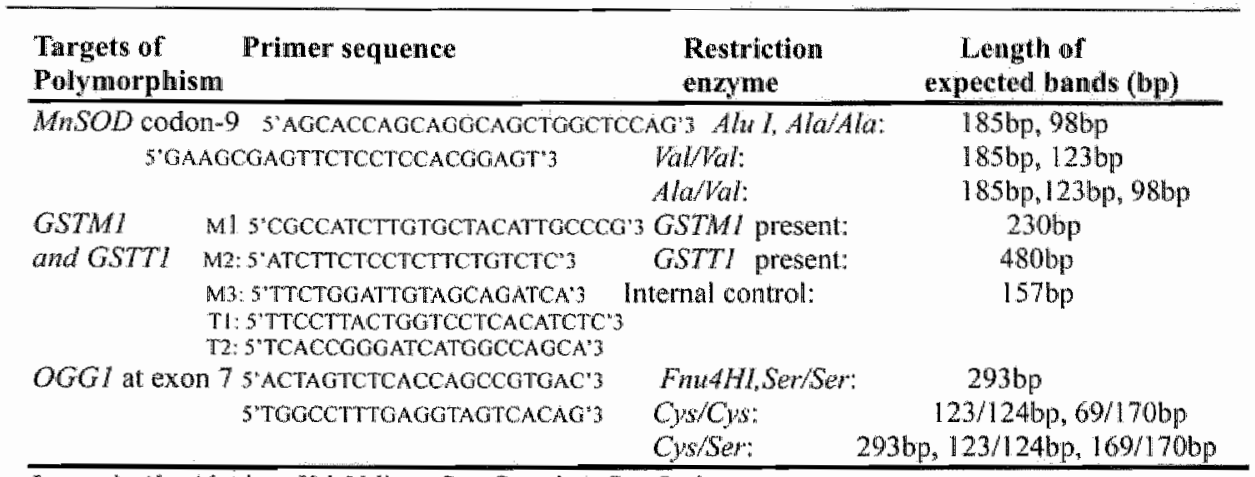

Legend: Ala. Alanine; Val. Valine; Cys. Cysteine; Ser. Serine.

The $A a^{9} / V^{9} l^{9}$ polymorphism in $M n S O D$ was analyzed using PCR amplification, followed by restriction enzyme digestion with $A l u$ I (Biolabs Inc., Beverly, MA, USA). The $A l a^{9} / A a l^{9}$ genotype generated restriction fragments of 185 base pairs (bp) and $98 \mathrm{bp}$; Val/Val genotype produced products of $185 \mathrm{bp}$ and $123 \mathrm{bp}$; and the Ala/Vla genotype gave bands of $185 \mathrm{bp}, 123 \mathrm{bp}$, and $98 \mathrm{bp} \mathrm{(22).} \mathrm{GSTMI} \mathrm{and} \mathrm{GSTTI}$ polymorphisms were genotyped using a modified multiplex PCR procedure (Kelsey et al., 1997; Zhong et al., 1993). In brief, this PCR method had both GST- specific primers in the same reaction mixture together with primers for amplification of a $157 \mathrm{bp}$ internal control band. Primers used were labeled M1, M2, M3, T1, T2 (see Table 1). M1 and M3 amplified a 230 bp product that was specific for the GSTMI gene. TI and T2 amplified a product of 480 bp that was specific for the GSTTI gene. M3 annealed specifically to sequences of the GSTMI gene and yielded a 157 bp internal control product. The absence of a GSTMIspecific 230 -bp product or GSTT1-specific 480 bp product indicated the corresponding null genotype when the internal control $157 \mathrm{bp}$ product was present in the reaction. For the $\mathrm{Ser} / \mathrm{Cys}$ substitution polymorphism in codon 326 of $O G G 1$, the PCR product was digested by the restriction 
enzyme Fnu4HI (Biolabs Inc., Beverly, MA, USA). In the presence of a Cys allele, $123 / 124$ and $169 / 170$ bp fragments were generated from the 293 bp PCR product (Hardie et al., 2000).

\section{Statistical analysis}

Demographic data among cases and controls were cross-tabulated and compared using t-tests. Genotype distribution, allele frequencies and their association with CWP were analyzed using chi-squared tests with Yates's correction, where appropriate. In order to control for potential confounding effects of variables such as smoking, age, and dust exposure levels, multiple logistic regression analysis was performed in which radiographic end points were used as dependent variables and genotypes, age, age at first dust exposure, smoking history, cumulative dust exposure, duration of dust exposure, and time since retirement were entered as independent variables. A two-sided $P$ value less than 0.05 was considered statistically significant.

\section{Results}

A demographic summary of the study population is presented in Table 2 . A total of 265 retired miners volunteered to participate in the health screening. Among them 101 (38\%) subjects were classified as CWP cases. A total of 6 samples (2\%) were not technically suitable for PCR amplification. Hence, genotyping was performed on 259 samples, of which $99(38.0 \%)$ were diagnosed with CWP. The ages and years since retirement in cases were significantly higher than in controls. No differences were found between cases and controls in their mean cumulative cigarette doses, cumulative dust exposure levels, durations of dust exposure, or ages when first exposed to dust.

Frequencies of the polymorphisms of MnSOD, GSTM1, GSTT1, and $O G G I$ in cases and controls are shown in Table 3. No statistically significant differences were observed. The frequency of GSTT1 null in cases was somewhat higher in controls, but this difference was of marginal statistical significance $(p=0.06)$.

In multiple logistic regression models, when polymorphisms of the $M n S O D, G S T M I, G S T T 1$, and $O G G 1$ were separately analyzed, higher cumulative dust exposure and shorter duration of dust exposure were found to be associated with CWP. In the model that included all evaluated polymorphisms, higher cumulative dust exposure $(p<0.01)$, cumulative smoking exposure $(\mathrm{p}=0.05)$, and shorter duration of dust exposure $(p<0.01)$ were all associated with $C W P$ development. In none of the models for the overall population were any genotypes significantly associated with CWP development. 
Table 2 Characteristics of coal miners

\begin{tabular}{|c|c|c|c|}
\hline Variables & $\begin{array}{l}\text { Miners with CWP } \\
(\mathrm{N}=99)\end{array}$ & $\begin{array}{l}\text { Miners without CWP } \\
\qquad(\mathrm{N}=160)\end{array}$ & P-ralue \\
\hline Age (years) & $70.2 \pm 6.7^{37}$ & $67.5 \pm 6.8$ & peo.01 \\
\hline Dust exposure (years) & $20.1 \pm 9.2$ & $21.4 \pm 9.1$ & $\mathrm{NS}$ \\
\hline Cum dust exposure (mg years & $\left.\mathrm{s} / \mathrm{m}^{3}\right) 4222 \pm 2139$ & $40: 19+1999$ & $\mathrm{NS}$ \\
\hline Age at first exposure (years) & $24.7 \pm 5.1$ & $24.3 \pm 4.4$ & NS \\
\hline Years since retirement (years) & $15.9 \pm 6.2$ & $12.8+6.3$ & $\mathrm{P}<0.01$ \\
\hline Smoking (pack years) & $249 \pm 205$ & $246 \pm 245$ & NS \\
\hline
\end{tabular}

\#Values are mean and standard deviation; * by two-sided t-test; NS (not significant): $P>0.05$.

Because smoking was reported to synergistically enhance lung fibrosis (Lapp et al., 1994), we also performed a subgroup analysis restricted to 161 miners (94 cases and 67 controls) with a positive smoking histories. In this model, higher cumulative dust exposure $(\mathrm{p}=0.014)$, shorter duration of dust exposure $(\mathrm{p}<0.01)$ and GSTMI wildtype genotype $(\mathrm{p}<0.01)$ were all significantly associated with CWP. However, we did not have a sufficient number of subjects to assess formally a gene-smoking interaction.

\section{Discussion}

Although the importance of ROS in coal dust-induced lung disorders has been extensively studied, the degree to which anti-oxidants pathways contribute to CWP pathology is unknown. Both in vitro and in vivo studies have suggested that mineral dusts induce the expression as well as release of anti-oxidizing enzymes including catalase and MnSOD (Borm et al., 1986; Janssen et al., 1994). Elevated red blood cell antioxidants (GSH, catalase, SOD) were found in coal miners and pneumoconiosis patients (Engelen et al., 1990; Evelo et al., 1993). Recently, increased levels of SOD, glutathione peroxidase and catalase in bronchoalveolar lavage of coal workers were found correlate with CWP development and progression (Vallyathan et al., 2000). Other investigators reported that reduced extracellular GSH content may be associated with increased fibroblast proliferation (Cantin et all., 1990). Oxidative mechanisms are also likely to be implicated in the malignant effects of mineral dusts (Janssen et al., 1994). Coal dust, asbestos, and silica can stimulate the production of $8-\mathrm{OHdG}$, which can lead to DNA point mutations and oncogene activation (Boiteux and Radicella, 1999). The formation of 8OHdG is excised by glycosylase/AP-lyase, an enzyme encoded by $O G G l$ (Boiteux and Radicella, 1999). These enzymes, which function as either the scavengers of free radicals, in phase II detoxification, or in DNA repair, have a theoretical basis to alter the pathogenesis of CWP. 
Table 3 Distribution of MnSOD, GSTMI, GSTTI, OGGI genotypes in miners with and without CWP

\begin{tabular}{lcc}
\hline Genotypes & Cases & Controls \\
\hline $\begin{array}{l}\text { MnSOD } \\
\text { Alal/Ala }\end{array}$ & $5(5.2 \%)$ & $\mathbf{N}=160 \%$ \\
Ala/Kal & $21(21.6 \%)$ & $5(3.2 \%)$ \\
Vallkal & $71(73.2 \%)$ & $26(16.7 \%)$ \\
GSTMI & & $125(80.1 \%)$ \\
Mi-present & $43(43.9 \%)$ & \\
Null & $55(56.1 \%)$ & $64(40.0 \%)$ \\
GSTTI & & $96(60.0 \%)$ \\
TI-present & $63(64.3 \%)$ & $118(73.8 \%)$ \\
Null & $35(35.7 \%)$ & $42(26.3 \%)$ \\
OGG! & & \\
C/C & $28(28.6 \%)$ & $49(30.6 \%)$ \\
C/S & $54(55.1 \%)$ & $80(50.3 \%)$ \\
S/S & $16(16.3 \%)$ & $30(18.9 \%)$
\end{tabular}

Legend: $P>0.05$ for all chi-squared test. for some polymorphisms, the numbers do not add up to this total because a few individuals had unsuccessful genotyping.

To our knowledge, this is the first study to investigate the role of genetic polymorphisms in MnSOD, GSTMI, GSTTl, and OGGI in the development of CWP. We found no overall differences in the frequencies of polymorphisms between CWP cases and controls, even after adjustment for relevant covariates. However, in an exploratory subanalysis, the GSTMI wild type allele was found to correlate with CWP development. This finding is interesting and needs further explanation in larger studies.

The present study has several strengths. All recruited subjects had complete documentation of dust exposure, smoking habits and an objective outcome variable. The mean duration of dust exposure in the entire group was more than 20 years; thus, the participants were fairly representative of the surviving exposed population. Further, these subjects had spent their entire working career at the same coal mine; hence the 
compositions of the dust that the cases and controls were exposed to were similar. We examined almost all individuats after more than 10 years after their exposure ended, and for more than 30 years after the start of first exposure. Hence, sufficient time had elapsed for the development of dust-induced CWP in our study group. Our results were limited by possible incidence-prevalence bias, but there is no data to suggest that CWP is differentially associated with rapid early mortality (Parker and Banks, 1998). Although miners were identified through a volunteer screening program, there is no biological rationale to suggest that nonparticipants differed from participants by genotype. Furthermore, our overall participation rate was very high $(95 \%)$. Finally, the genotype distribution of all evaluated polymorphisms were similar to other reports in Asian populations (Hiroi et al., London et al., Sugimura et al., 1999), suggesting that no single genotype was underrepresented due to early death or lack of participation in this study.

Logistic regression analysis revealed that higher cumulative dust exposure and heavier cumulative cigarette smoking were independently associated with CWP development. These results are consistent with a number of previous investigations (Mossman and Churg, 1998). In contradistinction, a shorter duration of exposure appeared to be associated with CWP development. This association was likely the result of older miners being exposed to dry mining processes prior to 1957. According to air dust concentration data collected before 1957, the highest dust concentrations at worksites reached as high as $200 \mathrm{mg} / \mathrm{m}^{3}$; after 1957 , this coal mine introduced wet mining processes, which dramatically decreased the air dust levels to less than $10 \mathrm{mg} / \mathrm{m}^{3}$. Miners working prior to 1957 were diagnosed as CWP patients more rapidly and retired at relatively earlier ages; therefore, their duration of dust exposure appeared shorter than those miners without CWP. Our data (Table 2) confirm these association as the ages and time since retirement of CWP cases were higher while their duration of dust exposure were shorter than in miners without CWP. However, when the effects of potential confounding variables such as age, smoking, and duration of exposure were included in the model, only cumulative dust exposure remained significantly associated with CWP development.

Contrary to our hypothesis, our exploratory analysis suggested that smokers with the GSTMI present genotype appeared to have an increased risk of development in CWP. These results should be interpreted with caution, given the relatively small sample size and the lack of biologic plausibility. The glutathione S-transferases are known to be capable of mitigating the cytotoxic effects of free radicals, including those associated with mineral fiber exposure (Hussey et al., 1993). Thus, genetic deficiency in GSTMI should lead to an increase in oxidative 
tissue damage by dust-induced radicals that are substrates for this isozyme. Yet the relative importance of the GSTMI genotype in ROSrelated lung disorders has not been clarified. The results from asbestosis studies were conflicting: some studies correlated GSTM null with an increased risk (Kelsey et al., 1997), whereas other found no association (Jacobson et al., 1994). Further studies with larger numbers of subjects may better define roles of GSTMI genotypes in CWP susceptibility.

Given the current sample size and genotype frequencies and at a two-sided significance level of 0.05 , we had $80 \%$ power to detect odds ratios between 2.0 and 2.4 for the polymorphisms we examined (comparing individuals with at least one variant allele to the homozygous wildtype genotype). Thus, modest associations (i.e. odds ratios between 1.5-2.0) could have been missed in this study. Nonetheless, we were able to exclude a strong association between these polymorphisms and CWP.

In summary, we found no association between MnSOD, GSTMI, GSTT1, OGGI genetic polymorphisms and CWP. This study illustrates the complexity of evaluated genetic factors that may contribute to disease outcome in CWP. The polymorphisms studied may have a limited role in the modulation of ROS-induced damage in CWP development. Other genetic factors involved in collagen turnover, such as abnormal immune surveillance/response, protease/ antiprotease interactions, growth factors synthesis/inhibition, and impaired control of collagen synthesis/degradation, should be investigated in the future studies (Marshall et al., 1997). 


\section{Chapter 5}

\section{Serum levels of tumor necrosis factor $-\alpha(\mathrm{TNF}-\alpha)$,}

\section{interleukin 6 (IL-6), and their soluble receptors}

\section{in coal workers' pneumoconiosis}

Rihong Zhai', Geoffrey Liu', Xianmin Ge', Weihua Bao ${ }^{1}$, Chuanren Wư ${ }^{3}$, Chaomin. Yang', Dexin Liang'

1. Guangxi Institute of Occupational Health, Nanuing, China; 2 . Oecupational Health Program, Department of Environmental Heath, Harvard School of Public Health, Boston, MA, USA; 3. General Hospital of Heshan Coal Mine Co., Heshan, Guangxi, China

Published in: Respiratory Medicine 2002; 96:829-834. 


\section{Abstract}

The aim of this study was to investigate whether systemic tumor necrosis factor alpha (TNF- $\alpha$ ), soluble TNF- $\alpha$ receptors (p55, p75), interleukin 6 (L-6), and soluble $\mathrm{L}-6$ receptor could be markers of biological activities of coal workers' pneumoconiosis (CWP).

The study population was composed of 182 Chinese retired coal miners who had similar dust exposure histories. Among them, 71 were cases with CWP and 111 were controls. Chest radiographs were classified according to International Labour Organization Criteria (ILO, 1980). Individual dust exposure variables were estimated from work histories, and smoking information was obtained from interviews. Serum concentrations of TNF- $\alpha$, TNF- $\alpha$ receptors (p55, p75), IL-6, and IL-6 receptor were measured by ELISA techniques.

Mean serum levels of p55, p75 and IL-6 were significantly higher in cases than in controls ( $\mathrm{p} \leq 0.01$ for each comparison by crude analyses). Results from logistic regression models, adjusted for age, dust exposure variables, and smoking habits, found similar associations between soluble p55 and p75 levels and the presence of CWP. Linear regression analysis revealed that CWP radiographic stage (by ILO criteria) was significantly correlated with the individual serum concentrations of $\mathrm{p} 55, \mathrm{p} 75$ and IL-6. Serum concentrations of all measured cytokines were not correlated to age, dust exposure, or smoking, but there were correlations between soluble p 75 and p55 levels, and between p 75 and IL-6 levels.

The results of this study suggest that serum levels of TNF receptors and IL-6 are associated with the fibrotic process of CWP and serum cytokine levels may be correlated with the severity of CWP. 


\section{Introduction}

Coal workers' pneumoconiosis (CWP), characterized by the development of a progressive fibrotic reaction in the lung, is still a major occupational lung disease in China as well as in the other parts of the world. Although the precise mechanism by which coal mine dust induces lung fibrosis remains incompletely understood, accumulating data suggest that dustinduced overproduction of specific cytokines, such as tumor necrosis factor-alpha (TNF- $\alpha$ ) and interleukin 6 (IL-6)) are involved in the pathogenesis of lung fibrosis (Schins and Borm, 1.999; Vanhee et al., 1995; Piguet, et al., 1990).

In animal studies, silica/bleomycin induces TNF- $\alpha$ production and eventually, lung fibrosis (Piguet, et al., 1990). This fibrosis is less intense with the concurrent administration of anti-TNF antibody (Piguet, et al., 1990). Alveolar macrophages and blood monocytes from patients with CWP release higher amounts of TNF- $\alpha$ and IL-6 (Schins and Borm, 1995; Vanhee et al., 1995; Gosset et al., 1991). The increased expression of TNF- $\alpha$ and IL- 6 mRNA in alveolar macrophages is also found in other models of occupational lung diseases, including chronic beryllium disease (Bost et al., 1993) and asbestosis (Zhang et al., 1993). There is greater secretion of TNF- $\alpha$ and IL-6 in the lungs of patients with progressive massive fibrosis (PMF) than in simple pneumoconiosis (Vanhee et al., 1995). In addition, enhanced production of TNF- $\alpha$ and IL6 is found in areas of pulmonary tissue where coal dust and silica particles are present (Piguet et al., 1990; Vanhee et al., 1995).

Like most polypeptide cytokines, TNF- $\alpha$, and IL- 6 mediate their various cellular responses by binding to specific receptors (Heaney et al., 1996). Mice lacking TNF receptor genes are resistant to the fibrogenic effects of silica and bleomycin, despite increased production of TNF in the lung of the mice (Walker et al., 1991). In addition to the membranebound receptors, two soluble TNF receptors, p55 (sTNF-RI), p75 (sTNFRII), and one soluble IL-6 receptor (sIL-6R) have been identified (Heaney et al., 1996). Systemic infusion of recombinant soluble p55 can reduce collagen deposition in the lung in animal models of silica/bleomycin induced lung fibrosis, presumably by downregulating the activities of TNF- $\alpha$ that mediate pulmonary fibrosis (Walker et al., 1991). Elevated TNF- $\alpha$ receptors in bronchoalveolar lavage have been observed in several inflammatory lung diseases, including pulmonary fibrosis, suggesting that these receptors may be induced in response to inflammation (Walker et al., 1991). One study found that plasma p55 and p75 levels are increased in a small group of patients with CWP compared to controls (Schins and Borm, 1995). Another found elevated serum IL-6 and sIL-6R levels in patients with systemic sclerosis (Hesegawa et al., 
1998).

A]though these data suggest the importance of TNF and IL-6 in the pathogenesis of CWP, little is known about the in vivo relationship between serum levels of TNF- $\alpha$ /TNF- $\alpha$. receptors and IL-6/LL-6 receptor in CWP. In the present study, we compared the circulating levels of TNF- $\alpha /$ receptors and $I L-6 / L-6$ receptor in coal miners with and without CWP. In addition, we examined the relationship between serum levels of cytokines and CWP radiographic stage, a marker of disease severity.

\section{Materials and methods}

Subjects

For this case-control study, participants consisted of 182 retired coal miners (age $67.8 \pm 8.0$ years, all males of Han Chinese descent) from the Heshan Coal Mine Company in Guangxi Province, China. All subjects had spent their entire working career with the same mining company. Therefore, their dust exposure histories were known and comparable quantitatively and qualitatively. The miners from this company had been followed by company physicians from the time of employment throughout their retirement, and had periodic screening chest radiographs. Cases were identified from physician lists, and retired miners known not to have CWP were chosen as controls. Subjects with a known record of current or chronic diseases of lung, liver, and kidney, were excluded. The Human Subjects Committee of Heshan General Hospital approved this study.

\section{Data collection}

Cases and controls were recruited by their physicians and written informed consent was obtained from each participant. All subjects received a routine medical examination that included a Chinese translation of the standardized American Thoracic Society respiratory questionnaire on respiratory symptoms, occupational histories, and smoking habits (Ferris B., 1978). A chest radiograph and a blood sample were obtained. Smoking was quantified in pack-years. Occupational dust exposure was defined by two variables: the duration of exposure (measured by the number of years working underground) and cumulative dust exposure (in $\mathrm{mg} \cdot \mathrm{years} / \mathrm{m}^{3}$ ). Cumulative dust exposure was calculated by the formula, $\Sigma E_{j} \cdot t_{i}$, where $E_{i}$ is the intensity $\left(\mathrm{mg} / \mathrm{m}^{3}\right)$ and $t_{i}$ the duration (years) of the $i$ th interval of exposure. (Greaves I., 2000). $E_{i}$ was defined by the air dust concentrations measured annually (prior to 1957) and monthly (since 1957) for the underground mining area that the individual was assigned to work. Radiographic staging of disease was performed using chest radiographs, which were interpreted according to 
ILO criteria (1980) (ILO, 1980) by a panel of three pulmonary radiologists. Based on the ILO score, miners were categorized into five ordinal stages reflecting disease severity. These radiographic stages were scored as Grade 0 (ILO score of 0/0), Grade 1 (ILO scores 0/1), Grade 2 (ILO scores: $1 / 0,1 / 1$, and $1 / 2$ ) Grade 3 (ILO scores: $2 / 1,2 / 2$ and $2 / 3$ ), and Grade 4 (ILO score of $3 / 1$ or higher). All miners who were Grades 1-4 were classified as cases, because even a score of $0 / 1$ (Grade 1) has been correlated to pathologic fibrotic lesions in pneumoconiosis (Vallyathan et al., 1996).

\section{Detection of cytokines and cytokine receptors}

Serum was separated from blood samples, and stored at $-40^{\circ} \mathrm{C}$ to prevent cytokine degradation. Commercially available ELISA kits (Genzyme Corp., Cambridge, MA, USA) were used to determine the serum concentrations of TNF- $\alpha$, sTNF-Rs, IL-6, and sIL-6R using the procedures provided by the manufacturers. The plates were read at 450 $\mathrm{nm}$ in an automated reader (Bio-Tek EL 311 instrument, Winooski, VT, USA). A standard curve was generated using known concentrations of the recombinant form of the human cytokine/cytokine receptor of interest. Values for samples were determined using the linear portion of the curves for standards run in parallel with each batch of assays.

\section{Statistical analysis}

Continuous data were expressed as means and standard deviations. Mean serum levels of TNF- $\alpha$, TNF- $\alpha$ receptors, IL- 6 and sIL-6R were compared between CWP cases versus controls crudely, using the Student's t-test (for normally distributed data) or the Mann-Whitney U test (for non-parametric data). A multiple logistic regression model was constructed to compare cases versus controls, adjusted for age, cumulative dust exposure, duration of exposure, age of first dust exposure, smoking status, cumulative active smoking, and the serum levels of other cytokines/cytokine receptors.

Multiple stepwise linear regression was used to evaluate the association between serum levels of different cytokines (or their receptors) and CWP radiographic stage. Crude analyses, and analyses adjusted for the same covariates as the logistic regression models were evaluated. Radiographic stages were treated as ordinals. Because the number of individuals with Grade 3 and 4 disease were small, the two grades were merged into one grade (known as $3 / 4$ ) for all statistical analyses. Stepwise linear regression was also used to evaluate associations among the cytokine/cytokine receptor levels. All tests of significance were twotailed. Statistical analysis was performed using the SPSS for Windows 8.0 software (SPSS, Inc, Chicago). 


\section{Results}

\section{Study population}

A demographic sumnary of the study population is presented in Table 1. In this study population, $71 / 182(39 \%)$ were classified as CWP patients and $111(61 \%)$ were classified as controls. Of the cases, $67(93 \%)$ smoked regularly at some point in their lives, while only $57(52 \%)$ of controls were ever-smokers. However, no differences were observed between cases and controls in mean cumulative smoking, measured as packyears. The reason for this discrepancy between pack-years and smoking status is easily explained: individuals diagnosed with CWP were more likely to quit smoking than controls (either from respiratory symptoms or from a greater motivation to quit). There were no differences between cases and controls in terms of duration of dust exposure or cumulative dust exposure, whereas the mean age and the average time of retirement in cases were significantly higher than in cases (Table 1). Within CWP cases, $16,43,9$ and 3 subjects were classified as Grades 1, 2, 3, and 4, respectively.

\section{Table 1. Demographics of the study population}

\begin{tabular}{lccc}
\hline Characteristics & $\begin{array}{c}\text { Cases } \\
\mathbf{N}=71\end{array}$ & $\begin{array}{c}\text { Controls } \\
\mathbf{N}=\mathbf{1 1 1}\end{array}$ & p value \\
\hline Age (years) & $71.1 \pm 7.0$ & $66.2 \pm 6.2$ & $<0.01^{\mathrm{a}}$ \\
Smoking (packyears) & $280.8 \pm 187.2$ & $276.0 \pm 148.7$ & $0.89^{\mathrm{b}}$ \\
Years working underground & $21.8 \pm 9.2$ & $20.1 \pm 10.0$ & $0.23^{\mathrm{a}}$ \\
Age at first exposure & $24.2 \pm 3.8$ & $25.4 \pm 5.5$ & $0.08^{\mathrm{a}}$ \\
Cumulative dust exposure & $4287.5 \pm 2352.4$ & $4098.6 \pm 2043.0$ & $0.57^{\mathrm{a}}$ \\
Time retired (years) & $15.8 \pm 5.5$ & $11.6 \pm 6.1$ & $<0.01^{\mathrm{a}}$ \\
\hline
\end{tabular}

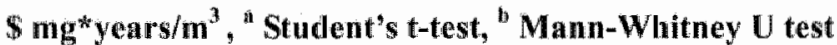

Serum concentrations of cytokines and cytokine receptors

Table 2 presents the mean serum concentrations of the cytokines/cytokine receptors by case status. Serum values of $p 55$ and $\mathrm{p} 75$, detected in all individuals, were each significantly higher in cases versus controls in crude analyses and both significantly and independently higher in adjusted logistic regression models ( $\mathrm{p} \leq 0.01$ for all comparisons). Serum IL-6 was detected in 66/71 (93\%) cases and in 93/111 (84\%) controls $(p=0.05)$. The mean serum IL-6 level was significantly higher than controls in crude analyses $(\mathrm{p}<0.01)$, but not in adjusted analyses $(\mathrm{p}=0.40)$. There were no statistically significant differences in either serum TNF- $\alpha$ or sIL-6R levels between cases and controls ( $p>0.10$ for all comparisons), or between the proportions of cases versus controls with measurable levels of TNF- $\alpha \quad(p=0.24)$. 
Table 2. Mean Serum Levels of Cytokines

\begin{tabular}{|c|c|c|c|c|}
\hline & $\begin{array}{l}\text { Cases } \\
N=71\end{array}$ & $\begin{array}{l}\text { Controls } \\
N=111\end{array}$ & $\begin{array}{c}\text { p-value } \\
\text { mivariate }\end{array}$ & $\begin{array}{l}\text { p-valire } \\
\text { multivariate }\end{array}$ \\
\hline TNF $-\alpha(\mathrm{pg} / \mathrm{m} l)$ & $1.7 \pm 1.7$ & $1.4 \pm 1.1$ & $0.13^{3}$ & 0.25 \\
\hline $\mathrm{ps5}(\mathrm{pg} / \mathrm{ml})$ & $915 \pm 286$ & $704 \pm 256$ & $<0.01^{a}$ & 0.01 \\
\hline $\mathrm{p} 75(\mathrm{pg} / \mathrm{ml})$ & $1047 \pm 240$ & $860+211$ & $<0.01^{*}$ & 0.01 \\
\hline $\mathrm{IL}-6(\mathrm{pg} / \mathrm{ml})$ & $12.6 \pm 12.3$ & $7.2 \pm 8.3$ & $<0.01^{b}$ & 0.40 \\
\hline $\mathrm{s} L-6 \mathrm{R}(\mathrm{pg} / \mathrm{ml})$ & $1054 \pm 544$ & $1064 \pm 508$ & $0.92^{b}$ & 0.69 \\
\hline
\end{tabular}

\footnotetext{
"Mann-Whitney U test; "Student's t-test; * Percent from a logistic regression modlel with serum level of each cytokine/cytokine receptor, adjusted for age, cumulative dust exposure, duration of exposure, age of first exposure, smoking status, and cumulative active smoking.
}

\section{Association between cytoline levels and radiographic stages}

No associations were found between serum levels of TNF- $\alpha$ or IL-6R and radiographic stage. However, with more severe radiographic disease (i.e. higher Grade), the mean serum levels of p55, p75 or IL-6 were higher in crude analyses (see Figures 1-2). In an adjusted linear regression model, a higher radiographic stage was also significantly associated with a higher

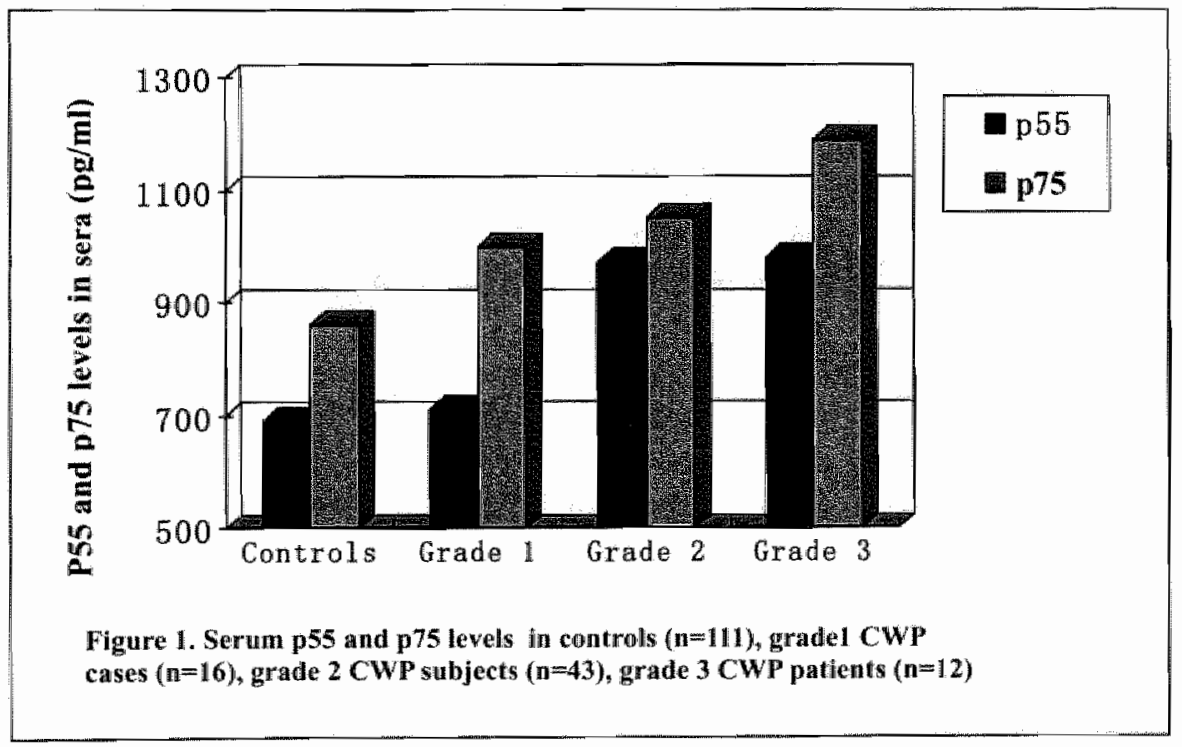




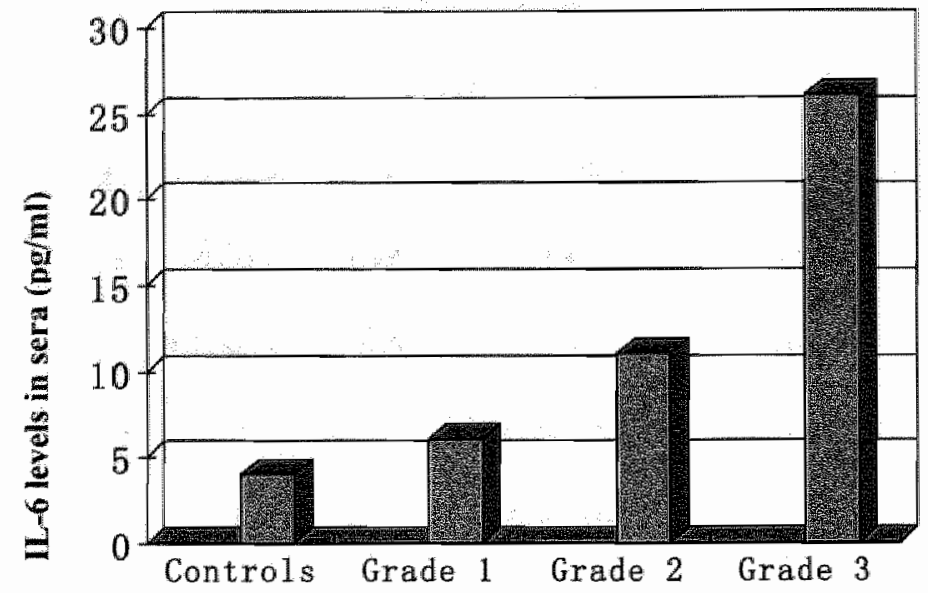

Figure 2. Serum IL-6 levels in controls $(n=111)$, grade1 CWP cases ( $n=16)$, grade 2 CWP subjects $(n=43)$, grade 3 CWP patients $(n=12)$

mean concentration of soluble p55 $(\mathrm{p}<0.01)$, soluble $75(\mathrm{p}<0.01)$, and IL$6(p=0.01)$ in the entire study population. Considering cases only, only serum levels of IL-6 were associated significantly with radiographic stage $(p<0.01)$, although similar non-significant trends were also seen between radiographic stage and either soluble p55 or p75 levels.

Correlations among cytokine levels and other continuous variables

We also evaluated potential correlations between different cytokine/cytokine receptor levels. Serum $\mathrm{p} 75$ levels were correlated to serum $\mathrm{p} 55$ levels (Figure 3; correlation coefficient $\mathrm{R}^{2}=0.09$; $\mathrm{p}<0.01$ by linear regression), while serum $\mathrm{p} 75$ levels were correlated to serum IL-6 levels (Figure $4 ; R^{2}=0.18 ; p<0.01$ by linear regression). Higher cumulative smoking exposure (pack-years as a continuous variable) was associated with a higher CWP stage $(p=0.05)$. No cytokine/cytokine receptor levels were associated with age, smoking, or dust exposure levels. 


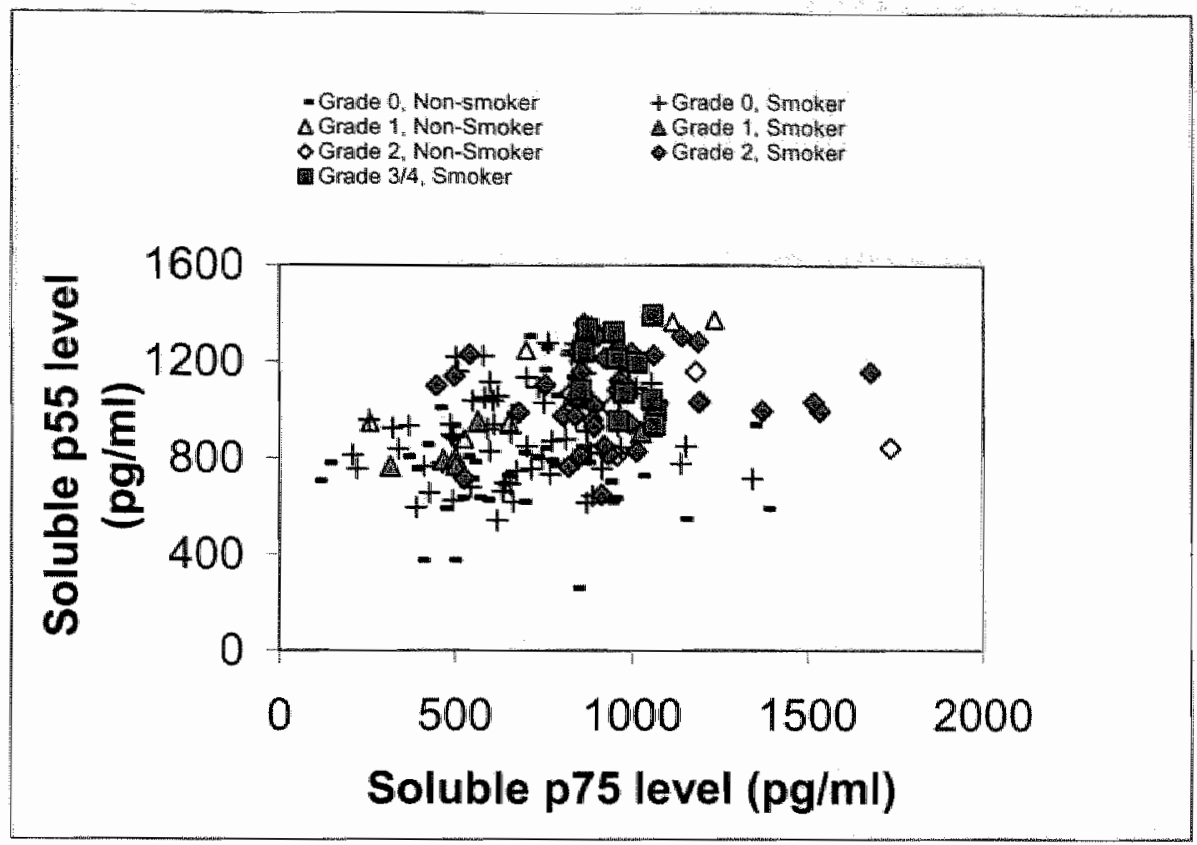

Figure 3: Soluble p55 versus p75 levels

To account for differences in smoking status between cases and controls, we incorporated smoking status (using indicator variables) and pack-years (as a continuous variable) in all adjusted models, and performed separate subanalyses limited to ever-smokers. In every subanalysis, logistic and linear regression results were similar to analyses involving the entire population.

\section{Discussion}

Airway inflammation is a characteristic of CWP, and TNF- $\alpha$ is an inflammatory cytokine (Schins and Borm, 1999). Soluble TNF receptors may represent an attempt by homeostatic mechanisms to ameliorate the systemic effects of TNF- $\alpha$ (Aderka et al., 1992). Soluble TNF receptors are derived by proteolytic cleavage from the extracellular portions of their respective membrane-associated TNF receptors (Heaney and Golde, 1996). These soluble TNF receptors can neutralize circulating TNF- $\alpha$ (Adeka et al., 1992), thus modulating excessive circulating TNF- $\alpha$ and ameliorate inflammatory reactions (Kruppa et al., 1992). In the present study, mean serum levels of the TNF- $\alpha$ soluble receptors, p55 and p75, 


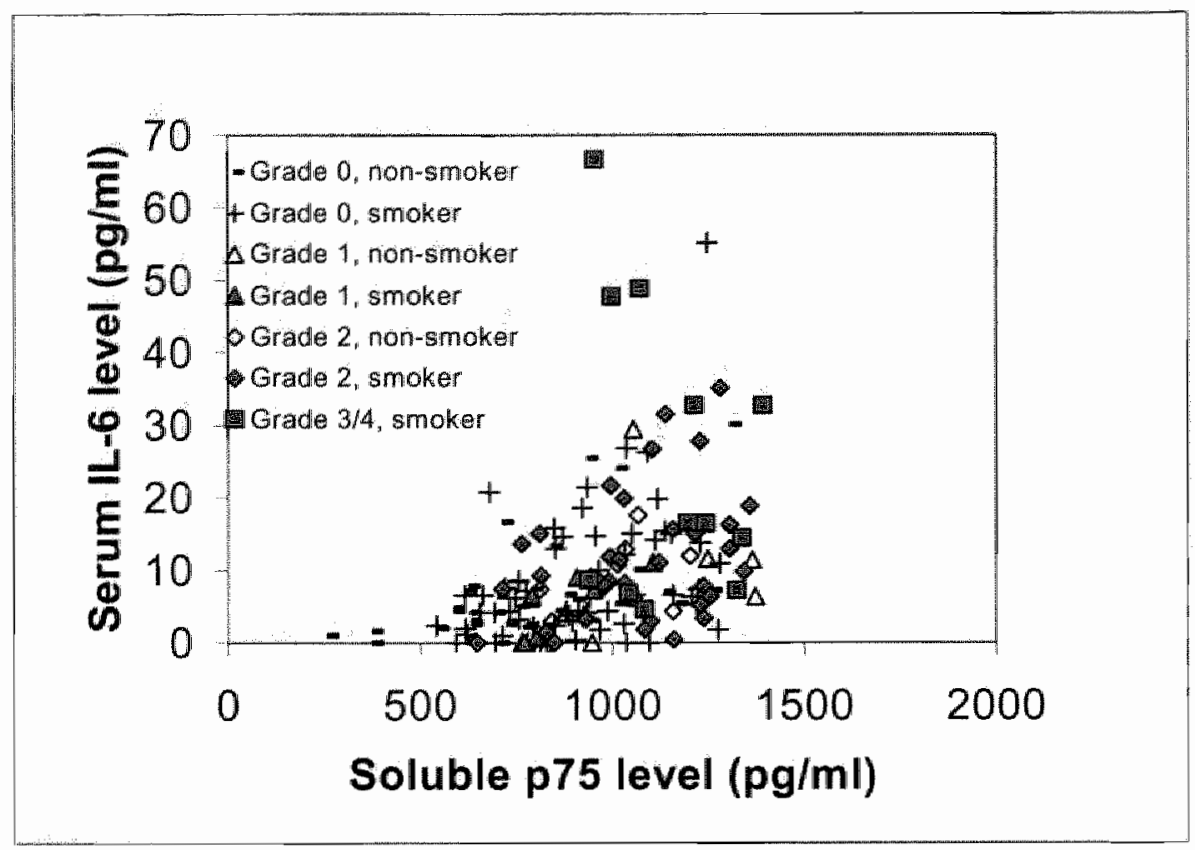

Figure 4: Serum IL-6 versus soluble p75 levels

but not TNF- $\alpha$ itself, were higher in coal miners with CWP compared to controls. High levels of TNF receptors may account for the lack of increased TNF- $\alpha$ in the systemic circulation of cases (Kruppa et al., 1992). This increase in soluble TNF receptors was a relatively early event in CWP patients, as TNF- $\alpha$ levels were already increased in miners with Grade 1 disease. An alternative explanation for why we did not detect a mean serum level difference in TNF- $\alpha$ in cases versus controls is that TNF- $\alpha$ production was suppressed by the higher levels of IL-6 in our cases (Adeka et al., 1989; Tilg et al., 1994).

In the inflammatory milieu of the lung, the interactions of TNF- $\alpha$ and its inhibitors (such as TNF soluble receptors) are complex. Although the p55 and p75 receptors are structurally related, each TNF receptor may be functionally distinct (Peschon et al., 1998). For example, it was reported that most biological responses of TNF- $\alpha$ are mediated through $\mathrm{p} 55$, while p75 functions as both a TNF- $\alpha$ antagonist (by neutrallizing TNF- $\alpha$ ) and as a TNF- $\alpha$ agonist by facilitating the interaction between TNF- $\alpha$ and $p 55$ at the cell surface (Kruppa, et al., 1992). In vitro studies found that p55 
mediates cytotoxicity, whereas p75 stimulates cell proliferation (Tatagla et al., 1991). In double receptor knockout mice, the upregulated expression of $\mathrm{p} 75$, but not $\mathrm{p} 55$, was resistant to the fibrotic effects of silica (Ortiz et al., 1999).

Mean serum IL-6 level, but not mean soluble IL-6 receptor level, was higher in cases than in controls. Higher mRNA production or concentrations of IL-6 were reported in either the pulmonary tissue or BAL fluid of pneumoconiotic patients versus controls (Vanhee et al., 1995; Oliver et al., 1994; Vallyathan et al., 2000). When compared to healthy controls, higher BAL fluid levels of $\mathrm{IL}-6$ were observed in patients with either systemic sclerosis with pulmonary fibrosis (Hesegawa et al., 1998) or idiopathic pulmonary fibrosis (Oliver et al., 1994). Our results, together with these previous findings, suggest that systemic IL-6 may play a role in the pathogenesis of pulmonary fibrosis in CWP.

Although a few studies have evaluated both TNF- $\alpha$ and IL-6 levels in CWP development (Oliver et al., 1994; Vallyathan et al., 2000; Tilg et al., 1994), or p55 and p75 in the plasma of CWP patients (Schins and Borm, 1995), none have examined the association between serum levels of these cytokines/cytokine receptors and CWP radiographic stages. We report that mean $\mathrm{p} 55, \mathrm{p} 75$, and IL-6 serum levels progressively increased with increasing severity of CWP. Multiple linear regression models confirmed that these were independent linear trends in both crude and adjusted models.

Cumulative smoking was associated with CWP severity with borderline statistical significance $(\mathrm{p}=0.05)$. Data from histological studies and animal experiments suggest that, occasionally, smoking can cause diffuse pulmonary fibrosis with low profusion ratings (Frasca et al., 1983). However, whether cigarette smoking can cause radiographic opacities indistinguishable from those due to pneumoconiosis remains controversial. In some studies, the presence of chest radiographic opacities were found to correlate significantly with cigarette smoking (Cockcroft et al., 1983), while others disputed this association $(\mathrm{Ng}$ and Chan, 1991). It is also possible that cigarette smoke may increase lung inflammation, enhancing the fibrogenic effects of inflammatory mediators (such as TNF- $\alpha$ ) that are produced from coal dust exposure.

Unlike other soluble cytokine receptors, sIL-6R has no antagonistic role, but enhances the response to IL-6 (Taga et al., 1989). We found no difference between miners with CWP and without CWP in serum sIL-6R levels. Although IL-6 downregulates sIL-6R gene expression both in vivo and in vitro (Portier et al., 1992), we found no such correlation in our sample of CWP patients.

In conclusion, our study found that higher levels of soluble TNF receptors and higher IL-6 serum levels were each associated 
independently with the presence of CWP, and with the radiographic severity of CWP. Although we performed multiple comparisons between different serologic inflammatory markers, the consistency of the results across stratified and adjusted analyses, consistency across previous reports in this field (albeit most had significantly smaller sample sizes), independence of association in multivariate models, and biologic plausibility lend legitimacy to our results. These findings are consistent with the role of cytokines in the inflammatory pathway, where factors are known to stimulate the production of each other (Vanhee et al., 1995). Although our results do not identify the biological basis for these findings, these results underscore the potential complex interactions between soluble TNF receptors and IL-6 in the pathogenesis of coal dust induced CWP. 


\section{Chapter 6}

\section{Differences in cellular and inflammatory cytokine}

profiles in the bronchoalveolar lavage fluid in

bagassosis and silicosis

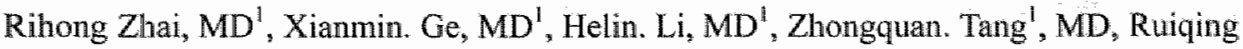
Liao, B. Sci ${ }^{11}$, Jos Kleinjans, $\mathrm{PhD}^{2}$

1. Guangxi Institute of Occupational Health \& Guangxi Worker"s Hospital, Naming, China; 2. Department of Health Risk Analysis and Toxicology, Maastricht University, Maastricht, The Netherlands

Published in: American Journal of Industrial Medicine, 2004, 46:338-344 


\begin{abstract}
Little is known about the crucial mediators involved in the inflammation and fibrogenesis in bagassosis. The aim of this study was to characterize the cellular and cytokine patterns in the airways of bagassosis and to compare these with silicosis subjects and controls. BAL was performed in 11 patients with bagassosis, 16 cases with silicosis, and 8 controls. Differential cell counts, total protein concentration, TNF- $\alpha, \mathrm{IL}-1 \beta, \mathrm{IL}-5$, IL-6, and IL-8 were analyzed in the bronchoalveolar lavage fluid (BALF). The results showed that bagassosis was characterized with hypercellularity with neutrophilia in BALF; while the predominant cell in sillicosis were macrophages. Compared with control subjects, bagassosis and silicosis showed higher TNF, $\alpha, I L-1 \beta, I L-8$, and IL-6 levels in the BALF. Furthermore, IL-6 levels in the BALs of silicosis subjects were significantly higher than that seen in bagassosis. In contrast, bagassosis had higher IL-8 in BALF than that in silicosis. Relationship among these parameters were found between IL-8 levels and neutrophils, lymphocytes and IL- $\mathbb{B}$ in bagassosis, macrophages and IL-1B in silicosis. No significant differences of total protein concentrations and IL-5 in BALF were found between controls or bagassosis, and silicosis. In conclusion, TNF- $\alpha$, IL- $1 \beta$, IL-8, and IL-6 may have important roles in the pathogenesis bagassosis and silicosis. The mechanisms underline the different cellular and cytokine patterns in bagassosis and silicosis warrants further investigation.
\end{abstract}




\section{Introduction}

Hypersensitivity pneumonitis (HP) represents a group of lung diseases characterized by a diffuse inflammatory granulomatous response to a wide variety of inhaled organic dusts (Salman, 1998). The development of such an inflammation may eventually result in diffuse pulmonary fibrosis (Salvaggio, 1997). Farmer's lung and pigeon breeder's lung are probably the most well-known types of HP worldwide. Bagassosis is a form of HP caused by occupational inhalation of bagasse, the fibrous residue of sugarcane after juice extraction, during bagasse processing in the manufacture of papers, building materials, fertilizers, feed, and refractory bricks, etc. (ILO, 1983). Repeated exposure to bagasse may lead to a progression of inflammation and finally to end-stage lung disease with severe fibrosis. Bagassosis has been reported extensively all over the world but little is known about the crucial mediators that involve in the processes of inflammatory and fibrogenesis.

Silicosis can be defined as interstitial pulmonary fibrosis caused by the inhalation of silica particles (inorganic dusts) (ATS, 1997). Silicosis is characterized by a persistent inflammatory response and generation of pro-inflammatory and fibrotic mediators (Mossman, et al., 1998). Neutrophils, macrophages, and T-cells, but also eosinophils have been found in the airways of patients with pneumoconiosis (Mossman et al., 1998). Increased release of inflammatory cytokines, such as IL-1, IL-6, IL-8, and TNF- $\alpha$ have been reported in the lungs and serum of pneumoconiosis patients (Vanhee et al. 1995; Schins and Borm, 1999; Zhai et al., 2002). But it is still uncertain which mechanisms are crucial to the processes of inflammation and fibrogenesis in silicosis .

In spite of their inflammatory component and fibrosing propensity, no direct comparison between bagassosis and silicosis in terms of cell and cytokine patterns in bronchoalveolar lavage fluid (BALF) has been carried out so far. The aim of this study was to investigate cellular and cytokine features in the lungs of patients with bagassosis and to compare them with sillicosis and healthy controls. It was hoped that some insights might be gained which would contribute to better understanding the pathogenesis of bagassosis and silicosis.

\section{Methods}

\section{Study population}

Eleven patients with bagassosis, sixteen patients with silicosis, and eight control subjects were included in this study. All participants were male, nonsmokers. Patients with bagassosis were from a paper mill where they 
handled bagasse fiber for the manufacture of cardboard. Diagnosis of bagassosis was based on general accepted criteria: a documented history of exposure to bagasse preceding disease, respiratory complains, contact avoidance resulted in clinical improvement of respiratory symptoms, chest radiograph alterations. Patients with silicosis were former underground miners, silicosis was diagnosed according to International Labor Organization criteria by a panel of three pulmonary radiologists (ILO, 1980). This study was proved by the Human Institutional Review Board at Guangxi Institute of Occupational Health and was conducted after receiving informed consent in writing from the participants.

\section{Bronchoalveolar lavage and cell processing}

Bronchoalveolar lavage (BAL) was performed through the nose with a flexible fibreoptic bronchoscope. Lidocaine was used as anesthesia and atropine was used to reduce secretions. The bronchoscope was wedged into a subsegment of the right middle lobe and $200 \mathrm{ml}$ of sterile saline at $+37^{\circ} \mathrm{C}$ was instilled in $50 \mathrm{ml}$ aliquots. After the instillation the fluid was gently aspirated and collected in a plastic bottle kept on ice.

The BAL fluid (BALF) was filtered through three layers of sterile gauze. The cellular constituents of the lavage were collected by centrifugation ( $350 \mathrm{~g}$ for $10 \mathrm{~min}$ ), resuspended in Hanks' balance salt solution. The total number of cells was measured with a hemocytometer, and differential cell counts of 200 cells were performed after MayGrunwald-Giemsa staining.

\section{Cytokines and total protein measurement}

Commercially available ELISA kits (Genzyme Corp, Cambridge, MA, USA) were used to determine cytokine concentrations in the BALF samples, using the procedures provided by the manufacturers. Total protein concentration in BALF was measured using the radioimnunoassay (RIA) method, Kits were purchased from China Institute of Atomic Energy, Beijing.

\section{Statistical analysis}

Data are expressed as mean $\pm \mathrm{SD}$. Comparisons were performed using Student's $t$ test for parametric data, the Mann-Whitney U-test for nonparametric data. The correlation of different parameters was analyzed with Spearman's rank correlation coefficient $\left(r_{s}\right)$. Two tailed tests were performed and a $p$ value of less than 0.05 was considered significant. 


\section{Results}

Subjects characteristics

Table 1 summarizes the clinical data and BAL parameters of the study population. The mean ages for subjects with HP, silicosis, and controls were $39.73 \pm 8.33,43.81 \pm 8.34$, and $48.00 \pm 9.43$ years respectively. BAL was well tolerated by all subjects. The mean lavage volume recovered was $61 \pm 7 \%$ of that instilled in all subjects.

\section{Alveolar cell profiles}

Total cell counts in BALF were higher in patients with bagassosis than that in workers with silicosis and controls subjects. Neutrophils were

Table 1 BAL Characteristics of Subjects

Bagassosis Silicosis Controls

$\begin{array}{lccc}\text { Number } & 11 & 16 & 8 \\ \text { Age } & 39.7 \pm 8.3 & 43.8 \pm 8.3 & 48.0 \pm 9.4 \\ \text { Sex } & \mathrm{M} & \mathrm{M} & \mathrm{M} \\ \text { Total cells }\left(\times 10^{6} / \mathrm{L}\right) & 269.3 \pm 237.3^{* *} & 81.6 \pm 53.8 & 61.8 \pm 26.6 \\ \text { Macrophages }(\%) & 21.6 \pm 21.9^{* *} & 71.9 \pm 20.8 & 75.0 \pm 27.9 \\ \text { Neutrophils }(\%) & 69.9 \pm 2.4 .5^{* * *} & 26.8 \pm 20.4 & 18.1 \pm 28.1 \\ \text { Lymphocytes }(\%) & 2.8 \pm 3.3^{*} & 1.2 \pm 1.5^{*} & 6.8 \pm 6.3 \\ \text { Eosinophils }(\%) & 1.2 \pm 1.3^{*} & 0.06 \pm 0.2 & 0.13 \pm 0.36 \\ \text { Total protein }(\mathrm{mg} / \mathrm{ml}) & 0.55 \pm 0.53 & 0.32 \pm 0.34 & 0.39 \pm 0.31\end{array}$

HP or silicosis versus controls: * $(\mathrm{p}<0.05), * *(p<0.01)$

HP versus silicosis: \# $(\mathrm{p}<0.05), \#$ ( $<<0.01)$

significantly higher in subjects with bagassosis (mean, 69.9\% compared with $26.8 \%$ in patients with silicosis, $18.1 \%$ in controls). Bagassosis patients and silicosis subjects had significantly lower lymphocyte counts than did controls. Eosinophils were significantly higher in bagassosis $(1.2 \%)$ than that in the silicosis subjects $(0.06 \%)$ and the controls $(0.13 \%)$.

\section{Cytokines in BALF}

TNF- $\alpha$, IL-1 $1 \beta$, IL-8, and IL- 6 levels in the BALF of bagassosis and silicosis were significantly higher $(p<0.01$ for all parameters) versus that in controls (Figure 1-4). IL-6 levels in the BALFs of silicosis subjects were significantly higher than that seen in bagassosis $(p<0.05)$. In contrast, IL-8 concentrations in the BALF of patients with bagassosis were significantly higher than that in silicosis $(p<0.01)$. IL-5 concentrations in the BALF in bagassosis and silicosis were likely higher than that in controls, but these differences were not statistically 
significant $(22.0 \pm 17.1,43.4 \pm 50.4,13.5 \pm 8.3$ respectively). Total protein concentrations in the lavage fluids showed no significant differences between control subjects, or silicosis, and bagassosis.

\section{Correlations between cytokines and cellularity}

To assess the physiologic relevance of our observations; we determined whether the cytokine concentrations in the BALF correlated with number of neutrophils, macrophages as measures of active inflammation. Using Spearman's rank correlation models, we found a significant correlation between IL-8 levels and neutrophil cellularity in the BALF of patients with bagassosis $(r=0.6, p=0.02)$. A significant correlation between the percent of lymphocytes and IL-1 $\beta$. was also found $(r=0.6, p=0.02)$ in bagassosis patients. In patients with silicosis, the percent of macrophages was significantly correlated with IL- $1 \beta$, concentrations $(r=0.6, p=0.03)$. No additional informative correlations were found among the other main alveolar parameters evaluated in this study.

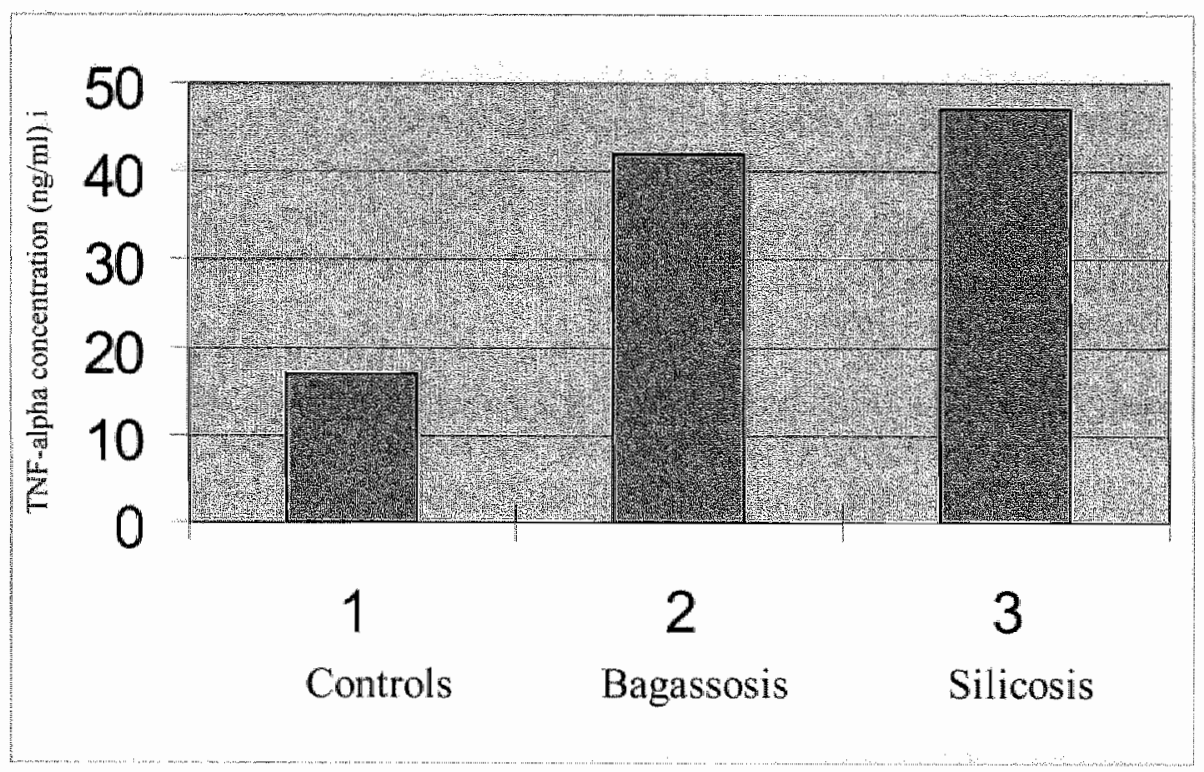

Fingure 1. TNF $\alpha$, levels in the BALF of controls $(n=8)$, bagassosis $(n=11)$, and silicosis $(n=16)$. Values are means $\pm S D$. 
Chapter 6

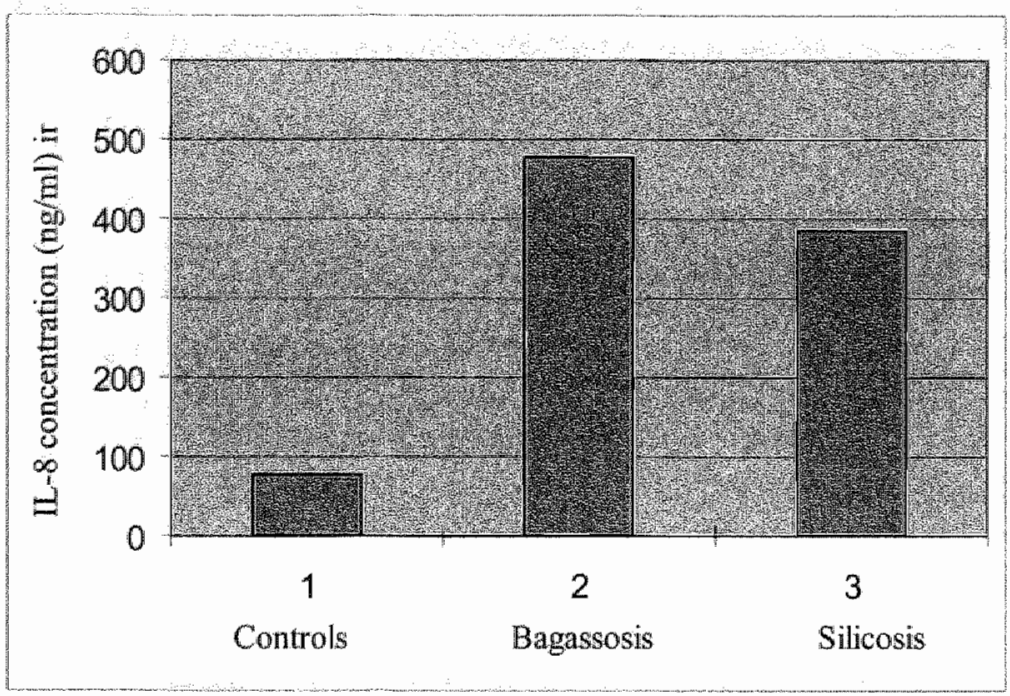

Figure 3. IL-8 levels in the BALF of controls $(n=8)$, bagassosis $(n=11)$, and silicosis $(\mathrm{n}=16)$. Values are means $\pm S D$.

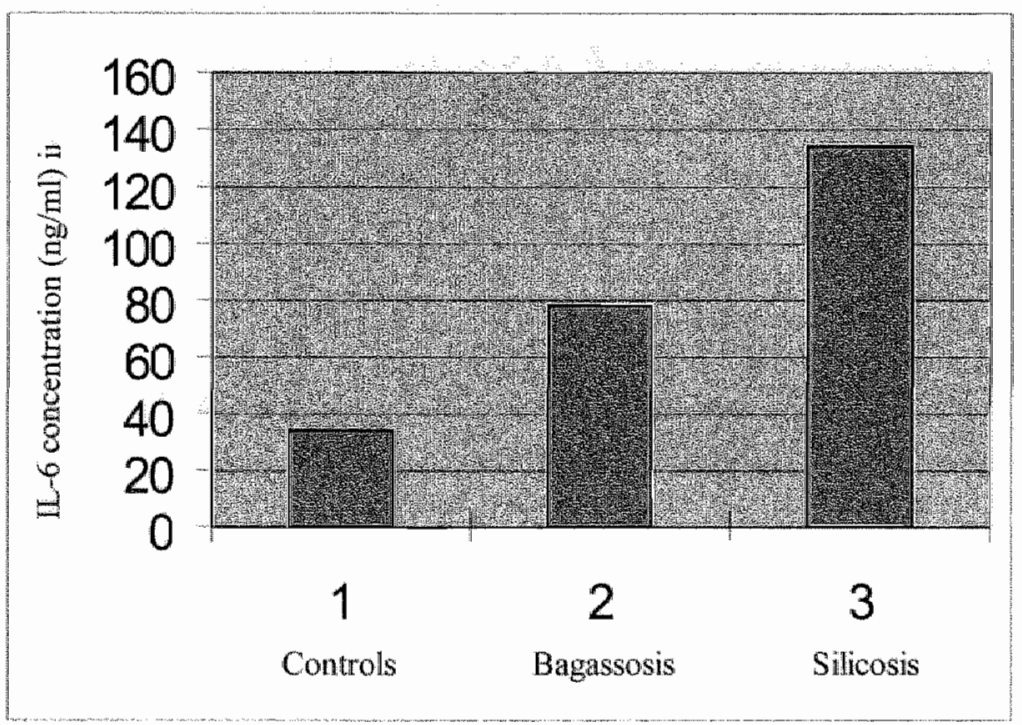

Figure 4. IL-6 levels in the BALF of controls $(n=8)$, bagassosis $(n=11)$, and silicosis $(n=16)$. Values are means $\pm S D$. 
The recruitment of neutrophil is associated with the inflammatory reaction, recruitment of other inflammatory cells, such as macrophages and T lymphocytes, and lung fibrosis (Pardo et al., 2000; Rochester et al., 1993; Vallyathan et al., 2000). In addition to the chemoattractant effect of IL-8, TNF- $\alpha$ may increase the adhesion of neutrophils in the local circulation and their migration into the lung, and IL-] probably enhances their activity in situ. (Vanhee et al., 1995) TNF- $\alpha$ and IL-1 induce IL-8 production in many cell types (Rochester and Elias, 1993), which may therefore partly explain the elevated $I L-8$ in patients with bagassosis and in silicosis.

IL-6 is greatly increased in silicosis and to a less degree in bagassosis. Similar increased levels of IL-6 have been reported in silicosis and coal workers' pneumoconiosis (CWP) (Gosset et al., 1991; Duits et al., 1991). But no correlation was seen between IL- 6 concentrations and any type of cell in the BALF. The lack of relations may be explained by the fact that most resident and migratory lung cells are capable of producing IL-6, although macrophages are probably the main source of IL-6 (Rochester and Elias, 1993). lL-6 is important in inflammatory processes, due to its ability to induce cellular adhesion molecules on monocytes, which facilitates their infiltration into the lung (Vanhee et al., 1995). IL-6 seems to be implicated in an autoimmune processes in association with TNF and IL-1 (Dinarello, 1991). IL-6 could also be implicated in the fibrotic response due to its ability to induce collagen synthesis in vivo (Choi et al., 1985). However, IL-6 has also been reported to extent some antiinflammatory properties. IL-6 has been shown to have a protective role in a mouse model of HP and of septic shock (Denis, 1992; Barton and Jackson, 1993). It also suppressed endotoxin-induced neutrophil exudation, as well as TNF and IL-1 production (Ulich et al., 1991; Schindler et al., 1990; Aderka et al., 1989). Thus increased IL-6 may be related to intense counterbalanced anti-inflammatory and anti-fibrosing activities. Indeed, there was evidence suggested that pretreatment of mice with anti-IL-6 antibodies significantly suppresses the fibrosing outcome in HP (Denis, 1992).

The factors in bagasse that cause the airway inflammation are unknown. Dusts containing endotoxins and the mold cell-wall constituent (1-3)- $\beta$-D-glucan may be of importance and inhalation of lipopolysaccharide (LPS) and glucan has been shown to cause inflammatory process in the airways (Sandstrom et al., 1992; Fogelmark et al., 1994). Our previous measurements at a paper mill suggested that levels of endotoxin ranging from $1-1500 \mathrm{ng} / \mathrm{m}^{3}$ and glucan levels up to $48 \mathrm{ng} / \mathrm{m}^{3}$ in bagasse dusts (data not shown), values that has been found to have health effects among waste collectors in Sweden (Thorn et al., 1998). 
Microorganisms, such as thermoactinomyces sacchari and fungi are also important constituents of bagasse (Seabury et al., 1968). Exposure of epithelial cells to bacterial induced an increased secretion of IL-8 (Eckmann et al., 1993). Bagasse fiber itself can also induce interstitial pneumonitis and granulomatous lesions (Zaidi et al., 1983). Neutrophil recruitment to the airways induced by bacteria is mediated by IL- 8 (Jorens, 1994).

Our data demonstrate up-regulation of TNF- $\alpha, I L-1 \beta$ in the BALF of silicosis, confirming previous studies (Vallyathan et al., 2000). TNF- $\alpha$ and IL-1 concentrations were also increased in bagassosis, suggesting a role for these cytokines in bagassosis, which is in agreement with those reported by others in farmers" lung (Denis et al., 1993). TNF- $\alpha$, IL-1 are known to play a central role in inflammation, cell adhesion, collagen, synthesis, and autoimmune processes (Rochester and Elias, 1993). Overproduction of TNF- $\alpha$, IL- 1 is associated with the severity of dust exposure and disease progression in silicosis (Vanhee et al., 1995). Data in experimental animals have shown an important involvement of both IL- 1 and TNF- $\beta$, in the production of granulomas and fibrotic lesions in the lungs after an inflammatory process (Cromwell et al., 1992). Furthermore, IL-1 and TNF- $\alpha$, have the ability to enhance the generation of IL-6 and IL-8 (Rochester, 1993).

In summary, we have shown for the first time a substantial amounts of inflammatory biomarkers in the lungs of patients with bagassosis. We also found inflammatory profiles in bagassosis and silicosis are different, suggesting that inflammatory mechanisms in bagassosis differs from those in silicosis. Further studies should be directed at the elucidation of these mechanisms with a view to discovering more specific therapy for these diseases. 


\section{Chapter 7}

\section{Toxicological features of different coal dusts:}

\section{possible correlation with prevalence of coal}

\section{workers' pneumoconiosis}

Rihong Zhai ', Jacco.J Briedé2, van Herwijnen M.H.M², Maas, L.M., Moonen, E.J.C., Yanyan Zheng ', Ruiqing Liao ', Junrong Ou ', and Jos Kleinjans ${ }^{2}$

1. Guangxi Institute of Occupational Health \& Guangxt Worker's Hospital, Nanning; China; 2. Department of Health Risk Analysis and Toxicology Mastricht University Mastricht, The Netherlands 


\section{Abstract}

Although epidemiological studies have shown that the prevalence of coal workers" pneumoconiosis (CWP) differs remarkably between different coal mine regions; the underlying mechanisms for the regional differences in CWP prevalence are not well understood. To investigate if differences in the physicochemical properties of the coal dusts may contribute to the difference in CWP prevalence, coall samples from three different coal mines (brown, bituminous and anthracite coal) with a prevalence of CWP of $0.15,6.70$, and $1.58 \%$ respectively in China were studied for elemental content, reactive oxygen species (ROS) generating capacity, and (oxidative) DNA damage, and cytokine production in human lung epithelial cells (BEAS-2B). Results showed that metal compositions differed among three coal samples. Brown coal and anthracite coal contained a relatively high content of iron compared to bituminous mine. The highest contents of $\mathrm{Zn}, \mathrm{As}, \mathrm{Cu}, \mathrm{V}, \mathrm{Ni}$, and $\mathrm{Co}$ were found in brown coal; and the lowest contents of $\mathrm{Zn}, \mathrm{Cu}$, were observed in bituminous coal. Anthracite coal generated highest levels of ROS, while bituminous coal had the lowest ROS generating capacities. Oxidative DNA damage induced by the lowest dose of coal dust, but not DNA strand breaks, correlated with CWP prevalence. All coal samples induced an increased production of IL-6 in BEAS-2B cells in a dose-dependent way, and the brown and bituminous coals were more potent than anthracite coal in inducing IL-6 release. In contrast, TGF- $\beta$ generation from BEAS-2B cells decreased with increased coal dust exposure. Anthracite coal was more potent than both the brown and bituminous coals in stimulating TGF- $\beta$. production. TNF- $\alpha$ generating potency was relatively low for all coal samples at all dust concentration cultures. The results of this study indicate that oxidative DNA damage contributes to the prevalence of CWP. Because ROS and cytokine generating capacity of coal dust was not correlated with oxidative DNA damage, it is suggested that other mechanisms than coal dust induced radical and cytokine release per se contribute to cellular oxidative stress. 


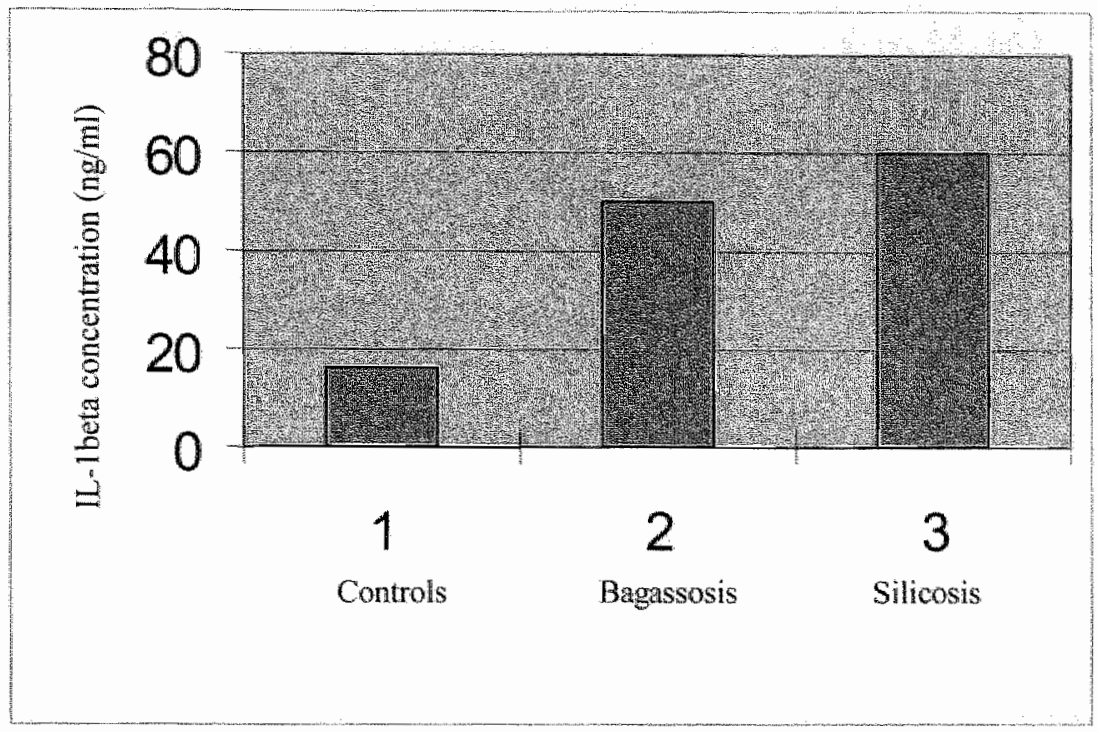

Figure 2. IL-1B levels in the BALF of controls $(n=8)$, bagassosis $(n=11)$, and silicosis $(\mathrm{n}=16)$. Values are means $\mathrm{SD}$.

\section{Discussion}

This is the first study to assess inflammatory profiles in the lungs of patients with bagassosis and compare with silicosis and normal controls. Patients with bagassosis and silicosis showed active inflammatory processes in their lungs and shared several common particularities with silicosis an increased pro-inflammatory cytokines such as TNF- $\alpha, \mathrm{IL}-1 \beta, \mathrm{IL}-6$, and IL- 8 in the alveolar spaces. However, the inflammatory cellular and cytokine patterns in bagassosis were different from that seen in silicosis, differentiating the two disease characteristics. Different cell counts in BALF showed a striking hypercellularity with neutrophilia in patients with bagassosis compared with that in silicosis and normal controls, in agreement with the findings in BALF of farmer's lung (Fournier et al., 1985). Furthermore, there was a significant correlation between neutrophils and the IL-8 concentrations, suggesting that IL-8 may pay an important role in the influx of neutrophils into the airways. Neutrophils are rarely present in the lower respiratory tract of healthy individuals. IL-8 is a potent neutrophil chemoattractant and activator, and its secretion leads to a neutrophilic influx (Strieter et al., 1992). Acute HP is characterized by an early neutrophilic infiltrate (Fournier et al., 1985). 


\section{Introduction}

Coal is the single largest fuel source for the generation of electricity worldwide. Inhalation of coalmine dust may cause pneumoconiosis; chronic obstructive bronchitis, and stomach cancer (Schins and Borm 1999). Among the respiratory diseases, the most commonly occurring type of respiratory disease in coal miners is coal workers' pneumoconiosis (CWP), including simple pneumoconiosis (SP) and progressive massive fibrosis (PMF).

It has been widely shown that the prevalence and severity of CWP differed remarkably between different coalmines, despite comparable exposure to respirable dust. For instance, the first round of the US National Study of CWP (NSCWP), which was completed in 1971, has examined a total of 9076 miners from 29 bituminous and 2 anthracite mines (Morgan et al. 1973). The average exposure concentration in USA mines during that period was $3 \mathrm{mg} / \mathrm{m}^{3}$. It was found that $41 \%$ of Eastern Pennsylvania anthracite miners had SP and a further 1.4\% had PMF, but the comparable figures for bituminous miners in Colorado and Utah were $4 \%$ and $0.4 \%$, respectively (Attfield and Morring 1992). Subsequent studies of the same mines (in 1972-1975, 1977-1981, and 1985-1988) have shown that this regional difference persisted with greater risk of CWP in eastern coal miners than in western coal miners (Attfield and Seixas 1995). In France, coal miners of the Provence never had CWP, while the prevalence of CWP in coal miners of Nord Pas De Calais was 24\% (Amoudru et al. 1987). In Britain, one coal mine with an dust exposure concentration of $9.1 \mathrm{mg} / \mathrm{m}^{3}$ (pre-1970) reported $2.4 \%$ of CWP and another coal mine with only $3.6 \mathrm{mg} / \mathrm{m}^{3}$ reported $16.6 \%$ of CWP (Crawford et al. 1982).

Initially, coal dust was considered innocuous, and due to apparent similarities in chest radiographs CWP was thought to be a variant of silicosis. However, coalmine dust usually contains relatively small amount of free crystalline silica (quartz), and further studies revealed that quartz is only a minor contributor to CWP development in general (Hejny $\mathrm{H}$ et al. 1989; Walton et al. 1977). On the other hand, it has been reported that coal rank was an important factor contributing to the development of CWP (Ortmeyer et al. 1973; Bennett et al. 1979). Coal rank is defined as the extent to which the organic materials have matured during geological time. The three major coal types ranked in order of increasing heat value are: lignite (brown coal) < bituminous < anthracite. A correlation between coal rank and cell cytotoxicity as well as CWP prevalence has been established (Schulz HM. 1997; Miller and Jacobsen 1985). These observations have led to the hypothesis that coal rank is one of the major physicochemical properties of the coal dusts attributable to the regional differences in the prevalence of CWP. 
In past years increasing evidence from in vitro, animal studies, and epidemiological studies has indicated that reactive oxygen species (ROS) and cytokines are involved in the pathogenesis of CWP (Schins and Borm 1999; Mossman and Churg 1998). The goal of the present study was to identify coal dust features that may contribute to the observed regional differences in the prevalence of CWP. In this study, elemental composition and ROS generating capacities, as well as inducibility of oxidative DNA damage and cytokine release in human lung epithelial cells (BEAS-2B) were investigated using coall samples from three coalmines with different CWP prevalence in China.

\section{Materials and methods}

\section{Materials}

Glass capillaries $(100 \mu \mathrm{l})$ for ESR spectroscopy were purchased from Brand AG (Wertheim, Germany). All other chemicalls were from Sigma (St Louis, MO). Solutions of 5,5-dimethyl-1-pyrrolline-N-oxide (DMPO) in nitrogen-flushed Milli-Q water were further purified by charcoal treatment. Stock concentrations of DMPO were determined spectrophotometrically by using the extinction coefficient $\gamma=7700 \mathrm{M}^{-}$ $\mathrm{cm}^{-1}$ at $234 \mathrm{~nm}$.

\section{Coal samples}

The selection of coal samples for the present study was based on previous data from a national epidemiological study on pneumoconiosis in China. This study investigated 53,409 mines and factories in 29 provinces of China. A total of 7.6 million workers for whom dust exposure histories between 1949 and 1986 were available, was examined (MOH. 1992). From three coal mines (a brown, bituminous, and anthracite mine respectively) located in Guangxi Province, south of China, a total of 10,713 miners was investigated, of whom 5930 were in the bituminous mine, 4045 in the anthracite mine, and 738 in the brown mine. CWP prevalence in the brown, bituminous, and anthracite mine were $0.15 \%$, $6.7 \%$, and $1.58 \%$ respectively (Liang et al. 1991 ) (Table 1). Coal samples were freshly collected from these three mines and sealed in polyethylene bags. This was to ensure that the collected coal samples were not exposed to oxygen, which leads to chemical changes in the samples.

To obtain respirable particles, each coal sample was ground by hand using an agate mortar until the diameter of $>70 \%$ of coal particles was smaller than $10 \square \mathrm{m}$. The size distribution of the coal dusts was determined using hemocytometer according to China Standards for Measuring Dust Size Distribution (MOH. 1985). After grinding, the dust sample was transferred into plastic tubes, sealed, and stored for further analysis. 


\section{Elemental composition}

The elemental content of the coal samples was determined using atomic absorption spectrometry (AAS). Before analysis with AAS, coal dust samples were boiled under reflux for 2,5 hours in aqua regia and subsequently filtrated. Iron and zinc were measured by flame AAS (Varian spectra20) with an air/acetylene flame and with deuterium background correction. Analysis from iron and zinc were carried out at $248.3 \mathrm{~nm}$ and $213.9 \mathrm{~nm}$ respectively. Copper $(\mathrm{Cu})$, arsenic (As), lead $(\mathrm{Pb})$, cadimium $(\mathrm{Cd})$,

Table 1. Coal workers' pneumoconiosis (CWP) prevalence in different coal mines in Guangxi, China

\begin{tabular}{lcccc}
\hline Mine & No. of miners mean dust con.\# & $\mathrm{SiO}_{2}(\%)^{*}$ & $\begin{array}{c}\text { CWP prevalence\% } \\
(1950-1986)\end{array}$ \\
\hline Brown & 20574 & 80.77 & 1.6681 & 0.68 \\
Bituminite & 10579 & 11.56 & 3.0819 & 8.63 \\
Anthracite & 7596 & 61.77 & 1.4551 & 1.19 \\
\hline
\end{tabular}

H: Geometric mean, $\mathrm{mg} / \mathrm{m}^{3}$ * The content of $\mathrm{SiO}_{2}$ in coal sample.

cobalt (Co), nickel (Ni) and vanadium (V) were measured with graphite furnace AAS (Varian spectra400) with Zeeman background correction at a wavelength of $327,197.2,283.3,228.8,242.5,232.0$ and $318.5 \mathrm{~nm}$ respectively.

The total transition metal (TTM) content was calculated as the sum of $\mathrm{Co}, \mathrm{Cu}, \mathrm{Fe}, \mathrm{Ni}, \mathrm{V}$ and $\mathrm{Zn}$

\section{Measurement of ROS generating capacity by coal samples}

Dust samples were treated as previously described by Van Maanen et al. (van Maanen et al, 1999). Electron spin resonance (ESR) spectra were obtained using a Bruker EMX 1.273 spectrometer equipped with an ER $4119 \mathrm{HS}$ high sensitivity resonator and $12 \mathrm{~kW}$ power supply operating at $\mathrm{X}$ band frequencies. Instrumental conditions were as described before (van Maanen et al, 1999). Quantization of the spectra (in arbitrary units) was performed by peak surface measurements using the WIN-EPR spectrum manipulation program (Bruker, Bremen, Germany).

\section{Cell culture and treatment}

A human bronchial epithelial cell line (BEAS-2B) from the American Type Culture Collection (ATCC) was used as a model system for human epithelial lung cells. Cells were routinely cultured in serum-free keratinocyte growth medium (Keratinocyte SFM, GiBCO Invitrogen 
corporation, Carlsbad, CA, USA), supplemented with $50 \mu \mathrm{g} / \mathrm{ml}$ bovine pituitary extract (BPE), $5 \mathrm{ng} / \mathrm{ml}$ recombinant epidermal growth factor (rEGF), $5 \mu \mathrm{g} / \mathrm{ml}$ human transferrine, $50 \mu \mathrm{g} / \mathrm{ml}$ gentamicin, $250 \mu \mathrm{g} / \mathrm{ml}$ fungizone, and $50 \mathrm{ng} / \mathrm{ml}$ hydrocortisone.

Before cell incubations were performed, cytotoxicity of the different coal dust samples was tested by the MTT test (Mossman. 1983). For that, cells were plated into 96 wells tissue culture plates at $1 \times 10^{4}$ cells $/ 100 \mu$ ] and cultured at $37{ }^{\circ} \mathrm{C}$ with $5 \% \mathrm{CO}_{2}$. After 2 days, fresh medium was added to each well. At confluence, coal dust samples were added in concentrations of $0,8,32,40100$ and $200 \mu \mathrm{g} / \mathrm{cm}^{-2}$ and incubated for $5 \mathrm{~h}$ at $37{ }^{\circ} \mathrm{C}$ in $5 \% \mathrm{CO}_{2}$. Subsequently, $25 \mu \|$ of MTT (3-(4,5dimethylthiazol-2-yl)-2,5-diphenyltetrazolium bromide dissolved in sterile PBS was added. After an incubation period of $3 \mathrm{~h}\left(37^{\circ} \mathrm{C}, 5 \%\right.$ $\mathrm{CO}_{2}$ ), the medium was replaced by $200 \mu \mathrm{l}$ DMSO. Formazan crystals were dissolved by gently shaking the plate for 1 minute, and absorption was read at $540 \mathrm{~nm}$ using a microplate reader (Biorad, Hercules, CA, USA). Cytotoxicity was expressed as the percentage of viable cells (Dong et al. 1994).

For experiments, cells were seeded in $150 \mathrm{~cm}^{2}$ culture flasks and grown till confluence. Before adding the coal dusts to the cells, LPS was inactivated by heating the coal dusts for 18 hours at $110{ }^{\circ} \mathrm{C}$. To prevent iron-related artifacts, the day before exposure to the dusts the medium was replaced by medium without transferrine. 24 Hours after the medium was changed, the cells were exposed to the different coal dusts at three different concentrations $\left(10,50,100 \mu \mathrm{g} / \mathrm{cm}^{2}\right)$ respectively. Cells incubated with either $200 \mu \mathrm{M} \mathrm{H}_{2} \mathrm{O}_{2}$ or $0.5 \mu \mathrm{g} / \mathrm{ml} \mathrm{LPS}$, were used as positive controls. After 2 hours exposure to coal dusts the cells were harvested for 8-oxodG and comet analysis.

\section{Oxidative DNA damage analysis by HPLC-ECD}

HPLC-ECD detection of 8-oxo-dG formation was based on a method described earlier (De Kok, et al, 1994). Briefly, after extraction, DNA was digested into deoxyribonucleosides by treatment with nuclease P1 [0.02 $\mathrm{U} / \mu \mathrm{l}]$ and alkaline phosphatase $[0.014 \mathrm{U} / \mu \mathrm{l}]$. The digest was then analyzed by HPLC with electrochemical detection, using a Supelcosil ${ }^{\mathrm{TM}}$ LC- 18 S column ( $250 \times 4.6 \mathrm{~mm}$ ) (Supelco Park, Bellefonte, PA) and an electrochemical detector (Antec, Leiden, the Netherlands). The mobile phase consisted of $10 \%$ aqueous methanol containing $94 \mathrm{mM} \mathrm{KH}_{2} \mathrm{PO}_{4}, 13$ $\mathrm{mMK}_{2} \mathrm{HPO}_{4}, 26 \mathrm{mM} \mathrm{NaCl}$ and $0.5 \mathrm{mM}$ EDTA. Elution was performed at a flow rate of $1.0 \mathrm{ml} / \mathrm{min}$ with a lower detection limit of $40 \mathrm{fmol}$ absolute for 8-oxodG, or 1.5 residues $/ 10^{6} 2^{2}$-deoxyguanosine (dG). 8-oxodG was detected at a potential of $850 \mathrm{mV}$ and $\mathrm{dG}$ was simultaneously monitored 
at $260 \mathrm{~nm}$. Oxidative DNA damage is expressed as 8-oxodG $/ 10^{6} \mathrm{dG}$ ratios.

Single cell gel electrophoresis for detection of DNA strand breaks (Comet assay)

DNA strand breaks in BEAS cells were determined by single cell gel electrophoresis (Singh et al, 1988), according to the guidelines recently proposed by an expert panel (Tice, et al, 2000). Microscope slides (Menzel-Glaser, Braunschweig, Germany) were coated with a layer of $1.5 \%$ agarose. The slides were dried and kept at $4^{\circ} \mathrm{C}$ before use. BEAS cells were harvested from the 24-well plates using trypsin and were then suspended in HBSS. Subsequently, $25 \mu \mathrm{l}$ of the cell suspension $\left(2 \times 10^{6}\right.$ cells $/ \mathrm{ml}$ ) was mixed with $75 \mu \mathrm{l} 0.65 \%$ low melting point agarose. This mixture was added to the pre-coated slides and covered with a cover glass. Following solidification for 45 minutes at $4^{\circ} \mathrm{C}$, cover glasses were removed and slides were immersed in lysis buffer $(2.5 \mathrm{M} \mathrm{NaCl}, 100 \mathrm{mM}$ EDTA, $10 \mathrm{mM}$ Tris-base, $1 \%$ sodium lauryl sarcosinate, $\mathrm{pH} 10 ; 10 \%$ DMSO and $1 \%$ Triton X-100 added just before use) and stored overnight at $4^{\circ} \mathrm{C}$. Subsequently, slides were placed in an electrophoresis tank filled with ice-cold buffer ( $300 \mathrm{mM} \mathrm{NaOH}, 1 \mathrm{mM}$ EDTA, pH 13) for 20 minutes. Electrophoresis was conducted at $300 \mathrm{~mA}$ and $25 \mathrm{~V}$ for 20 minutes. After electrophoresis, slides were neutralized by repeated washing ( $3 \times 5 \mathrm{~min})$ with neutralization buffer $(0.4 \mathrm{M}$ Tris, $\mathrm{pH} 7.5)$. Finally, slides were immersed in ethanol and allowed to dry under air. Slides were stored at $4{ }^{\circ} \mathrm{C}$ until analysis. All steps described were performed in the dark/dimmed light to prevent additional DNA damage. Dried slides were stained with ethidium bromide $\left(10 \mu \mathrm{g} / \mathrm{ml}\right.$ in $\left.\mathrm{H}_{2} \mathrm{O}\right)$ and comet appearances were analyzed using a Zeiss Axioskop fluorescence microscope (Zeiss, Stuttgart, Germany). Samples were tested in duplicate ( 2 independent incubations) within each single experiment. On every single slide 50 cells were analyzed randomly using a comet image analysis software program (Comet assay II, Perceptive Instruments, Haverhill, UK). Comets were visualized using $200 \mathrm{x}$ magnification and DNA single strand breakage was expressed as tail moment.

\section{Detection of cytokines in cell culture supernatants}

BEAS-2B cells were exposed to the different types of coal particles at concentrations of $10,50,100 \mu \mathrm{g} / \mathrm{cm}^{2}$ for $18 \mathrm{~h}$ respectively. The cell culture supernatants were collected and then analyzed for cytokine concentrations. Analysis of the IL-6, TGF- $\beta$, and TNF- $\alpha$ in epithelial cell supernatants was quantified using enzyme-linked immunosorbent assay (ELISA) according to the manufacturer's manual (Genzyme Corp., Cambridge, MA, USA). Increase in color intensity was determined using 
an automated plate reader (BIO-Tek, ELX808). Color intensity was converted to nanograms of IL- 6 , TGF- $\beta$, and TNF- $\alpha$, respectively using standard curves derived from recombinant human $I L-6$, TGF- $\beta$, or TNF- $\alpha$ (Zhai et al. 2002).

\section{Statistical methods}

Data presented are means \pm standard deviations. ESR data are expressed as percentage of dust-induced signal and represent the mean of two experiments. DNA strand breakage was expressed as tail moment. Data were expressed as mean ( $1 \mathrm{SD}$ ) from 2 experiments. Oxidative DNA damage is expressed as 8 -oxodG $/ 10^{6} \mathrm{dG}$ ratios. Correlations were calculated using the Pearson correlation coefficient.

\section{Results}

Elemental composition of the coal samples

Table 2. Elemental contents of the different coal samples

Elements (mg/kg)

\begin{tabular}{lcccccccccc} 
Coall samples & $\mathrm{Fe}$ & $\mathrm{Zn}$ & $\mathrm{As}$ & $\mathrm{Cu}$ & $\mathrm{Pb}$ & $\mathrm{Cd}$ & $\mathrm{V}$ & $\mathrm{Ni}$ & $\mathrm{Co}$ & TTM $^{*}$ \\
\hline Brown & 26.42 & 161.79 & 18.98 & 39.98 & 24.40 & 1.01 & 70.85 & 25.98 & 4.60 & 374.01 \\
Bituminous & 14.16 & 63.47 & 7.11 & 19.54 & 168.63 & 0.60 & 38.04 & 5.76 & 2.86 & 310.17 \\
Anthracite & 15.27 & 99.36 & 5.30 & 22.33 & 13.74 & 1.15 & 5.30 & 1.86 & 1.23 & 165.54 \\
\hline
\end{tabular}

*Total transition metal (TTM) content ( $\mathrm{Fe}+\mathrm{Zn}+\mathrm{As}+\mathrm{etc} . . . .$.$) .$

Analysis of elemental composition showed considerable differences between the three coal samples (Table 1). Brown coal and anthracite coal contained a relatively high content of iron compared to bituminous mine. The highest contents of $\mathrm{Zn}, \mathrm{As}, \mathrm{Cu}, \mathrm{V}, \mathrm{Ni}$, and $\mathrm{Co}$ were found in brown coal; and the lowest contents of $\mathrm{Zn}$, $\mathrm{Cu}$, were observed in bituminous coal. With respect to $\mathrm{Pb}$, the content was highest in bituminous coal and the lowest in anthracite coal. Cadmium was present at roughly similar contents in all samples except for the relatively lowest in bituminous coal.

\section{ROS generating capacities}

ESR data suggest that coal dusts can react with $\mathrm{H}_{2} \mathrm{O}_{2}$ to release shortlived, hydroxyl radicals. The generation of such radicals was monitored by ESR after the addition of $\mathrm{H}_{2} \mathrm{O}_{2}$ and a spin trap, DMPO, to an aqueous suspension of coal particles. For all types of coal dusts, the ESR signal showed a $1: 2: 2: 1$ pattern with hyperfine splitting constants of $\mathrm{a}_{\mathrm{N}}=\mathrm{a}_{\mathrm{H}}=14.9$ $\mathrm{G}$ that is typical of the DMPO-OH adduct. There was no obvious correlation between the ROS-generating capacity (Figure 1). and the CWP prevalence as associated with the different coal dusts: The coal 
sample from the anthracite mine with a CWP prevalence of $1.58 \%$ released the highest amounts of ROS. In contrast, coal dust from the brown mine where a CWP prevalence of $0.15 \%$ was observed, generated intermediate levels of ROS. The coal from bituminous mine, with highest prevalence of CWP $(6.70 \%)$, had lowest ROS generating capacities. Furthermore, no correlation was observed between individual or total transition metal content and ROS generating capacity of coal dusts.

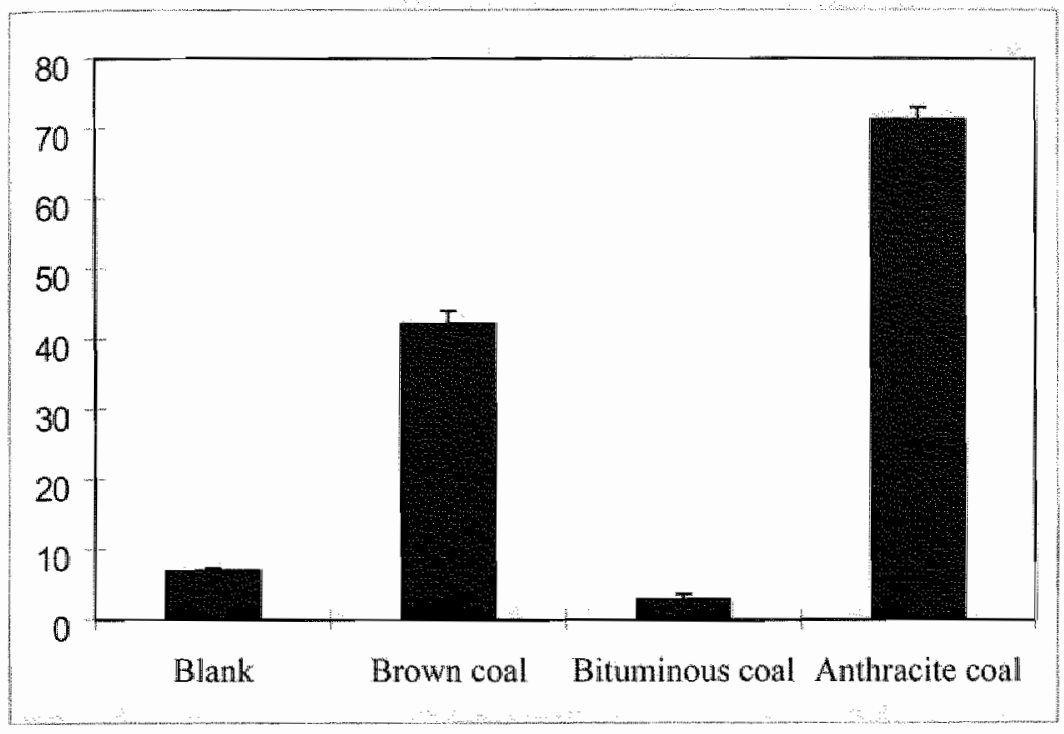

Figure 1. Hydroxyl radical generation by brown, bituminous, and anthracite coal dusts. Dust samples were incubated at $37^{\circ} \mathrm{C}$ for $10 \mathrm{~min}$ in the presence of $\mathrm{H}_{2} \mathrm{O}_{2}$ and DMPO. Each bar indicates the mean DMPO-OH peak surface (in arbitrary units). ESR conditions were according to Maanen et al. (van Maanen et all, 1999).

\section{Oxidative DNA damage in human lung epithelial cells}

Fig. 2 illustrates that bituminous and anthracite coal dusts induced higher 8oxodG/dG ratios than brown coal in BEAS-2B cells. In addition, an obvious dose-dependent effect on 8-oxodG/dG ratios was found for BEAS-2B cells cultured with anthracite coal dusts. Interestingly, there was a positive correlation, between 8-oxo-dG formation induced by the lowest dose of coal dust and CWP prevalence $(R=0,77)$. Because the epidemiological data of CWP prevalence is expressed as a single number for each type of mine, significance of this correlation could not be determined. 


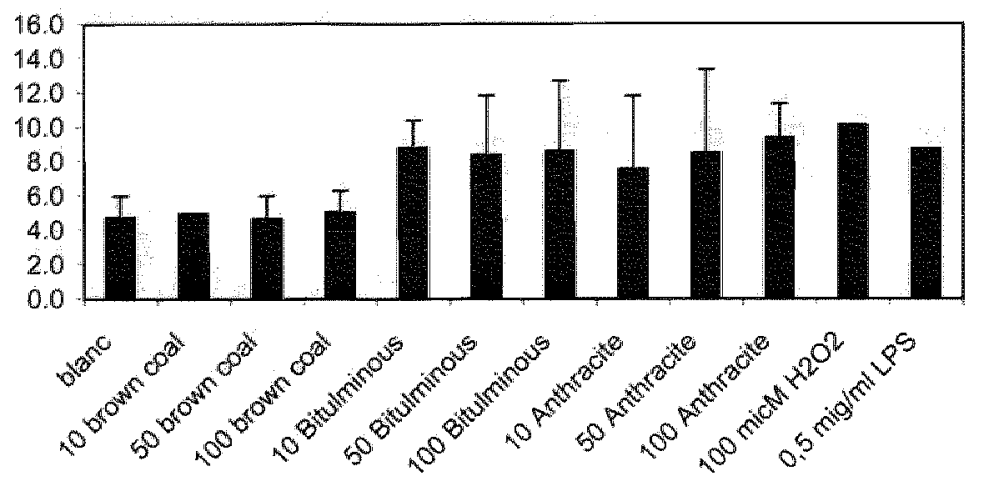

Figure 2. Oxidative DNA damage (8-OHdG) by brown, bituminous, and anthracite coal dust in BEAS cells. Dusts were incubated with BEAS cells at concentrations of 10,50 , and $100 \mathrm{mg} / \mathrm{cm}^{2}$ respectively for 2 hours. The bars represent the mean $80 x o / 10^{5} \mathrm{dG}$ ratios.

\section{DNA single strand breaks}

DNA strand breakage as measured by the comet assay on BEAS-2B cells exposed to three coal samples showed that brown coal and anthracite coal induced longer tail length than that of bituminous coal, suggesting greater DNA damage by brown coal and anthracite coal. Thus coal dust is able to induce the formation of DNA single strand breaks, but in contrast to oxidative DNA damage, this type of DNA damage was not correlated to CWP prevalence.

\section{Effects of coal dust exposure on cytokine release}

TNF- $\alpha$ TGF- $\beta$ and IL- 6 , are cytokines that widely known to be involved in the pathogenesis of CWP (Schins and Borm 1999). All coal samples induced a release of TNF- $\alpha$, TGF- $\beta$ and IL- 6 from BEAS cells in a dose dependent way, but the potency varied widely (Figure $4 \mathrm{~A}, \mathrm{~B}, \mathrm{C}$ ). All particle samples induced a coal dust concentration dependent increased production of IL-6 compared to control. Furthermore, the brown and bituminous coals were more potent in this production. No correlation was found with CWP prevalence, but the dose-dependent increase in IL-6 production was significantly correlated with decreased ROS generating capacity of the different types of coal dusts $(R=0,86, p=0,03)$. 


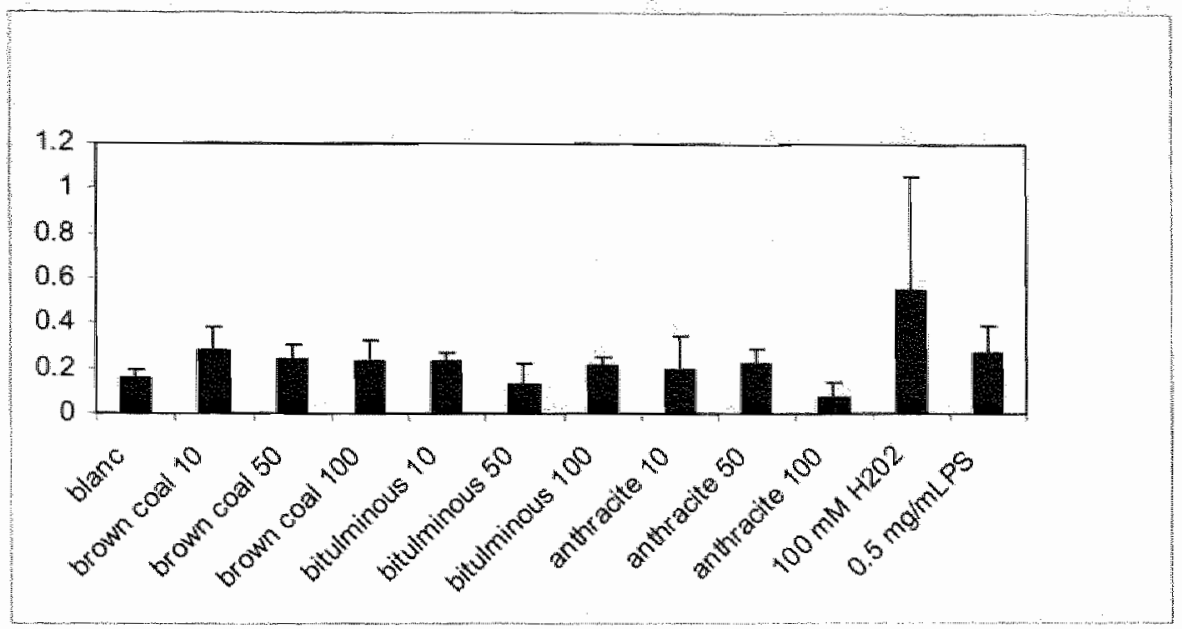

Figure 3. DNA strand breaks evaluated by comet assay in human lung epithelial cells, comparing brown, bituminous, and anthracite coal dusts. Dusts were incubated with BEAS cells at concentrations of 10,50 , and $100 \mathrm{mg} / \mathrm{cm}^{2}$ respectively for 2 hours. Each bar indicates the mean tail moment of the comet experiments in arbitrary units.

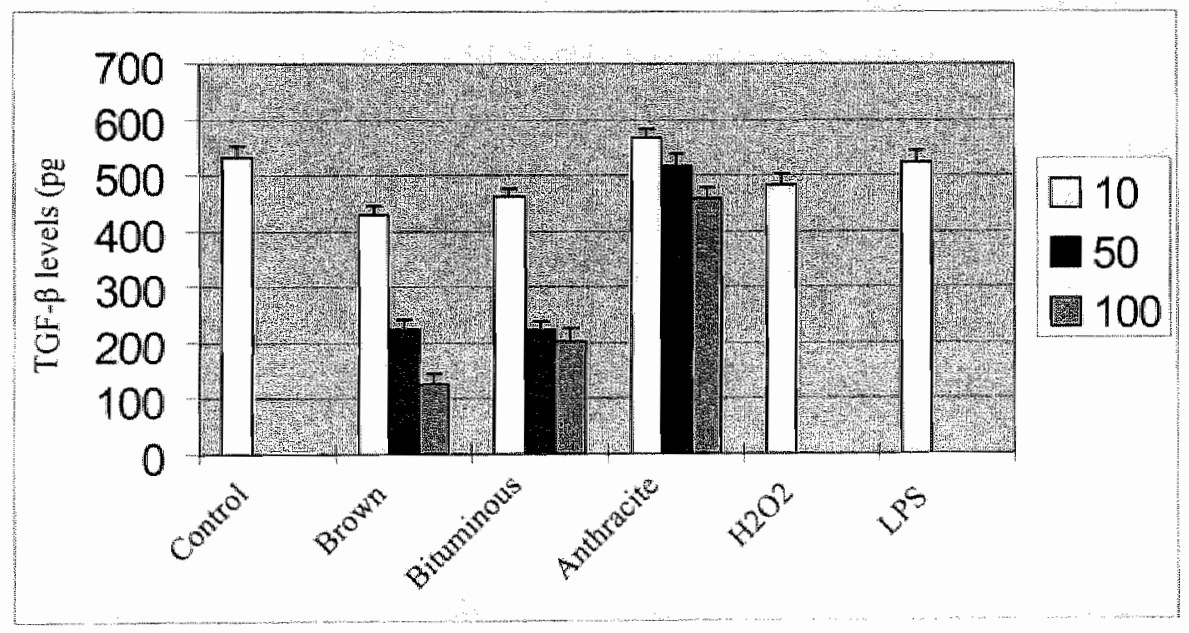

Figure 4A. TGF- $\beta$ release after exposure of BEAS-2B cells to coal particle suspensions at three concentrations $\left(10,50\right.$ and $100 \mathrm{mg} / \mathrm{cm}^{2}$ respectively) for 18 h. $200 \mu \mathrm{M} \mathrm{H}_{2} \mathrm{O}_{2}$ or $0.5 \mu \mathrm{g} / \mathrm{ml}$ LPS were incubated with cells as positive controls. 


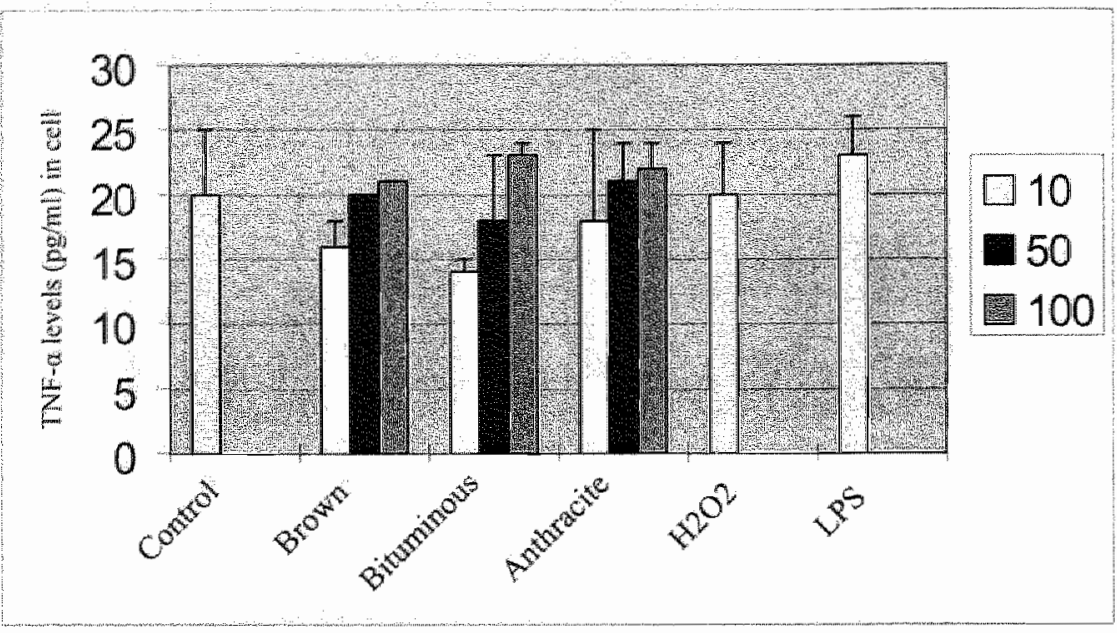

Figure $4 B$. TNF- $\alpha$ release after exposure of BEAS-2B cells to coal particle suspensions at three concentrations $\left(10,50\right.$ and $100 \mathrm{mg} / \mathrm{cm}^{2}$ respectively) for 18 h. $200 \mu \mathrm{M} \mathrm{H}_{2} \mathrm{O}_{2}$ or 0.5 $\mu \mathrm{g} / \mathrm{ml}$ LPS were incubated with cells as positive controls.

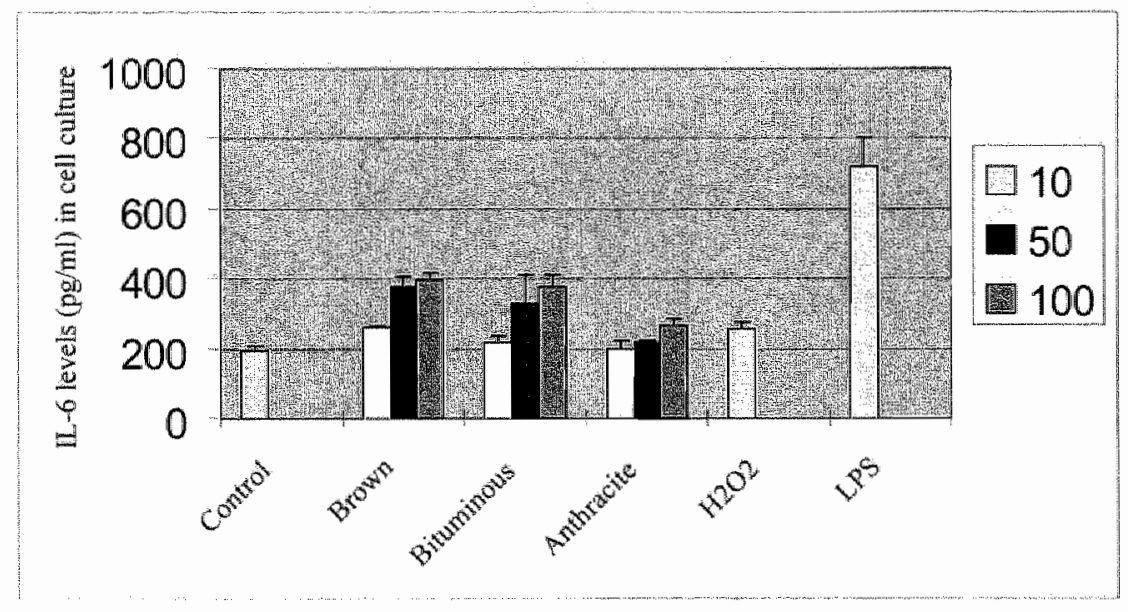

Figure $4 \mathrm{C}$. IL-6 release after exposure of BEAS-2B cells to coal particle suspensions at three concentrations $\left(10,50\right.$ and $100 \mathrm{mg} / \mathrm{cm}^{2}$ respectively) for $18 \mathrm{~h} .200 \mu \mathrm{M} \mathrm{H}_{2} \mathrm{O}_{2}$ or $0.5 \mu \mathrm{g} / \mathrm{ml}$ LPS were incubated with cells as positive controls.

In contrast to $L \mathrm{~L}-6$ generation, the release of TGF- $\beta$. decreased dosedependently with increasing coal particle concentration. Anthracite coal was more potent than both the brown and bituminous coals in stimulating TGF- 
Although TNF- $\alpha$. production was detected in all cell cultures, TNF $-\alpha$ generating potency of the particles was negligible.

\section{Discussion}

Although the prevalence of CWP increases roughly as the coal rank increases, the coal sample which presents the highest coal rank (anthracite) in our studied samples induces only $1.58 \%$ CWP. In contrast, the bituminous coal which is in the middle of the coal rank induces highest prevalence of CWP $(6.70 \%)$. Similar results were allso reported by others in France where an anthracite coal mine had about $12 \%$ of CWP, while the prevalence of CWP in another bituminous mine was $24 \%$ (Amoudru C 1987; Huang et al.1999). Since coal rank is only an indicator of coal maturation, other chemical substances associated with coal rank may play a role in inducing CWP.

In the present study, we found that inducibility of oxidative DNA damage by low dose of coalmine dust in vitro in BEAS cells is correlated to the prevalence of CWP. Several authors have shown that mineral dusts are able to increase oxidative DNA damage in vitro (Leanderson et al. 1988; Chen et al. 1997) and in vivo (Yamano et al. 1995; Nehls et al. 1997), but no association between mineral dust-induced oxidative DNA damage and pneumoconiosis development has been established. CWP is a condition associated with airspace inflammation (Schins and Borm 1999). A large number of studies have demonstrated that oxidative stress plays an important role in the injurious and inflammatory response in airway diseases (Castranova and Vallyathan 2000; MacNee W. 2001). Furthermore, elevated 8-OH-dG has been closely linked to the pathogenesis of inflammatory diseases, such as rheumatoid arthritis, systemic lupus erythematosus, multiple sclerosis, and systic fibrosis (Evans et al. 2004). It has been proposed that elevated oxidative DNA damage may exert their toxic effects for the cells by inducing proinflammatory gene expression, apoptosis, and affecting transcription factor binding (Evans et al. 2004).

The biochemical and molecular mechanisms for the differential coal dust toxicity are poorly understood, but emerging experimental data suggested that some physicochemical characteristics of the coal dusts, such as ROS generation ability, buffering capacity of coal and its acidsoluble $\mathrm{Fe}^{2+}$, are responsible for regional differences in the prevalence of CWP (Vallyathan, et al. 1988; Huang et al. 1998; Aust et a1. 2002). In the present study, we have found that elemental compositions in coal samples with different CWP prevalence were different. In addition, these coal samples have different potencies in generating ROS, inducing oxidative DNA damage and cytokines in human epithelial lung cells. These are in 
accordance with several other in vitro and in vivo studies where different types of mineral particles are shown to vary in their ability to induce pathogenic responses in lung cells (Stringer et al. 1996; Driscoll et al. 1990; Warheit et al. 1995).

CWP is widely believed to be related to oxidative stress (Schins and Borm, 1999). Differences in ROS generating capacities of coal particles were attributed to the concentrations of surface iron in coal mine dust (Dalal et al. 1995). Our results confirmed these findings. Previously, it has been reported that $\mathrm{V}, \mathrm{Pb}, \mathrm{As}$, Ni may also promote ROS generation in vitro and in vivo (Ercal et al. 2001). Bituminous coal samples contained the highest sum of these elements. However, in the present study, bituminous coal sample generates lowest levels of ROS compared with anthracite coal and brown coal samples. In contrast, anthracite coal with the lowest content of $\mathrm{V}$ and $\mathrm{Ni}$ had the highest ROS generating capacities. Furthermore, higher $\mathrm{Cu}$ content in brown and anthracite coals seems to be related to higher release of ROS from coal particles. Copper present in particulate matter shows a major contribution to oxygen radical formation by particulate matter (Shi T et al. 2003). Thus, except for Fe content, it is presumably not the content of other metals that explains the high diversities of ROS generation by different coal samples. But it must also be noticed that our elemental composition determination does not detect the valence of the elements, which plays a crucial role in radical formation via e.g. the Fenton reaction.

Coal dust induced a dose dependent IL-6 production by human airway epithelial cells, suggesting the importance of IL-6 in coal dustinduced pathogenic effects. IL-6 is a multifunctional pleiotropic cytokine involved in the modulation of the immune responses and inflammation (Schins and Borm 1999). Increased levels of IL-6 have been detected in the serum, bronchoalveolar lavage fluid, alveolar macrophages, and in the lungs of pneumoconiotic patients as well as idiopathic pulmonary fibrosis (Zhai et al. 2002; Vallyathan et al. 2000; Vanhee et al. 1995). The increased expression of IL-6 mRNA by alveolar macrophages (AMs) has been confirmed in other models of occupational lung disease, such as chronic beryllium disease or asbestosis (Bost et al. 1993; Zhang et al. 1993).

In contrast to IL-6 production in cultured human epithelial cells, all coal samples reduced TGF- $\beta$, release in a dose-dependent way. TGF- $\beta$ mainly locates in bronchial epithelial cells in normal human lung (Magnan, et al, 1994). TGF. $\beta$. is a potent immunosuppressive molecule for both T- and B-lymphocytes, being 10,000 times more potent than cyclosporine (Rochester and Elias 1993). Additionally, TGF- $\beta$. is known for its anti-inflammatory properties (Vanhee et al. 1995). Increased TGF. $\beta$. concentrations in the BAL fluid of patients with CWP, as compared to 
the BAL fiuid of nonexposed control supernatants have been reported (Vallyathan et al. 2000). In addition, other studies have demonstrated that TGF- $\beta$. has antifibrotic properties and that its antifibrotic action may be concentration-dependent (Vanhee et al. 1995; Schins and Borm 1999). Moreland et al described a significantly higher concentration of TGF. $\beta$. in normal lung compared to fibrotic scleroderma lung (Moreland et al. 1992). TGF- $\beta$. also induced monocyte production of IL-1 ra (Tumer et al. 1991), a molecular that is known for its ability to prevent the development of silica-induced pulmonary fibrosis in mice (Piguet et al. 1993). Thus, considering the anti-inflammatory capacity of TGF- $\beta$, the observation that TGF- $\beta$ release from BEAS- $2 B$ cells decreased upon coal dust exposure may yield an overall increased inflammatory status which could contribute to the development of pulmonary fibrosis in CWP. And in our study, brown coal induced the largest decrease in TGF. $\beta$.

TNF- $\alpha$. is considered to play a key role in the development of coal dust-induced CWP (Schins and Borm 1999), however, TNF- $\alpha$, release from BEAS-2B cells stimulated by coal dusts as well as LPS and $\mathrm{H}_{2} \mathrm{O}_{2}$ was only occurring at a low rate in the present study. The mechanism for this is not clear. However, it has been reported that the epithelial lung cell is not a major source of TNF- $\alpha$ (Rochester and Elias 1993). For example, it was reported that neither swine dust nor LPS, powerfull stimuli for monocytes/macrophages and other cells to release cytokines such as TNF- $\alpha$ or IL-1, induced IL-1 $\beta$ or TNF- $\alpha$ release from epithelial cell line (A549) (Wang et al. 1996; Wang et al. 1999). Similarly, incubation of human lung epithelial cells (SAEC and BEAS-2B) with chromium and manganese at concentrations ranging from 0.2 to $200 \mu \mathrm{M}$ can induce release of inflammatory cytokines IL-6 and IL-8, while no release of TNF- $\alpha$ was observed (Pascal and Tessier. 2004). BEAS-2B cells cultured with total incinerator fly ash (IFA) could induce cytotoxicity and IL-8 release in a dose-dependent manner, but was nearly unable to induce TNF- $\alpha$ release (Diabate et al. 2002). Another study also confirms that carcinoma epithelial cell lines do not produce TNF- $\alpha$ (Spriggs et al. 1988).

Generation of ROS on coal dust was inversely related to coal particleinduced IL-6 release in human epithelial cells. In vitro studies have demonstrated the involvement of ROS in the inflammation and toxic responses after particle exposure (Ghio et al. 1992). Depletion of intracellular antioxidants such as glutathione is associated with the augmentation of oxidative stress-mediated inflammatory state in a ROSdependent mechanism (Haddad JJ. 2002). However, a recent study reported that particle-induced oxidant generation was neither necessary nor sufficient for the induction of inflammatory cytokines in human 
alveolar macrophages. The increased production of IL-6 was suggested to be a result of activation of several other pathways, both ROS-dependent and independent (Mondal et al. 2000). On the other hand, it has been found that ROS, such as S-nitroso-N-acetyl-D, L-penicillamine (SNAP, 100 microM), 3-morpholinosydnonimine (SIN-1, 100 microM), and peroxynitrite (ONOO-, 10 microM) significantly downregulated LPS and/or IL-1 beta induced IL-6 gene expression in human chondrocytes (Mathy-Hartert et al. 2003). ROS has been considered an activator of transcription factor, nuclear factor kappaB (NF-kappaB), which regulates inflammatory cytokine gene expression. It has been shown that inhibitory NF- kappaB (IkappaB-alpha)/NF- kappaB pathway is redox-sensitive but differentially involved in regulation redox-dependent regulation of cytokines (Haddad JJ. 2003).

Although our data confirmed that coal dusts could cause increased oxidative DNA damage in BEAS-2B cells, we could not find a relation between ROS generating capacities of the coal dusts and levels of oxidative DNA damage in BEAS-2B cells. Moreover, ROS generating capacities were not paralleled to DNA damage measured by 8 -oxo-dG/dG ratios or DNA single strand breaks detected with the comet assay in BEAS-2B cells. The discrepancies between ROS generation and oxidative DNA damage should be evaluated in the context of some aspects of our study. Firstly, production of ROS by coal dust involves non-cellular and cellular sources (Vallyathan et al. 1998), in this study, we did not detect cellular ROS generation, thus the extent to which ROS are generated from coal dusts were underestimated. Secondly, besides 8oxodG/dG ratio and DNA strand break, biomarkers of ROS-induced DNA damage may include oxidative modification of DNA, sequence changes, poly-ADP-ribosylation, activation of kinases, point mutation, and chromosomal aberrations (Vallyathan et al. 1998). Analyzing multiple DNA damage biomarkers may more clearly illustrate a relationship between ROS levels and oxidative DNA damage.

In summary, our study shows that the elemental composition, ROS release capacities, and the ability causing oxidative DNA damage were different between brown, bituminous and anthracite coals. Oxidative DNA damage correlated with CWP. Furthermore, differences in cytokine production potency between the three coal dusts were demonstrated, but were not related to CWP Furthermore, the observed different physicochemical properties of the coal dusts were not related to the differences in the prevalence of CWP between different coalmines. This indicates that some other inherent characteristics of the coal dust are crucial for the induction of oxidative DNA damage and correspondingly, with the development of CWP. 


\section{Chapter 8}

\section{Summary and general discussion}

Pneumoconiosis induced by inhalation of mineral dusts such as coal dust, silica, and asbestos is still prevalent in industrial countries, and presents an even greater problem in developing nations (Rosenman KD, 1997; Wagner GR, 1997; Banks DE, 1998). Although mineral dusts are the causative agents of pneumoconiosis, only some people similarly exposed to mineral dusts develop pneumoconiosis, and the determinants of susceptibility are poorly understood. Intrinsic factors such as genetic background may be important determinants of interpersonal susceptibility to pneumoconiosis. (Marshall RP, 1997; Nemery B, 2001; Borm PJA, 2001). However, specific genetic factors in the development of pneumoconiosis have not been clearly identified.

In the past years, many new insights on the mechanisms and mediators in mineral dust-induced lung disorders have been obtained from in vitro studies, animal studies, and epidemiological studies. Although notable differences exist between different types of mineral dusts, in vitro as well as in wivo research has yielded considerable similarities in the nature of biological responses, and in spite of their morphological differences, many different dusts share common endpoints including fibrogenesis. Both coal dust and silica particle can stimulate production of oxidants, and cytokines from a number of cell types. Several of these factors may act alone or in concert to cause chemotaxis, cell injury, proliferation, and synthesis of collagen (Mossman BT, 1998; Schins RFP, 1999). On the other hand, it is now evident that polymorphisms have been found in many genes, including cytokine genes and antioxidant genes. These polymorphisms may be associated with altered susceptibility to disease, to disease severity, and to the response to treatment.

In the present thesis, we explored biomarkers for susceptibility to pneumoconiosis on DNA level (genotypes) and protein level (phenotypes). Focusing on cytokines and antioxidants, the two mostly appreciated biological mechanisms involving in the pathogenesis of pneumoconiosis, we studied the representative cytokines (TNF- $\alpha$, IL-6, TNF- $\alpha$, receptors, IL-6 receptor, and IL-8), oxidant-induced effects (ROS, oxidative DNA damage, DNA strand breaks) and antioxidants (GSTML, 
GST1, MnSOD, OGG1), respectively.

In Chapter 2, we investigated the G-to-A transition polymorphisms at -238 and -308 of the TNF promoter gene in coal miners. Our results showed that frequency of $A^{-308}$ genotype (T2) is significantly overpresented in coal miners with CWP (50\%), as compared with miners without CWP (25\%) and controls (29\%). After correction for cumulative dust exposure and smoking, the $\mathrm{A}^{-308}$ genotype is still associated with the presence of $\mathrm{CWP}(\mathrm{OR}=3.0,95 \%, \mathrm{CI}=1.0-9.0)$. Both $\mathrm{A}^{-308}$ and $\mathrm{A}^{-238}$ genotype were related to TNF release from endotoxin-stimulated blood monocytes; only the $A^{-238}$ genotype and not the $A^{-308}$ genotype was associated with coal dust-induced TNF release. This sturly shows that $A^{-}$ ${ }^{308}$ genotype is related to CWP development, but this relation is not paralleled by a different $\mathrm{TNF}$ release in this genotype.

IL -6 has been implicated in the pathogenesis of silicosis and CWP.A functional $G$ to $C$ polymorphism at position -174 of the promoter of the IL-6 gene has been described. Subjects with the $\mathrm{G}$ allele had higher plasma IL-6 levels compared with $C$ allele carriers. To explore the possibility that this IL-6 polymorphism is involved in the pathogenesis of CWP , we examined this polymorphism in a group of coal miners with CWP and compared them with controls consisting of retired coal miners without CWP (Chapter 3). We found that IL-6 polymorphism at -174 is extremely rare in this cohort of Chinese coal miners. Our results suggested that the IL-6 polymorphism at -174 is unlikely to be contributing significantly to disease susceptibility in Chinese populations.

In response to dust-induced $\mathrm{ROS}$, antioxidants such as $\mathrm{MnSOD}$, GSTM1, GSTT1, and OGG1 are induced locally in the lungs and systematically in the blood. The genes encoding for MnSOD, GSTM1, GSTT1, and OGG1 have been found to be polymorphic. These polymorphisms may alter the function of the associated antioxidants and thereby influence the amount of oxidative damage in the development or severity of disease status. To investigate the association between genetic polymorphisms of MnSOD, GSTM1, GSTT1, or OGG1 and susceptibility to CWP, we analyzed allelic frequencies of these genes in 259 ex-coal miners who had documented coal mine dust exposure histories (Chapter 4). The results showed that there were no differences in genotype frequency of MnSOD, GSTM1, GSTT1, and OGG1 between miners with CWP and miners without CWP, by logistic regression analysis. Cumulative dust exposures, but not genetic polymorphisms, were associated significantly with the presence of CWP. This study illustrated the complexity of evaluated genetic factors that may contribute to disease outcome in CWP. The polymorphisms studied may have a limited role in the modulation of ROS-induced damage in CWP development. 
In Chapter 5, we investigated whether systemic TNF- $\alpha$ soluble TNF$\alpha$ receptors ( $p 55, \mathrm{p} 75), \mathrm{IL}-6$ and soluble $\mathrm{IL}-6$ receptor could be markers of biological activities of CWP. Mean serum concentrations of $\mathrm{p} 55, \mathrm{p} 75$, and IL-6 were significantly higher in CWP cases than in controls. Results from logistic regression models showed similar associations between soluble p55 and p 75 levels and the presence of CWP. Linear regression analysis revealed that CWP radiographic stage was significantly correlated with individual serum concentrations of p55, p75, and IL-6. Serum levels of all measured cytokines were not correlated to age, dust exposure, or smoking, but there were correlations between p 75 and p55, and between $p 75$ and IL- 6 levels. The results suggested that serum levels of TNF receptors and IL-6 are associated with the fibrotic process of CWP and serum cytokine levels may be correlated with the severity of CWP.

Although silicosis is widely known to be characterized with a persistent inflammatory response and generation of pro-inflammatory and fibrotic mediators (Mossman and Churg, 1998; Vanhee et al., 1995; Schins and Borm, 1999; Zhai et al., 2002), it is still uncertain which mechanisms are crucial to the processes of inflammation and fibrogenesis in silicosis. Chapter 7 investigated the cellular and cytokine profiles in bronchoalveolar lavage fluids (BALF) of 16 silicosis patients and compared these with bagassosis. We found that the predominant cell in the BALF in silicosis was macrophages while bagassosis was characterized with hypercellularity with neutrophilia in BALF. Compared with control subjects, increased TNF- $\alpha$, IL-1 $\beta$, IL-8, and IL-6 levels were found in the BALFs in both silicosis and bagassosis. Furthermore, IL-6 levels in the BALF of silicosis subjects were significantly higher than that seen in bagassosis. In contrast, bagassosis had higher level of IL-8 in BALF than that in silicosis. Associations were found between IL-8 levels and neutrophils, lymphocytes and $I L-1 \beta$. in bagassosis, macrophages and $I L-1 \beta$. in silicosis. No significant differences of total protein concentrations and $I L-5$ in BALF were found between controls or bagassosis, and silicosis. The findings of this study indicate that even though silicosis and bagassosis share many similarities in inflammation and fibrosis, their cellular and inflammatory cytokine patterns in the airways are different.

It has been shown that the prevalence and severity of CWP differed remarkably between different coalmines despite comparable exposure to respirable dust (Hurley et al, 1982; Attfield and Castellan, 1992; Amoudru, 1987; Reisner and Robock, 1977). The major factors responsible for the observed regional differences in CWP prevalence have not yet been clearly understood. Chapter 8 studied three coal samples with different CWP prevalence for the content of elements, ROS release capacities, and oxidative DNA damage and cytokine production in human lung epithelial 
cells. Our data showed that metal compositions differed between these three coal samples. Coal dusts which contained a higher content of iron, generally released more ROS than coal samples with less iron content. Exposure of the human lung epithelial cell line (BEAS-2B) to three coal particles induced different oxidative DNA damage levels and cytokine (TNF- $\alpha$, IL-6, TGF- $\beta$ ) release rates. Oxidative DNA damage was correlated to CWP prevalence, however, other physicochemical properties of these coal dusts did not associate with the prevalence of CWP. The results of this study indicate that some other mechanisms than metal composition, clust-induced ROS formation, and cytokine production are of more relevance with respect to the regional differences in the prevalence of CWP.

Overall, although the studies presented in this thesis provide a lot of information on genotypic and phenotypic risk factors associating to the development of mineral dust-induced CWP and silicosis, no final conclusion can be drawn regarding the relationship between genotypes, phenotypes and susceptibility to pneumoconiosis. Our studies illustrate the complexity of pathogenesis of pneumoconiosis. As environmental exposure is the primary determining factor in the incidence of pneumoconiosis, the fact that both exposure and the presence of disease can affect the phenotypic marker must be taken into consideration. There is increasing evidence that several genes influence the development of pneumoconiosis. In a complex polygenic disease such as pneumoconiosis it is likely that multiple genes are operating and that the influence of each gene in isolation may be relatively weak. The susceptibility to develop pneumoconiosis, whether CWP or silicosis, is likely to depend on the coincidence of many gene polymorphisms that act together. Pneumoconiosis thas several components including abnormal immune response, protease/antiprotease interactions, growth factor metabolism, and impaired collagen turnover (Marshall et al, 1997). There are therefore many possible candidate genes but so far few polymorphisms have been studied in relation to pneumoconiosis.

The effects of gene-environmental interactions on disease are further complicated by both the number of genetic loci that are involved, exposure variables (dose, length exposure), other environmental exposure and the presence of etiologic heterogeneity. The issue of confounders is also a major problem in the assessment of gene-environment interactions. Unmeasured genetic determinants and environmental exposures can each act as confounders. Using new technologies such as gene chip technology it is possible to investigate more than 10,000 gene polymorphisms simultaneously, thus providing insight into the complexity of genefunction relationships by gene expression analysis (Brown and Botstein, 
1999). A complementary approach is to search for new genes and proteins by mRNA differential display or proteomics. Identification of genetic and phenotypic markers that predict the prevalence, or that are associated with response to different treatments as they are developed, may help in disease prevention and improved management in the future. 


\section{References}

Aderka $D$, Engelmman $H$, Maor $Y$, Brakebusch $C$, Wallach $D$. Stabilization of the bioactivity of tumor necrosis factor by its soluble receptors. J Exp Med, 1992; 175: 323-329.

Aderka D, Le J, Vilcek J. IL-6 inhibits lipopolysaccharide-induced tumor necrosis factor production in cultured human monocytes, U937 cells, and in mice. J Immunol, 1989, 143: 3517.

Amadis Z, Timlar T. Studies on the effect of quartz, bentonite and coal dust mixtures on macrophages in vitro. Br J Exp Pathol, 1978, 59: 411-419.

Ambrosone CB, Freudenheim JL, Thompson PA. Manganese superoxide dismutase (MnSOD) genetic polymorphisms, dietary antioxidants, and risk of breast cancer. Cancer Res, 1999, 59: $602-606$.

American Thoracic Society. Adverse effects of crystalline silica exposure. Am J Respir Critc Care Med, 1997, 155: 761-765.

Amoudru C. Pneumoconiosis-actual dimensions of the problem. In: Le Bouffant L, editor, Silicosis and mixed-dusts pneumoconiosis. Paris: Colloque INSERM, 1987, 155: 3-40.

Attfield MD. British data on coal miners' pneumoconiosis and relevance to US conditions. Am J Public Health, 1992b, 82: 978-983.

Attfield MD, Castellan RM. Epidemiological data on US coal miners" pneumoconiosis, 1960 to 1988. Am J Public Health, 1992, 82: 964-970.

Attfield MD, Morring K. An investigation into the relationship between coal workers' pneumoconiosis and dust exposure in US coal miners. Am Ind Hyg Assoc J, 1992c, 53: 248-255.

Attfield MD, Seixas NS. Prevalence of pneumoconiosis and its relationship to dust exposure in a cohort of US Bituminous coal miners. Am J Ind Med, 1995d, 27: 137-151.

Attfield MD, Wagner G. Respiratory disease in coal miners. In: Rom WN, ED. Environmental and Occupational Medicine, $2^{\text {nd }}$ edition. Little, Brown and Company, Boston, 1992a, pp.325344.

Aust AE, Ball JC, Hu AA, Lighty JS, Smith KB, Straccia AM, Veranth JM, Yong WC. Particle characteristics responsible to effects on human lung epithelial cells. Res Rep Health Eff Inst, 2002, Dec: $1-65 ; 67-76$.

Bagli M, Papassotiropoulos A, Knapp M, Jessen F, Luise Heun R. Association between an interleukin-6 Promoter and $3^{\prime}$ flanking region haplotype and reduced Alzheimer's disease risk in a German population. Neurosci Lett, 2000, 283: 109- 
112.

Banks DE: The world-wide problem of occupational lung disease. In

Occupational Lung Disease: An International Perspective. Edited by Banks DE, Parker JC. London: Chapman and Hall; 1998: 3-16.

Barton BE, Jackson JV. Protective role of interleukin-6 in the

lipopolysaccharide-galactosamine septic shock model. Infect Immun, 1993, 6: 1496.

Baeuerler PA, Henkel T. Function and activity of NF- $\mathrm{kB}$ in the immune system. Annu Rev Immunol, 1994, 12:141-179.

Bennett JG, Dick JA, Kaplan YS, Shand PA, Shennan DH, Thomas DJ, Washington JS. The relationship between coal rank and the prevalence of pneumoconiosis. Br J Ind Med, 1979, 36: 206210.

Bienkowski RS, Gotkn MG. Control of collagen deposition in mammalian lung. Proc Soc Exp Biol Med, 1995, 209: 118140.

Blackford JA, Jones W, Dey RD, Castranova V. Comparison of inducible nitric oxide synthase gene expression and lung inflammation following intratracheal instillation of silica, coal, carbonyl iron or titanium dioxide in rats. J Toxicol Appl Pharmacol, 1991, 107: 350-368.

Boiteux S, Radicella JP. Base excision repair of 8-hydroxyguanine protects DNA from endogenous oxidative stress. Biochem 1999, 81: 59-67.

Borm PJA, Palmen N. Engelen JJM. Buurman WA. Spontaneous and stimulated release of tumor necrosis factor-alpha (TNF) from blood monocytes of miners with coal workers' pneumoconiosis. Am Rev Respir Dis, 1988, 138: 1589-1594.

Borm PJA, Schins RPF. Derhaag THJM, Kant IJ, Jorna THJM. Crossshift changes in blood inflammatory markers occur in the absence of airway obstruction in workers exposed to grain dust. Chest, 1996, 109: 1078-1085.

Bost $T$, Newman L, Riches D. Increased TNF-alpha and mRNA expression by alveolar macrophages in chronic beryllium disease. Chest, 1993, 103: 138.

Bouma $G$, Crusius JBA, Pool MO, Kolkman JJ. Von Blomberg BME, Kostense PJ, Giphart MJ, Schreuder GMTH, Meuwissen SG, Pena AS. Secretion of tumor necrosis factor- $\alpha$ and lymphotoxin in relation to polymorphisms in the TNF genes and HLA-DR alleles. Relevance for inflammatory bowel disease. Scand J Immunol, 1996, 43: 456-463.

Brigham KL. Role of free radicals in lung injury. Chest, 1980, 89: 
859-863.

Borm PJA., Bast A, Wouters EFM, et al. Red blood cell anti-oxidant parameters in healthy elderly versus silicosis patients. Free Rad Res Comm 1986, 3: 117-127.

Brinkman BMN, Huizinga TWJ, Kuban SS, Van de Velde EA, Hazes JMW, Breedveld FC, Verweij VL. TNFa polymorphisms in RA: Association with susceptibility to, or severity of disease? Eur Cytokine Network, 1996, 7: 177.

Brown GM, Donaldson K, Brown DM. Bronchoalveolar leukocyte response in experimental silicosis: modulation by soluble aluminum compound. Toxicol Appl Pharmacol, 1989, 101: 95-105.

Brown $\mathrm{PO}_{s}$ Botstein D. Exploring the new world of the genome with DNA microarrays. Nat Genet, 1999, 21:33-37.

Cantin AM., Larivee P, Bégin R. Extracellular glutathione suppresses human lung fibroblast proliferation. Am J Respir Cell Mol Biol 1990, 3: 79-85.

Carrol MC, Katzman P, Alicot EM, Koller BH, Geraghty DE, Orr HT, Strominger JL, Spies T. Linkage map of the human major histocompatibility complex including the tumor necrosis factor genes. Proc Natl Acad Sci, USA, 1987, 84: 8535-8539.

Castranova V, Antonin JM, Reasor MJ, Wu L, Van Dyke K. Oxidant release from pulmonary phagocytes. In: Silica and Silicainduced Lung Diseases. Boca Raton, FL: CRC Press, 1996, pp. 345-381.

Castranova V, Bowman L, Reasor MR, Lewis T, Tucker J, Miles PR. The response of rat alveolar macrophages to chronic inhalation of coal dust and/or diesel exhaust. Environ Res, 1985, 36: 405419.

Castranova V. Particles and the airways: basic biological mechanisms of pulmonary pathogenicity. Appl Occup Environ Hyg, 1998, 13:613-616.

Castranova V, Vallyathan V. Silicosis and coal workers' pneumoconiosis. Environ Health Perspect, 2000, 108, suppl. 675-683.

Chen CY, Wang YF, Huang WR, Huang YT. Nickel induces oxidative stress and genotoxicity in human lymphocytes. Toxicol Appl Pharmacol, 2003, 189: 153-159.

Chen Q, Marsh J, Ames B, Mossman B. Detection of 8-oxo -2'deoxyguanosine, a marker of oxidative DNA damage, in culture medium from human mesothelial celis exposed to crocidolite asbestos. Carcinogenesis, 1997, 17: 2525-2527.

Chevillard S, Radicella JP, Levalois C, et al. Mutations in OGG1, a gene involved in the repair of oxidative DNA damage, are found 
in lung and kidney tumors. Oncogene 1998; 16:3083-3086.

Choi I, Kang HS, Yang Y, Pyun KH. IL-6 induces hepatic inflammation and collagen synthesis in vivo. Clin Exp Immunol, 1985, 16: 207-210.

Christian RT, Nelson JB. Coal: response of cultured mammalian cells corresponds to prevalence of coal workers' pneumoconiosis. Environ Res, 1978, 15:232-241.

Churg A. The uptake of mineral particles by pulmonary epithelial cells. Am I Respir Crit Care Med, 1996, 154: 1124-1140.

Clayton D, McKeigue PM. Epidemiological methods for studying genes and environmental factors in complex diseases. Lancet, 2001,358: 1356-1360.

Cockcroft A, Lyons JP, Anderson N, Saunders MJ. Prevalence and relation to underground exposure of radiological irregular opacities in south Wales coal workers with pneumoconiosis. Br J Ind Med, 1983, 40: 169-172.

Collado-Escobar MD, Nieto A, Mataran L, Raya E, Martin J. Interleukin 6 gene promoter polymorphism is no associated with ankylosing spondylitis. J Rheumatol, 2000, 27: 1461-1463.

Collins EL, Gillchrist JC. Effects of dust upon coal trimmers. J Ind Hyg Toxicol, 1928, 10: 101-109.

Cotes JE, Steel J, Leathart GL. Work related lung disorders. Blackwell Sci Publ, Oxford, 1987, pp. 436.

Crawford NP, Bodsworth FL, Dodgson J. A study of apparent anomalies between dust levels and pneumoconiosis at several British collieries. Ann Occup Hyg, 1982, 26: 725-744.

CromwellO, Hamid Q, Corrigan CJ, Barkans J, Meng Q, Collins PD.. Expression and generation of interleukin-8, IL-6 and granulocyte-macrophage stimulating factor by bronchial epithelial cells and enhancement by $\llbracket \mathrm{L}-1 \mathrm{C}$, and tumor necrosis factor $\alpha$. Immunology, 1992, 77:330-337.

Cullen MR, Cherniak MG, Roesenstock L. Medical progress.

Occupational Medicine. N Eng J Med, 1990, 322: 594-601.

Dalal NS, Jafari B, Vallyathan V, Green FHY. Cytotoxicity and spectroscopic investigations of organic-free radicals in fresh and stale coal dust. In: Proceedings $7^{\text {th }}$ international pneumoconiosis Conference. Part 2. 23-26 August 1988, Pittsburgh, Pennsylvania, NIOSH Publ 90-108. Cincinnati. $\mathrm{OH}$ : National Institute for Occupational Safety and Health, 1990, 1470-1477.

Dalal NS, Newman J, Pack D, Leonard S, Vallyathan V. Hydroxyl radical generation by coal mine dust: possible implication to coal workers' pneumoconiosis (CWP). Free Radic Biol Med, 
1995, 18: 11-20.

D'Alfonso S, Momiglianl R.P. A polymorphic variation in a putative regulation box of the TNFA promoter region. Immunogenetics, 1994; 3: 150-154.

De Kok, T.C.M.C., Ten Vaarwerk,F.J., Zwingman,I., Van Maanen,J.M.S. and Kleinjans J.C.S. Peroxidation of linoleic, arachidonic and oleic acid in relation to the induction of oxidative DNA damage and cytogenetic effects. Carcinogenesis, 1994,15: 1399-1404.

De Kossodo S, Critico B, Grau GE. Modulation of the transcripts of tumor necrosis factor-a in vivo. Eur J Immunol, 1994, 24: 769-772.

Denis M. Interleukin 6 in mouse hypersensitivity pneumonitis: changes in lung free cells following depletion of endogenous IL-6 or direct administration of IL-6. J Leukoc Biol, 1992, 52: 197201.

Denis M, Bedard M, Laviolette Cormier Y. A study in monokine release and natural killer activity in the bronchoalveolar lavage of subjects with farmer's lungs. Am Rev, Respir Dis, 1993, 147: 934-939.

De Vuyst P, Camus P. The past and present of pneumoconiosis. Curr Opin Pulm Med, 2000, 6: 151-156.

Diabate S, Mulhopt S, Paur HR, Wottrich R, Krug HF. In vitro effects of incinerator fly ash on pulmonary macrophages and epithelial cells. Int J Hyg Environ Health, 2002, 204:323-326.

Dinarello CA. Inflammatory cytokines: interleukin-1 and tumor necrosis factor as effector molecules in autoimmune diseases. Curr Opin Immuno, 1991, 13: 941-948.

Ding Y, Gonick HC, Vaziri ND. Lead promote hydroxyl radical generation and lipid peroxidation in cultured aortic endothelial cells. Am J Hypertens, 2000, 13: 552-555.

Dong HY, Buard A, Renier A, Levy F, Saint Etienne L, Jaurand MC. Role of oxygen derivates in the toxicity and DNA damage produced by asbestos on pleural mesothelial cells in vitro. Carcinogenesis, 1994, 15: 1251-1255.

Douglas AN, Robertoson A, Chapman JS, Ruckley VA. Dust exposure, dust recovered from lung and associated pathology in a group of British coal miners. Br J Ind Med, 1986, 43: 795801.

Duits AJ, Jainandunsing SM, Van de Winkel GJ, Capal PJA. Selective enhancement of Leu-CAM expression by interleukin- 6 during differentiation of human pro-monocytic U937 cells. Scan J Immunol, 1991, 33: 151-159. 
Driscoll KE, Lindenschmidt RC, Maurer JK. Higgins JM, Ridder G. Pulmonary response to silica or titanium-dioxide: Inflammatory cells, alveolar macrophage-derived cytokines, and histopathology. Am J Respir Cell Mol Biol, 1990, 2: 381-390.

Driscoll KE, Lindenschmidt RC, Maurer JK, Perkins L, Perkins M, Higgins J. Pulmonary response to inhaled silica or titanium dioxide, Toxicol Appl Pharmacol, 1991, 111:201-210.

Dye JA, Adler KB, Richards JH, Dreher KL. Role of soluble metals in oil fly ash-induced airway epithelial injury and cytokine gene expression. Am J Physiol, 1999, 277: L498-L510.

Eckmann L, Kagnoff M, Fierer. Epithelial cells secret the chemokine interleukin- 8 in response to bacterial entry. Infec Immun, 1993, 61: 4569-4574.

Engelen JJ, Borm PJA, van Sprundel M, et al. Blood -antioxidants parameters at different stages of pneumoconiosis in coal workers. Environ Health Perspect, 1990, 84: 165-172.

Evans MD, Dizdaroglu M, Cooke MS. Oxidative DNA damage and disease: induction, repair and significance. Mut Res, 2004, 567: 1-61.

Evelo C T, Bos RP, Borm PJA. Decreased glutathione content and glutathione S-transferase activity in red blood cells of coal miners with early stages of pneumoconiosis. Brit J Ind Med, 1993, 50: 633-636.

Ferris BG. Epidemiology standardized project. Am Rev Respir Dis. 1978, 118s: $1-120$.

Fishman D, Faulds G, Joffory R, Mohamed Adi V, Yudkin JS, Humphries $S$, Woo $P$. The effect of novel polymorphisms in the interleukin 6 (IL-6) gene on IL-6 transcription and IL-6 levels, and association with systemic-onset juvenile chronic arthritis. J Clin Invest, 1998, 102: 1369-1375.

Fogelmark B, Sjostrand M, Rylander R. Pulmonary inflammation induced by repeated inhalation of (1-3-b-D-glucan and endotoxin). Int J Exp Pathol, 1994, 75: 85-90.

Fong $\mathrm{CL}$, Siddiqui AH, Mark DF. Identification and characterization of a novel repressor site in the human tumor necrosis factor- $\alpha$. gene. Nucleic Acids Res, 1994, 22: 1108-1114.

Fournier E, Tornel AB, Gosset PH, Vallaert B, Ameisen JC, Voisin C. Early neutrophil alveolitis after antigen inhalation in hypersensitivity pneumonitis. Chest, 1985, 88: 563-566.

Francois P, Prevost J, Courtois G, Mas A. Pneumoconiosis of delayed apparition: large scaled screening in a population of retired coal miners of the northern coal fields of France. In: 
Proceedings of the VIIIth International Pneumoconiosis Conference, Pittsburgh, Pennsylvania, USA, NIOSH, 90-108 part II, 1988, pp. 979-984.

Frasca JM, Auerbach O, Carter HW. Morphologic alterations induced by short-term cigarette smoking. Am J Pathol, 1983, 111: 11-20.

Fubini $B$ and Mollo $L$. Role of iron in the reactivity of mineral fibers.

Toxicol Lett, 1995, 82/83: 951-960.

Fujumura N. Pathology and pathophysiology of pneumoconiosis. Curr Opín Pulm Med, 2000, 6: 140-144.

Garcia-Merino A, Alper CA, Usuku k, Marcus-Bagley D, Lincoln R. nis EJ, Eisenbarth GS, Brink SJ, Hauser SJ. Tumor Necrosis factor (TNF) microsatellite haplotypes in relation to extended haplotypes, susceptibility to diseases associated with the major histocompatibility complex and TNF secretion, Hum Immunol, 1996, 50:11-21.

Gauldie J, Jordana M, Cox G. Cytokines and pulmonary fibrosis. Thorax, 11993, 48: $931-935$.

Gautrin D, Auburtin G, Alluin F, Brice FM, Chouraki B, Francois F, Marquet M, Poure C, Senecot B, Szmacinski R, Vandeweghe $\mathrm{S}$, Sebastien $\mathrm{P}$. Recognition and progression of coal workers' pneumoconiosis in the colleries of northern France. Exp Lung Res, 1994, 20: 395-410.

Ghio AJ, Kennedy TP, Whorton AR, Crumblias AL, Hatch GE, Hoidal

JR. Role of surface complexed iron in oxidant generation and lung inflammation induced by silicates, Am J Physiol, 1992, 263: L511-L518.

Gosset P, Lassalle P, Vanhee D, Wallaert B, Aerts C, Voisin C, Tonnel A.

Production of tumor necrosis factor-alpha and interleukin-6 by human alveolar macrophages exposed in vitro to coal mine dust. Am J Respir Cell Biol, 1991, 5: 431-436.

Gough J. Pneumoconiosis in coal trimmers. J Pathol Bacteriol, 1940, 51: 277-285.

Greaves IA. Not-so-simple silicosis: A case for public health action. Am J Ind Med, 2000, 37: 245-251.

Green FHY, Vallyathan V. Coal workers' pneumoconiosis and pneumoconiosis due to other carbonaceous dusts. In: Pathology of Occupational Lung Disease. $2^{\text {nd }}$ ed (Churg A, Green FHY eds). Philadelphia: Williams and Wilkins, 1998, 129-208.

Gross P. Pneumoconiosis. In: Parmeggiani L, ED. Encyclopedia of

Occupational Health and Safety, International Labour Office. Geneva 1983, pp.1731-1733.

Haddad JJ. Redox regulation of pro-inflammatory cytokines and IkappaB 
-alpha/NF-kappaB nuclear translocation and activation. Biochem Biophys Res Commun; 2002, 296:847-56.

Hamann A, Mantxoroe C, Vidal-Puig A, Flier IS. Genetic variability In the TNF- $\alpha$ promoter is not associated with type II diabetes mellitus (NLDDM). Biochem Biophys Res Commun, 1995, 211: 833-839.

Han J, Brown T, Beutler B. Endotoxin-responsive sequences control cachectin/tumor necrosis factor biosynthesis at the translational level. J Exp Med, 1990, 171: 465-475.

Hardie LJ, Briggs JA, Dadidson LA, et al. The effect of hOGGl and glutathione peroxidase I genotypes and $3 p$ chromosomal loss on 8-hydroxideoxyguanosine levels in lung cancer. Carcinogenesis, 2000, 21: 167-172.

Heaney ML, Golde DW. Soluble cytokine receptors. Blood, 1996, 87: 847-857.

Hejny H, Robock K, Aembruster L. On the question of quartz evaluation in mine dusts from coal mining and its specific harmfulness. In Results of studies on dust suppression and silicosis prevention in hard coal mining. (Steinkohlenberg-bauverein, Hauptsezernat Staubbekamfung, Ed.), 1989, Vol. 17, p139158.

Hesagawa M, Sato S, Fujimoto M, Ihn H, Kikuchi K, Takebara K. Serum levels of interleukin 6 ( IL-6), oncostatin M, soluble IL-6 receptor, and soluble pg 130 in patients with systemic sclerosis. J Rheum, 1998, 25: 3308-3313.

Hiroi S, Harada H, Nishi H, et al. Polymorphisms in the SOD2 and HLA-DRBI genes are associated with nonfamilial idiopathic dilated cardiomyopathy in Japanese. Bioch Biophy Res Commun, 1999, 261: 332-339.

Hnizdo E, Murray J, Sluis, Cremer GR. Thomas RG. Correlation between radiological and pathological diagnosis of silicosis: An autopsy population based study. Am J Ind Med, 1993, 24: 427-445.

Honda K, Kimura A, Doug LP, Tamai $H, N$ agato $H$, Nishimura $Y$, Sasazuki T. Immunogenetic analysis of silicosis in Japan. Am J Respir Cell Mol Biol, 1993, 8: 1.06-111.

Huang X, Fournier J, Koenig K, Chen LC. Buffering capacity of coal and its acid-soluble $\mathrm{Fe}^{2+}$ content: possible role in coal workers' pneumoconiosis. Chem Res Toxicol, 1998, 722-729.

Huang X, Zalma $R$, Pezerat $H$. Chemical reactivity of the carbon-centered free radicals and ferrous iron in coals: role of bioavailable $\mathrm{Fe}^{2+}$ in coal workers" pneumoconiosis. Free Rad Res, 1999 , 30: 439-451. 
Huzinga TWJ, Westendorp RDJ, Bollen ELEM, Keijsers V, Brinkman BMN, Langermans JAM, Breedveld FC, Verweij VL. De Gaer L, Dams L. Crusius JBA, Garcia-Gonzalet A, van Oosten B w, Polman $\mathrm{CH}$, Pena AS. TNF a promoter polymorphisms, production and susceptibility to multiple sclerosis in different groups of patients. J Neuroimmunol, $1997,72: 149-153$.

Hulkkonen J, Viopo J, Vilpo L, Koski T, Hurme M. Lnterleukin-1 beta, interleukin-1 receptor antagonist and interleukin-6 plasma levels and cytokine gene polymorphisms in chronic lymphocytic leukemia: correlation with prognostic parameters. Hematologica, 2000, 85: 600-606.

Hurley JF, Burns J, Copland L, Dogdson J, Jacobsen M. Coal workers" pneumoconiosis and exposure to dust at 10 British coalmines. Br J Ind Med, 1982, 39: 120-127.

Hussey AJ, Hayes JD. Human $\mu$-class glutathione S-transferases present in liver, skeletal muscle and testicular tissues. Biochim Biophys Acta 1993, 1203: 131-141.

International Labour Office. Bagasse. 1983. In: Parmeggiani L, ed. Encyclopedia of Occupational Health and Safety. Vol. 1. $3^{\text {rd }}$ ed. Geneva: ILO 1983: 234-235.

International Labor Office. Guideline for the use of ILO international classification of radiographs of pneumoconiosis. Geneva: Occupational Safety and Health Sciences 1980: 22.

Jacob CO, Fronek Z. Lewis GD, Koo M, Hansen JA, McDevitt HO. Heritable major histocompatibility complex class IIassociated differences in production of tumor necrosis factora: Relevance to genetic predisposition to systemic lupus erythematosus. Proc Natl Acad Sci, USA, 1990, 87: 1233 1237.

Jakobsson K, Rannug A, Alexandrie AK, et al. Genetic polymorphism for glutathione-S-transferase $\mathrm{mu}$ in asbestos cement workers. Occup Environ Med, 1994, 51: 8\2-816.

Janssen YMW, Marsh JP, Driscoll $\mathrm{KE}$, et al. Increased expression of manganese-containing superoxide dismutase in rat lungs after inhalation of inflammatory and fibrotic minerals. Free Radic Biol Med 1994, 16: 315-322.

Jorens PG, Richman-Eisenstat JBY, Housset BP, Massion PP, Ueki I, Nadel JA. Pseudomonas-induced neutrophil recruitment in the dog airway in vivo is mediated in part by IL-8 and inhibited by leumedin. Eur Respir J, 1994, 7: 1925-1931.

Kadiiska MB, Mason RP, Dreher KL, Costa DL, Ghio AJ. In vivo evidence of free radical formation in the rat lung after 
exposure to an emission source air pollution particles. Chem Res Toxicol, 1997, 10: 1104-1108.

Kamp DW, Graceffa P, Pryor W, et al. The role of free radicals in asbestos-induced diseases. Free Radic. Biol. Med, 1992, 12: 293-315.

Kelsey KT, Nelson HN, Wiencke JK, et al. The glutathione S-transferase $\theta$ and $\mu$ deletion polymorphisms in asbestosis. Am J Ind Med 1997, 31: 274-279.

Kleinerman J, Green FHY, Harley R, Lapp NL, Laqueur W, Naeye RL, Pratt P, Taylor G, Wyatt J. Pathology Standards for Coal Workers' Pneumoconiosis: Report of the Pneumoconiosis Committee of the College of American Pathologists to the National Institute for Occupational Safety and Health. Arch Pathol Lab Med, 1978, 103: 375-431.

Kosmidou I, Vassilakopoulos T, Xagorari A, Zakynthinos S,

Papapetropoulos A, Roussos C. production of interleukin-6 by skeletal myotubes: role of reactive oxygen species. Am J Respir Cell Mol Biol, 2002, 26: 587-593.

Kruppa G, Thoma B, Machleidt Y, Wiegmann K, Kronke M. Inhibition of tumor necrosis factor (TNF)-mediated NF-kB activation by selective blockade of the human $55-\mathrm{kDa}$ TNF receptor. J Immunol, 1992, 148: 3152-3157.

Kuchino $\mathrm{Y}$, Mori F, Kasai H, Inoue $\mathrm{H}$, Iwai S, Miura K, Ohtoka E, Nishimura S. Misreading of DNA templates containing 8hydroxydeoxyguanosine at the modified base and at adjacent residues. Nature, 1987, 32, 77-79.

Lapp NL, Morgan WK, Zaldivar G. Airway obstruction, coal mining, and disability. Occup Environ Med 1994; 51: 234-238.

Lasalle P, Gosset P, Aerts C, Fournier E, Lafitte JE, Degreef JM, Wallaert $B$. Tonnel AB, Voisin C. Abnormal secretion of interleukin-1 and tumor necrosis factor-aby alveolar macrophages in coal workers' pneumoconiosis: Comparison between simple pneumoconiosis and progressive massive fibrosis. Exp Lung Res, 1990, 16: 73-80.

Leanderson P, Soderkvist $P$, Tagesson C, Axelson O. Formation of

8-hydroxydeoxyguanosine by asbestos and man made mineral fibers. Brit J Ind Med, 1988, 45: 309-311.

Lee SC, Pu YB, Thomas GN, Lee ZS, Tomlinson B, Cockram CS, et al. Tumor necrosis factor alpha gene G-308A polymorphism in the metabolic syndrome. Metabolism, 2000, 49: 1021-1024.

Lewis AB, Taylor MD, Roberts JR, Leonard SS, Shi X, Antonini JM.

Role of metal-induced reactive oxygen species generation in lung response caused by residual oil fly ash. J Biosci, 2003, 
28: $13-18$.

Liang G, Kang G. Epidemiological study on pneumoconiosis in coal mines in Guangxi. Proceedings of the fourth southern China conference on occupational health, Shanya, China, 1991, p614.

Li DH. Prevention and treatment of pneumoconiosis in the past fifty years": a review. Chin J Ind Hyg Occup Dis, 1999, 17: 258261.

Lister WB, Winborne D. Carbon pneumoconiosis ina synthetic graphite workers. Br J Ind Med, 1972, 29: 108-110.

London SJ, Yuan JM, Chung FL, Gao YT, Coetzee GA, Ross RK, Yu MC. Lsothiocyanates, glutathione S-transferase M1 and T1 polymorphisms, and lung-cancer risk: a prospective study of men in Shanghai, China. Lancet, 2000, 356: 729.

Lyer R, Hamilton RF, Li L, Holian A. Silica-induced apoptosis mediated via scavenger receptor in human alveolar macrophages. Toxicol Appl Pharmacol, 1996, 141: 84-92.

Macnee W. Oxidative stress and lung inflammation in airway disease. Eur J Pharmacol, 2001, 429: 195-207.

Magnan A, Frachon I, Rain B, Peuchmaur M, Monti G, Lenot B, Fattal M, Simonneau G, Galanaud P, Emilie D. Transforming growth factor beta in normal human lung: preferential location in bronchial epithelial cells. Thorax, 1994, 49: 789792.

van Maanen JMS, Borm PJA, Knaapen A, van Herwijnen M,

Schilderman PAEL, Smith KR, Aust AE, Tomatis M, Fubin $B$. In vitro effects of coal fly ashes: hydroxyl radical generation, iron release, and DNA damage and toxicity in rat lung epithelial cells. Inhal Toxicol, 1999, 11: 1123-11.41.

MacNee W. Oxidative stress and lung inflammation in airways disease. Eur J Pharmacol, 2001, 195-207.

Magnan A, Frachon I, Rain B, Peuchmaur M, Monti G, Lenot B, Fattal M, Simonneau $G$, Galanaud P, Emilie D. Transforming growth factor beta in normal human lung: preferential location in bronchial epithelial cells. Thorax, 1994, 49: 789792.

Marshall RP, McNaulty RJ, Laurent GJ. The pathogenesis of pulmonary fibrosis: is there a fibrosis gene? Int J Biochem Cell Biol, 1997, 29: 107-120.

Mathy-Hartert M, Martin G, Devel P, Deby-Dupont G, Pujol JP, Reginster JY, Henrotin Y. Reactive oxygen species downregulate the expression of pro-inflammatory genes by human chondrocytes. Inflamm Res, 2003, 52: 111-118. 
Mattey DL, Hassell AB., Dawes PT, et al. Influence of polymorphism in the manganese superoxide dismutase locus on disease outcome in rheumatoid arthritis. Arthritis Rheum, 2000, 43: $859-864$.

Mayers RA. Coal structure, Academic Press, New York, 1982. McGuire W, Hill AVS, Allsopp CEM. Greenwood BM. Kwiatkowski D. Variation in the TNF-apromoter region associated with susceptibility to cerebral malaria. Nature, 1994, 371: 508-511.

Merchant RK, Peterson MW, Hunninghake GW. Silica directly increases permeability of alveolar epithelial cells. J Appl Physiol, 1990, 68: 1354-1359.

Meyer JD, Holt DL, Chen Y, Cherry NM, McDonald JC. SWORD'99: surveillance of work-related and occupational respiratory disease in the UK. Occup Med, 2001, 51: 204-208.

Miller BG, Jacobsen M, Dust exposure, pneumoconiosis, and mortality of coal miners. Br J Ind Med, 1985, 42: 723-733.

Ministry of Health, People's Republic of China. Bulletin of the National Investigation of Pneumoconiosis (1949-1986), Union Publishing House, Beijing, 1992.

Ministry of Health, People's Republic of China. Methods for airborne dust measurement in workplace (GB/T5748-1985). 1985.

Mohr C. Gensa D, Graebner C, Hemenway DR. Leslie KO. Absher PM.Davis GS. Systemic macrophage stimulation rats with silicosis: Enhanced release of tumor necrosis factor- $\alpha$ from alveolar and peritoneal macrophages. Am J Respir Cell Mol Biol, 1991, 5: 395-402.

Molvig J, Baek L, Christensen P, Manogue KR, Vlassara H, Platz P, Nielsen LS, Svejgaard A, Nerup I. Endotoxin-stimulated human monocyte secretion of interleukin-1, tumor necrosis factor alpha, and prostaglandin E2 shows stable interindividual differences. Scand J Immunol, 1988, 27: 705-712.

Mondal K, Stephea HJ, Becker S. Adhesion and pollution particle induced oxidant generation in neither necessary nor sufficient for cytokine induction in human alveolar macrophages. Am J Respir Cell Mol Biol, 2000, 22: 200-208.

Morgan WKC, Burgess DB, Jacobson G, O'Brien RJ, Pendergrass E,

Reger RB, Shoub EP. The prevalence of coal workers" pneumoconiosis in US coal miners. Arch Environ Health, 1973, 27: 221-230.

Mossman T, Rapid colometric assay for cellular growth and survival: application to proliferation and cytotoxicity assays. J $\mathrm{Imm}$ Meth, 1983, 65: 516-527. 
Mossman BT, Churg A. Mechanisms in the pathogenesis of asbestosis and silicosis. Am J Respir Crit Care Med, 1998, 157: 16661680 .

Murray J, Kielkowski D, Reid P. Occupational disease trends in black South African gold miners. Am J Respir Crit Care Med, 1996, 153: 706-710.

Nakajima T, Ota N, Watanabe S, Suzuki T, Emi M. Allelic variants in the interieukin-6 gene and essential hypertension in Japanese women. Genes Immun, 1999, 1: 115-119.

Nehls T, Seiler F, Rehn B, Greferath R, Bruch J. Formation and persistence of 8-oxoguanine in rat lung cells as an important determinant for tumor formation following particle exposure. Environ Health Perspec, 1997, 105: 1291-1296.

Nef M, Saitou N. Genetic relationship of human populations and ethnic differences in reaction to drugs and food. In: Ethnic differences in reactions to drugs and xenobiotics. Kalow W, Goedde HW, Agarwal DP (editors). New York: Alan R Liss, 1986, pp. 21-37.

$\mathrm{Ng}$ TP, Chan SL. Factors associated with massive fibrosis in silicosis. Thorax, 1991, 46: 229-232.

Oliver JL, Mancini NM., Humbert JC, Chabot F, Jean-Marie Polu. Interleukin-6, interferon-Gamma, and phospholipid levels in the alveolar lining fluid of human lungs: Profiles in coal workers' pneumoconiosis and idiopathic pulmonary fibrosis. Chest, 1994; 106: 407-413.

Ortiz LA, Lasky J, Lungarella $G$, et al. Upregulation of the p75 but not the p55 TNF-alpha receptor mRNA after silica and bleomycin exposure and protection from lung injury in double receptor knockout mice. Am J Respir Cell Mol Bio, 1999, 20: 825-833.

Ortmeyer CE, Baier EJ, Craw ford GM. Life expectancy of Pennsylvania coal miners compensated for disability. Arch Environ Health, $1973,27: 227-230$.

Pardo A, Barrios R, Gaxiola M, Segura-Valdez L, Carrillo G, Estrada A, Mejia $\mathrm{m}$, Selman M. Increase of lung neutrophils in hypersensitivity pneumonitis is associated with lung fibrosis. Am J Respir Crit Care Med, 2000, 161: 1698-1704.

Parker JE, Banks DE. Lung diseases in coal workers. in Occupational Lung Disease (ed. D. E. Banks and J. E. Parker), Chapman \& Hall Medical, 1998, pp. 161-181.

Parkes WR: Occupational Lung Disorders, ed. 3. Oxford, UK:

Butterworth Heinemenn Ltd; 1994: 35.

Pascal LE, Tessier DM. Cytotoxicity of chromium and manganese to lung 
epithelial cells in vitro. Toxicol Lett, 2004, 147:143-51.

Perkins RC, Scheule RK, Hamilton R, Gomes G, Freidman G Holian A.

Human alveolar macrophage cytokine release in response to in vitro and in vivo asbestos exposure. Exp Lung Res, 1993, 19: 555-565.

Perrey C, Pravica V, Sinnott PJ, Hutchinson IV. Genotyping for polymorphisms in interleukin- $\gamma$, interleukin- 10 , transforming growth factor- $\beta 1$ and tumor necrosis factor-a genes: A technical report. Trans Immunol, 1998, 6: 193-197.

Peschon JJ, Torrance DS, Stocking KL, et al. TNF receptor-deficient mice reveal divergent roles for $\mathrm{p} 55$ and $\mathrm{p} 75$ in several models of inflammation. J Immunol, 1998, 160: 943-952.

Piguet PF, Collart MA, Grau GE, Sappino AP, Vassalli P. Requirement of tumor necrosis factor for development of silica-induced pulmonary fibrosis. Nature, 1990, 344: 245-247.

Piguet $\mathrm{PF}$, Vesin $\mathrm{C}$, Grau GE, Thompson RS. Interleukin-1 receptor antagonist (IL-1ra) prevents or cures pulmonary fibrosis elicited by bleomycin or silica. Cytokine, 1993, 5: 57-61.

Piguet PF, Vesin C. Treatment by human recombinant soluble TNF receptor of pulmonary fibrosis induced by bleomycin or sillica in mice. Eur Respir J, 1994; 7: 515-518.

Pilger A, Germadnik D, Schaffer A, et al. 8-hydroxydeoxyguanosine in leukocyte DNA and urine of quartz-exposed workers and patients with silicosis. Int Arch Occup Environ Health, 2000; 73:305-310.

Pocior F, Briant L, Jongeneel CV, Molvig J, Worsaae H, Abbal M, Nerup $\mathrm{J}$, Cambou-Tompsen A. Association of tumor necrosis factor (TNF) and class II major histocompatibility complex alleles with the secretion of TNF-aand TNF- 3 by human mononuclear cells: A possible link to insulim dependent diabetes mellitus. Eur J Immunol, 1993, 23: 224-231.

Pociot F, D'Alfonso S. Compssso S. Scorza R. Richiardi PM. Functional analysis of a new polymorphism in the human TNFapromoter. Scand J Immunol, 1995, 42: 501-504.

Pociot F, Molvig I, Wogensen L, Worsaae $H$, Nerup J. A taq I polymorphism in the human interleukin-1 $\beta$ (1L-1 $\beta$ ) gene correlates with IL- $1 \beta$ secretion in vitro. Eur J Clin Invest, 1992, 22: 396-402.

Pon MRL, Roper RA, Petsonk EL, Wang ML, Castellan RM, Attfield

MD, Wagner GR. Pneumoconiosis prevalence among working coal miners examined in federal chest radiograph surveillance programs-United States, 1996-2002. MMWR, 2003, 52 (15): 336-340. 
Portier M, Lees D, Caron E, et al. Up-regulation of interleukin-6 receptor gene expression in vitro and in vivo in IL-6 derived myeloma cells. FEBS Lett, 1992, 302: 35-38.

Pritchard RU, Ghio AJ, Lehmann JR, Winsett DW, Tepper JS, Park P, Gilmour MI, Dreher KL, Costa DL. Oxidant generation and lung infury after particulate air pollutant exposure increase with the concentrations of associated metals. Inhal Toxicol, $1996,8: 457-477$.

Rahman I, Macnee W. Role of transcription factors in inflammatory lung diseases. Thorax, 1998, 53: 601-612.

Redlich CA: Pulmonary fibrosis and interstitial lung diseases. In Occupational and Environmental Respiratory Disease. Edted by Harber P, Schenker MB, Balmes JR. Saint Louis, Missouri: Mosby; 1996: 216-227.

Reisner MTR, Robock K. Results of epidemiological, mineralogical and cytotoxicological studies on the pathogenicity of coal mine dusts. Oxford, UK, Pergmon Press, 1977, p703-715.

Rihs HP, Lipps P, May-Taube K, Jager D, Sehmidt EW, Hegemann JH, Baur X. Immunogenetic studies on HL.A-DR in German coal miners with and without coal worker's pneumoconiosis. Lung, 1994, 172; 347-354.

Rochester CL, Elias JA. Cytokines and cytokine networking in the pathogenesis of interstitial and fibrotic lung disorders. Seminars Respir Med, 1993, 14: 389-415.

Rom WN, Bitterman PB, Rennard SI, Cantin A, Crystal RG.

Characterization of the lower respiratory tract inflammation of nonsmoking individuals with interstitial lung disease associated with chronic inhalation of inorganic dusts. Am Rev Respir Dis, 1987, 136: 1429-1434.

Rom WN. The discipline of Environmental and occupational medicine.

In: Rom WN, ED. Environmental and occupational medicine, $2^{\text {nd }}$ edition. Little, Brown and Company, Boston, 1992, pp.36.

Rosenman KD, Reilly MJ, Kalinowski DJ, Watt FC: Silicosis in the 1990's. Chest, 1997, 111: 779-786.

Ross MP, Nolan RP, Langer AM, Cooper WC. Health effects of mineral dusts other than asbestos. In Gurthrie JR and Mossman BT, editors. Health Effects of Mineral Dusts. Reviews in Mineralogy. Vol. 28. Mineralogical Society of America, Washington, DC, 361-409.

Salvaggio JE. Extrinsic allergic alveolitis (hypersensitivity pneumonitis): past, present and future. Clinical and Experimental Allergy, 1997, 27: Suppl. 18-25. 
Sandstrom T, Bjermer L, Ragnar R. Lipopolysacehride (LPS) inhalation in healthy subjects increases neutrophils, lymphocytes and fibronectin levels in bronchoalveolar lavage fluid. Eur Respir J, 1992, 5: 992-996.

Sariban E, Imamura K, Leubbers R, Kufe D. Transcriptional and posttranscriptional regulation of tumor necrosis factor gene expression in human monocytes. J Clin Invest, 1988, 81: 1506-1510.

Savici D, He B, Lois JG, Monick MM. Silica increases tumor necrosis factor (TNF) production, in part, by upregulating the TNF promoter. Exp Lung Res, 1994, 20: 613-625.

Schindler R, Mamcilla J, Ghorbani R, Clark SC, Dinarello CA. Correlations and interactions in the production of interleukin6 (IL-6), IL-1, and tumor necrosis factor (TNF) in human blood mononuclear cells: IL-6 suppress IL-1 and TNF. Blood, 1990, 75: 40.

Schins RP, Borm PJ. Mechanisms and mediators in coal dust induced toxicity: A review. Ann Occup Hyg, 1999, 43: 7-33.

Schins RPF, Borm PJA. Epidemiological evaluation of monocyte TNF $\alpha$ release as an exposure and effect marker in pneumoconiosis. A five-year follow up study among coal miners. Occup Environ Med, 1995, 52: 441-450.

Schins RPF, Borm PJA. Epidemiological evaluation of release of monocyte TNF as an exposure and effect marker in pneumoconiosis: Five year follow up study of coal workers. Environ Med, 1995, 52: 441-450.

Schins RPF, Borm PJA. Mechanisms and mediators in coal dust induced toxicity: A review. Ann Occup Hyg, 1999, 43: 7-33.

Schins RPF, Borm PJA. Plasma levels of the tumor necrosis factor (TNF) receptors are increased in coal miners. Eur Respir $J, 1995,8$ : 1685-1663.

Schins PRF, Keman S, Borm PJA. Blood antioxidant status in coal dustinduced respiratory disorders: a longitudinal evaluation of multiple biomarkers. Biomarkers, 1997; 2: 45-50.

Schins PRF, Schilderman PAEL, Borm PJA. Oxidative DNA-damage in peripheral blood lymphocytes of coal workers. Int Arch Occup Environ Health, 1995, 67: 413-419.

Schins RPF, van Hartingsveldt B, Borm PJA. Ex vivo cytokine release from whole blood. A routine method for health effects screening. Exp Toxicol Pathol, 1996, 48: 494-496.

Schulz HM. Coal mine workers' pneumoconiosis (CWP): in vitro study of the release of organic compounds from coal mine dust in the presence of physiological fluids. Environ Res, 1997, 74: 
74-83.

Schwartz MI, Interstitial pulmonary fibrosis. In Kelley WN, ED.

Textbook of Internal Medicine. J. P. Lippincott Co. Philadelphia, 1993, pp. 1902-1905.

Seabury J, Salvaggio T, Buechner H, Kundur VG. Bagassosis. III. Isolation of thermophilic and mesophilic actinomycetes and fungi from moldy bagasse. Proc Soc Exp Biol Med, 1968, $129: 351$.

Selman, M. Hypersensitivity pneumonitis. In M. Schwarz and T. E. King. Editors. Interstitial Lung Disease. Decker Inc. Hamilton. ON. Canada. 1998, 393-422.

Seow A Shi CY, Chung FL. Jiao D, Hankin JH, Lee HP et al. Urinary total isothiocyanate (ITC) in a population-based sample of middle-aged and older Chinese in Singapore: relationship with dietary total ITC and glutathione S-transferase M1/T1/PI genotypes. Cancer Epidemiol Biomarkers Prev, 1998, 9: 775-781.

Shennan DH, Washington JS, Thomas DJ, Dick DJ, Kaplan YS, Bennett JG. Factors predisposing to the development of PMF in coal miners. Br J Ind Med, 1981, 38: 321-326.

Sherwin RP, Bowman ML, Abraham JL. Silicate pneumoconiosis in farm workers. Lab Invest, 1979, 40: 576-582.

Shi T, Schins RP, Knaapen AM, Kuhlbusch T, Pitz M, Heinrich J, Borm PJ. Hydroxyl radical generation by electron paramagnetic resonance as a new method to monitor ambient particulate matter composition. J Environ Monit. 2003, 5: 550-6.

Shi X, Dalal NS, Vallyathan V. ERS evidence for the hydroxyl radical formation in aqueous suspension of quartz particles and its possible significance to lipid peroxidation in silicosis. J Toxicol Environ Health, 1988, 25: 237-245.

Silicosis and Silicate disease Committee. Diseases associated with exposure to silica and nonfibrous silicate minerals. Archive Pathol Lab Med, 1988, 112: 673-719.

Singh NP, McCoy MT, Tice RR, Schneider EL 1988 A simple technique for quantization of low levels of DNA damage in individual cells. Exp Cell Res. 1988,175: 184-91.

Singh SV, Rahman Q, Interrelationships between hemolysis and lipid peroxidation of human erythrocytes induced by silicic acid and silicate dust. J Appl Toxicol, 1987, 7:91-96.

Soutar CA. Update on lung disease in coal miners. Br J Ind Med, 1987, 44: $145-148$.

Spriggs DR, Imamura K, Rodriguez C, Sariban E, Kufe DW. Tumor necrosis factor expression in human epithelial tumor cell 
lines. J Clin Invest, 1988, 81: 455-469.

Strieter RM, Kasahara K, Allen RM, Standiford TJ, Rolfe MW, Becker

FS, Chensue SW, Kunkei SL. Cytokine-induced neutrophilderived interleukin-8. Am J Pathol, 1992, 141: 397-407.

Sugimura H, Kohno T, Wakai K, Nagura K, Genka K, Igarashi H et al. HOGG1 Ser326Cys Polymorphism and Lung Cancer Susceptibility. Cancer Epidemiol Biomarkers Prev, 1999, 8: 669-674.

Sun Y, Obserley LW. Redox regulation of transcriptional activators. Free

Radic Biol Med, 1996, 21335-21348. Tartagla LA, Weber RF, Figari IS, Reynolds C, Palladdino MA, Goeddel DV. The two different receptors for tumor necrosis factor mediate distinct cellular responses. Proc Natl Acad Sci USA, 1991, 88: 92929296.

Taga T, Hibi M, Hirata Y, et al. Interleukin- 6 triggers the association of its receptor with a possible signal transducer, pg 130. Cell, 1989, 58: $573-581$.

Thannickal VJ, Toews GB, White ES, Lynch III JP, Martinez FJ.

Mechanisms of pulmonary firbrosis. Annu Rev Med, 2004, 55: 395-417.

Thorn J, Beijer L, Rylander R. Airways inflammation and glucan exposure among household waste collectors. Am J Ind Med, 1998, 33: 463-470.

Tice RR, Agurell E, Anderson D, Burlinson B, Hartmann A, Kobayashi H, Miyamae Y, Rojas E, Ryu JC, Sasaki YF., Single cell gel/comet assay: guidelines for in vitro and in vivo genetic toxicology testing. Environ Mol Mutagen, 2000, 35: 206-21

Tilg H, Trehu E, Atkins MB, Dinarello CA, Mier JW. Interlleukin-6 (IL-6) as an anti-inflammatory cytokine: induction of circulating IL-1 receptor antagonist and soluble tumor necrosis factor receptor p55. Blood, 1994, 83: 113-118.

Ulich TR, Yin S, Guo K, Yi ES, Remick D, Castillo J. Intratracheal injection of endotoxin and cytokines. II. Interleukin-6 and transforming growth factor beta inhibit acute inflammation. Am J Pathol, 1991,138: 1097-1101.

Vallyathan V, Brower PS, Green FH, Attfield MD. Radiographic and pathologic correlation of coal worker's pneumoconiosis. Am J Respir Crit Care Med, 1996, 154: 741-748.

Vallyathan V. Generation of oxygen radicals by minerals and its correlation to cytotoxicity. Environ Health Perspect, 1994, 102 (suppl 10): 111-115.

Vallyathan V, Goins M, Lapp LN, et al. Changes in bronchoalveollar lavage indices associated with radiographic classification in 
coal miners. Am J Respir Crit Care Med, 2000, 162: 958-65.

Vallyathan V, Mega JF, Shi X, Dalal NS. Enhanced generation of free radicals from phagocytes induced by mineral dusts. Am J Respir Cell Mol Biol, 1992, 6: 404-413.

Vallyathan V, Schwegler D, Reasor M, Settler L, Green FHY.

Comparative in vitro cytotoxicity and relative pathogenicity of mineral dusts. Ann Occup Hyg, 1988, 32; 279-289.

Vallyathan V, Shi X, Dalal NS, Irr W, Castranova V. Generation of free radicals from freshly fractured silica dust. Potential role in acute silica-induced lung injury. Am Rev Respir Dis, 1988, 138: $1213-1219$.

Vallyathan V, Shi X. The role of oxygen free radicals in occupational and environmental. lung diseases. Environ Health Perspect, 1979, 105: $165-176$

Vallyathan V, Xianglin Shi, Castranova V. Reactive oxygen species: Their relation to pneumoconiosis and carcinogenesis. Environ Health Perspect, 1998, 106 (Suppl): 1151-1155.

Vallyathan van, Goins $M$, Lapp $\mathbb{L N}$, Pack N, Leonard S, Shi X, Castranova V. Changes in bronchoalveolar lavage indices associated with radiographic classification in coal miners. Am J Respir Crit Care Med, 2000, 162: 958-965.

Vanhee D, Gosset P, Boitelle A, Wallaert B, Tonnel AB. Cytokines and cytokine network in silicosis and coal workers' pneumoconiosis. Eur Respir J, 1995, 8: 834-842.

Vanhee D, Gosset P, Marquette CH, Wallaert B, Lafitte JJ, Gosselin B, et al. Secretion and mRNA expression of TNF alpha and LI-6 in the lungs of pneumoconiotic patients. Am J Respir Crit Care Med, 1995, 152:298-306.

Van Landeghem GF, Tabatabaie P, Kucinskas V, Saha N, Beckman G.

Ethnic variation in the mitochondrial targeting sequence polymorphism of MnSOD. Hum Hered, 1999, 49: 190-193.

Van Maanen JMS, Borm PJA, Knaapen A, van Herwijnen $M$, Schilderman PAEL, Smith KR, Aust AE, Tomatis M, Fubin $B$. In vitro effects of coal fly ashes: hydroxyl radical generation, iron release, and DNA damage and toxicity in rat lung epithelial cells. Inhal Toxicol, 1999, 11: 1123-1141.

Van Zee K.I, Kohno E, Rock CF, Moldawer LL, Lowry SF. Tumor necrosis factor soluble receptors circulate during experimental and clinical inflammation and can protect against executive tumor necrosis factor- $\square$ in vitro and in vivo. Porc Natl Acad Sci USA, 1992; 4845-4849.

Viosin C, Wallaert B, Aerts C, Grosbois JM. Broncho-alveolar lavage in coal workers' pneumoconiosis. Oxidant and anti-oxidant 
activities of alveolar macrophages. In: in vitro Effects of Mineral Dusts, Beck EG and Bignon $J$ edited, NATO ASI series, Springer-Verlag Berlin, 1985, Vol. G3, pp. 93-100.

Wagner GR. Asbestosis and silicosis. Lancet, 1997, 349: 1311-1315.

Wagner GR. Screening and surveillance of workers exposed to mineral dust. World Health Organization, Geneva, 1996.

Wallace WE, Harrison JC, Grayson RL, Keane MJ, Bolsaitis P, Kennedy RD, Wearden AQ, Attfield MD. Aluminosilicate surface contamination of respirable quartz particles from coal mine dusts and from clay works dusts. Ann Occup Hyg, 1994, 38: 439-445.

Walker C, Bauer W, Braun RK, et al. Activated T cells and cytokines in bronchoalveolar lavage from patients with various lung diseases associated with eosinophilia. Am J Respir Crit Care Med, 1994, 150: 1038-1048.

Walton WH, Dodgson J, Hadden GG, Jacobsen M. The effect of quartz and other non coal dusts in coal workers' pneumoconiosis. In Inhaled Particles IV (Walton WH, Ed.), Pergamon Press, Oxford, 1977, p669-689.

Walton $\mathrm{WH}$, Dodgson J, Haddon GG, Jacobson M. The effect of quartz and other non-coal dusts in coal workers' pneumoconiosis. Part I: Epidemiological studies. In Inhaled Particles IV, edited by W. H. Walton. Oxford, Pergamon Press. 1977, p669-700.

Wang XR, Christiani DC. Occupational lung disease in China. Int J

Occup Environ Health, 2003, 9:320-325.

Wang YH, Yang Y, Cai LQ. Analysis of prevalence, person-year prevallence and expected incidence of coal workers' pneumoconiosis Ind Hyg Occup Dis, 1990, 16 (1): 11-15.

Wang Z, Mlmerberg P, Larsson K, Palmerberg L. Cytokine production by epithelial cells and macrophage cells following exposure to swine dust. Am J Respir Critc Care Med, 1996, 153: A614.

Wang Z, Malmerg P, Larsson K. Palmerg L. Swine dust induces cytokine secretion from human epithelial cells and alveolar macrophages. Clin Exp Immunol, 1999, 115:6-12.

Warheit DB, Carakostas MC, Harsky MA. Hansen IF. Development of a short-term inhalation bioassay to assess pulmonary toxicity of inhaled particles: comparisons of pulmonary responses to carbonyl iron and silica. Toxicol Appl Pharmacol, 1991, 107: 350-368.

Weill H, Jones RN, Parkes WR. Silicosis and related diseases. In Parkes WR, EDITOR. Occupational Lung Disorders. 3th ed. Butterworths, London. 1994, pp. 285-339. 
Westendorp RGJ, Langermans JAM, Huizinga TWJ, Elouali AH, Verweij CL, Boomsma DI, Vandenbrouke JP. Genetic influence on cytokine production and fatal meningococcal disease. Lancet, 1997, 349: 170-173.

Wilson AG, de Vries N, Pociot F, di Giovine FS, van der Potte LB. Duff GW: An allelic polymorphism within the human tumor necrosis factor alpha promoter region is strongly associated with HLA Al, B8, and D3 alleles. J Exp Med, 1993, 177: 557-560.

Wilson AG, Symons JA, McDowell TL.di Giovine FS, Duff GW. Effects of a tumor necrosis factor (TNF a) promoter base transition on transcriptional activity. Br J Rheumatol, 1994, 33 (Abst): $1: 89$.

World Coal Institute. Coal Facts Card. WCI 2002b, London.

World Health Organization (WHO). Silicosis. Fact Sheet, May 2000.

Yamano Y, Kagawa J, Hanaoka T, Takahashi T, Kasai H, Tsugane S, Watanabe S. Oxidative DNA damage induced by silica in vivo. Environ Res, 1995, 69: 102-107.

Zaidi SH, Bhattacherjee JW, Dogra RKS, Saxena RP. Experimental bagassosis: role of infection. Environ Res, 1983, 31: 279-286. Zhai, R, Liu G, Bao W, Wu C, Yang C, Liang D: Serum levels of tumor necrosis factor-alpha (TNF-a), interleukin 6 (IL-6) and their soluble receptors in coal worker's pneumoconiosis. Respir Med, 2002, 96: 829-834.

Zhang Q, Huang X. Induction of ferritin and lipid peroxidation by coal samples with different prevalence of coal workers' pneumoconiosis: role of iron in the coals. Am J Ind Med, 2002, 42: 171-179.

Zhang Y, Lee TC, Guillemein B, Ming-Chih Y, Rom WN. Enhanced $I L-1 B$ and tumor necrosis factor-a release messenger RNA expression in macrophages from idiopathic pulmonary fibrosis or after asbestos exposure. J Immunol, 1993, 150: 4188-4196.

Zheng C, Huang D, Bergenbrant S, Sundblad A, Osterborg A, Bjorkholm $M$ et al. Interleukin 6 , tumor necrosis factor a, interleukin $1 B$ and interleukin 1 receptor antagonist promoter or coding gene polymorphisms in multiple myeloma. Brit J Haematol, 2000, 109:39-45.

Zhong S, Wyllie AH., Barnes D, et al. Relationship between the GSTM1 genetic polymorphism and susceptibility to bladder, breast and colon cancer. Carcinogenesis, 1993, 14: 1821-1824.

Zou Changqi, Gao Yun, Ma Qingyan. Pneumoconiosis in China: Current situation and countermeasures. In. Mineral dusts and 
prevention of silicosis. Asian-Pacific Regional Network on Occupational Safety and Health Information (ASIA-OSH) vol 4; No. 2, September 1997.

Zhou C, Shen GA. Coal workers' pneumoconiosis in developing nations. In: Occupational Lung Disease. An International Perspective. Banks DE, ParkerJE (eds.). London, Chapman \& Hall Medical, 1998: 183-189. 


\section{ACKNOWLEDGEMENTS}

During this challenging journey in completing my $\mathrm{PhD}$ degree, I am fortunate to have had mentors, colleagues, and friends who provided support to my thesis, to my research, and to my life.

First and foremost, I wish to express my gratitude to my promoter, professor, dr. Jos C. S. Kleinjans, for offering me the opportunity to do Ph.D. study at the Department of Health Risk Analysis and Toxicology (GRAT), Maastricht University. I am forever grateful for his wisdom, advices, supports, and having faith in me.

I am deeply grateful to professor David Christiani who generally supported my studies at Harvard School of Public Health (HSPH). More specifically, I owe my gratitude to Dr. Paul J.A. Borm, Ph.D. and Roel RFP Schins for their guidance and helps when I was studying at GRAT of Maastricht University.

I sincerely thank my colleagues at GRAT of Maastricht University, at HSPH in USA, at Guangxi Institute of Occupational Health (GIOH) in China. I am especially grateful for Dr. Ad Knaapen, Jacco Briedé, and Marcel vanHerijnen for their excellent technicall support and friendship; Dr. Geoffrey Liu, Wei Zhou, Li Su for being an excellent source of scientific advices; Xianmin Ge, Chaoying Wang, Ruiqing Liao, Chuanren Wu, Minmin He for their endless support and friendship to my studies.

The miners are gratefully acknowledged. Without their participation, this study would never have been possible.

I am forever grateful to my family members who have supported me in many ways throughout my many years of study. Finally, I dedicated this thesis to my parents.

I am grateful to all my staff members at GIOH, in GRAT, and Occupational Health Program at HSPH whom I immensely respect for their wisdom, kind helps, and having faith in me. Thanks so much. 


\section{List of Publications}

1. Zhai R, Jetten M, Schins RP, Franssen H, Borm PJA. Polymorphisms in the promoter of the tumor necrosis factor- $\alpha$ gene in coal miners. Am J Ind Med, 1998, 34: 318-324.

2. Zhai R, Liu G, Yang C, Haung C, Wu C, Christiani DC. The G to C polymorphism at -174 of the interleukin- 6 gene is rare in a Southern Chinese population. Pharmacogenetics, 2001, 11 (8): 609-701.

3. Zhai R, Liu G, Ge X, Yang C, Huang C, Wu C, Christiani DC. Genetic Polymorphisms of MnSOD, GSTM1, GSTTI and OGGI in Coal Workers' Pneumoconiosis. J Occup Environ Med, 2002, 44 (4): 372 377.

4. Zhai R, Liu G, Ge X, Bao W, Wu C, Yang C, Liang D. Serum levels of tumor necrosis factor-alpha (TNF- $\alpha)$, interleukin 6 (IL-6) and their soluble receptors in coal worker's pneumoconiosis. Respir Med, 2002, 96: 829-834.

5. Zhai R, Ge X, Li H, Tang Z, Liao R, Zheng Y, Tan J, Liao F. Differences in cellular and inflammatory cytokine profiles in the bronchoalveolar lavage fluid in bagassosis and silicosis. Am J Ind Med, 2004, 46: 338-344.

6. Zhai R, Briedé J, van Herwijnen M.H.M, Maas LM, Moonen EJC,

Zheng Y, Liao R, Ou J, and Kleinjans J. Toxicological features of different coal dusts: possible correlation with prevalence of coal workers' pneumoconiosis. Submitted.

7. Wu S, Shu S, Zhai R, Ge X, Jin T, Bao H, Zhou Y. Lack of therapeutic effect of EDTA on cadmium induced renal dysfunction: A Fourteenyear Follow-up. Biometals, 2004, 17: 435-441.

8. Cui Y, Zhu Y, Zhai R, Chen D, Huang Y, Yi Qiu, Liang J. Transfer of metal mixtures from soil to vegetables in an area near a smelter in Nanning, China. Environ Internal, 2004, 30: 785-791.

9. Kline JN, Doekes G, Bonlokke J, Hoffman HJ, Essen SV, Zhai R.

Working Group report 3: sensitivity to organic dusts-atopy and gene polymorphisms. Am J Ind Med. $2004 \mathrm{Oct} ; 46$ (4): 416-8.

10. Zhai $\mathrm{R}$, Cai $\mathrm{L}$, Muo $\mathrm{C}$. The application of nasal lavage in occupational and environmental medicine. Chin J Prev Med, 1998, 32 (6) : 378-379.

11. Zhai R. Biomarkers of occupational exposure to polycyclic aromatic hydrocarbons. Chin Occup Med, 2000, 27 (3) : 43-45. 12. Zhang H, Li Y, Yan S, Lei Z, Zhai R, Wu C. Evaluation of FPD, Ddimer and other biochemical indexes in early diagnosis of silicosis. Chin Occup Med, 2000, 27: 19-20.

13. Zhai $R$, Chen $T$, Chen $X$, et al. Effects of chlorine exposure on 
oxidative indices in nasal lavage fluid. Chin Occu Med, 2002, 29 (2) : 24-25.

14. Zhai $R$, Chen $T$, Chen $X$, et al. Effects of chlorine exposure on inflammatory markers in nasal lavage fluid. Chin J Ind Med, 2002,3: 176-178.

15. Chen X, Chen T, Jiang S, Shu S, Zhou S, Zhai R. Effects of lead and arsenic on the exchange rate of chromatid in lymphocytes: Chin $J$ Ind Med, 2003, 16: 206-208.

16. Chen $X$, Chen $T$, Gan $Y$, Zhai $R$, Jiang $S$. in vitro Effects of lead, arsenic, and benzene exposure on chromosome damages in lymphocytes. Guangxi Prev Med, 2003, 9: 136-138.

17. Chen X, Chen $T$, Jiang $S$, Zhou S, Gan Y, Zhai R. Chromosome damages by arsenic in cultured human lymplnocytes. Chin J Ind Hyg Occup Dis, 2003, 21: 231.

18. Chen X, Zhou S, Shu S, Zhai R. Chen T, Gan Y. Relationships between metal exposure levels and Chromosome abnormal types. $J$ Health Toxicol, 2003, 17: 176-177.

19. Cui $Y$, Zhu $Y$, Zhai $\mathbb{R}$, Chen D, Huang $Y$, Qiu Y, Liang J, Deng S. Exposure to metal mixtures and human health impacts in a contaminated area in Nanning, China. Environ Intern (in press).

20. Chen $X$, Chen T, Zhai R, et al. Study on the cytogenetic toxicities in aluminum electrolytic workers. Guangxi Prev Med, 2003, 9: 198-200.

21. Li A, Long F, Zhai R. An investigation on pneumoconiosis prevalence in a smelter. Occup Health, 2002, 18: 12-13.

22. Li Y, Zhang HY, Yuan XL, Lei LZ, Wu CR, Zhai R. Exploration on early diagnostic significance by the level of fibrin degradation product (FDP), D-Dimer in silicosis patients. J Guangxi Med Uni. 2000, 17 (1):1-2.

\section{Abstracts:}

1. Zhai R, et al: TNF- $\alpha$ polymorphisms in ex-coal workers with and without coal worker"s pneumoconiosis. Eur Respir J, 1997, 10.suppl: $234 \mathrm{~s}$.

2. Zhai $R$, et al: Serum levels of TNF- $\alpha$ and its soluble receptors in coal worker's pneumoconiosis: correlation with oxidative markers. $26^{\text {th }}$ International Congress on Occupational Health, 2000, Singapore, PS4: 82 .

3. Ge X, Zhai R, et al: Serum levels of IL-6 and its soluble receptors in coal worker's pneumoconiosis. $26^{\text {th }}$ International Congress on Occupational Health, 2000, Singapore, PS4: 82.

4. Zhai $R$, et al. Effects of chlorine exposure on oxidative indices in nasal lavage fluid. Proceedings of the Seventh National. Conference on 
Occupational Health, September 2001, Chengdu, China, P. 225

5. Buo W, Lu Z, Su D, Zhai R, et al Pesticide poisoning in Guangxi, P. R. China (1995-1996). 2000 Industrial Health Conference, A pril 1-2, 2000, Taipei, P. 259.

6. Zhai $R$, et al. Serum levels of TNF- $\alpha$ and its soluble receptor 555 and p75 in coal miners. 2000 Industrial Health Conference, April 1-2, 2000, Taipei, P. 148.

7. Chen XQ, Chen TT, Shu SH, Zhai R, Zhou SS, Gian YJ. Effects of lead, arsenic, and cadmium exposure on chromatid exchange rates in human lymphocytes. $5^{\text {th }}$ Congress of Toxicology in Developing Countries, Guilin, China, Nov. 10-13. 2003. 


\section{Curriculum Vitae}

\section{Awards and Honors}

(1). National Scholarship (Education Ministry of China, 1996).

(2). Grant recipient (Project: Cytokine polymorphisms in miners with silicosis, 1998).

(3). Grant recipient (Project: Genetic polymorphisms of antioxidants in coal workers' pneumoconiosis, 1998).

(4). Grant recipient (Project: Biomarkers in nasal lavage fluid in chlorineexposed humans, 1999).

(5). Fogarty Research Fellowship from NIH (USA, 2000).

(6). Grant recipient (Project: Airways inflammation in workers exposed to bagasse dust, 2003)

(7). Editor, China Occupational Medicine.

(8). Deputy Director, Occupational Medicine Association of Guangxi Province, China

(9). Deputy Director, Guangxi Institute of Occupational Health \& Guangxi Worker's Hospital, China.

(10). Fogarty Research Fellowship from NHH (USA, 2004).

(11). Science and Technology Progress Award (Guangxi Government, China, 2004).

\section{Education}

1978-1983

Guangxi Medical University, China, M.D;

1988-1991

Guangxi Medical University, China, M.Sc., Medicine;

$1997-2005$

Maastricht University, PhD candidate, The Netherlands.

\section{Professional Experiences}

$02 / 2005$

Research Fellow, Occupational Health Program, Harvard School of Public Health, USA.

01/1999-01/2005 Deputy director, Chief doctor, Guangxi Institute of Occupational Health \& Guangxi Worker's Hospital, Guangxi, China.

09/2000-03/2001 Research Fellow, Occupational Health Program, Harvard School of Public Health, USA.

09/1996-11/1997 Visiting Scholar, Dept. of Molecular Biology, Wageningen Agriculture University, The Netherlands; Dept. of Health Risk Analysis and Toxicology, Maastricht University, The Netherlands.

08/1983-08/1996 Physician, Associate Chief, Head, Division of 
Occupational Health, Health \& Anti- epidemic Station of Beise / Nanning prefecture / Guangxi Province, China. 


\section{Abbreviations}

AAS Atomic absorption spectrometry

AM Alveolar macrophage

BAL Bronchoalveolar lavage

BALF Bronchoalveolar lavage fluid

bp Base pair

BPE Bovine pituitary exiract

CAT Catalase

CWP Coal workers" pneumoconiosis

dG 2" deoxyguanosine

DMPO 5,5-dimethyl-1-pyrroline-N-oxide

DMSO Dimethyl sulfoxide

EDTA Ethylenediaminetetraacetic acid

ELISA Enzyme-linked inmunosorbent assay

ESR Electron spin resonance

GPX Glutathione peroxidase

GST Glutathione-S-transferase

HPLC High perfomance liquid chromatography

IL Interleukin

ILO International Labour Office

LPS Lip polysaccharicle

MnSOD Manganese superoxide dismutase

MTT 3-(4,5-dimethylthiazol-2-yl)-2,5-diphenyltetrazolium bromide 


\begin{tabular}{|c|c|}
\hline NQOI & Quinone reductase \\
\hline OGG1 & 8-oxoguanine DNA glycosylase \\
\hline PBS & Phosphate buffered saline \\
\hline PCR & Polymerase chain reaction \\
\hline PMF & Progressive massive fibrosis. \\
\hline 8-oxo-dG & 7-hydro-8-oxo-2'-deoxoguanine \\
\hline $\mathrm{rEGF}$ & Recombinant epidermal growth factor \\
\hline RIA & Radioimmunoassay \\
\hline $\operatorname{ROS}$ & Reactiwe oxygen species \\
\hline $\mathrm{SD}$ & Standiard deviation \\
\hline SNP & Single nucleotide polymorphism \\
\hline $\mathrm{SP}^{\prime}$ & Simple pneumoconiosis \\
\hline TGF $-\beta$ & Transforming growth factor $\beta$ \\
\hline TNF & Tumor necrosis factor \\
\hline STNF-R & soluble tumor necrosis factor receptor \\
\hline sIL-6R & soluble interleukin 6 receptor \\
\hline & al transition metal \\
\hline
\end{tabular}

